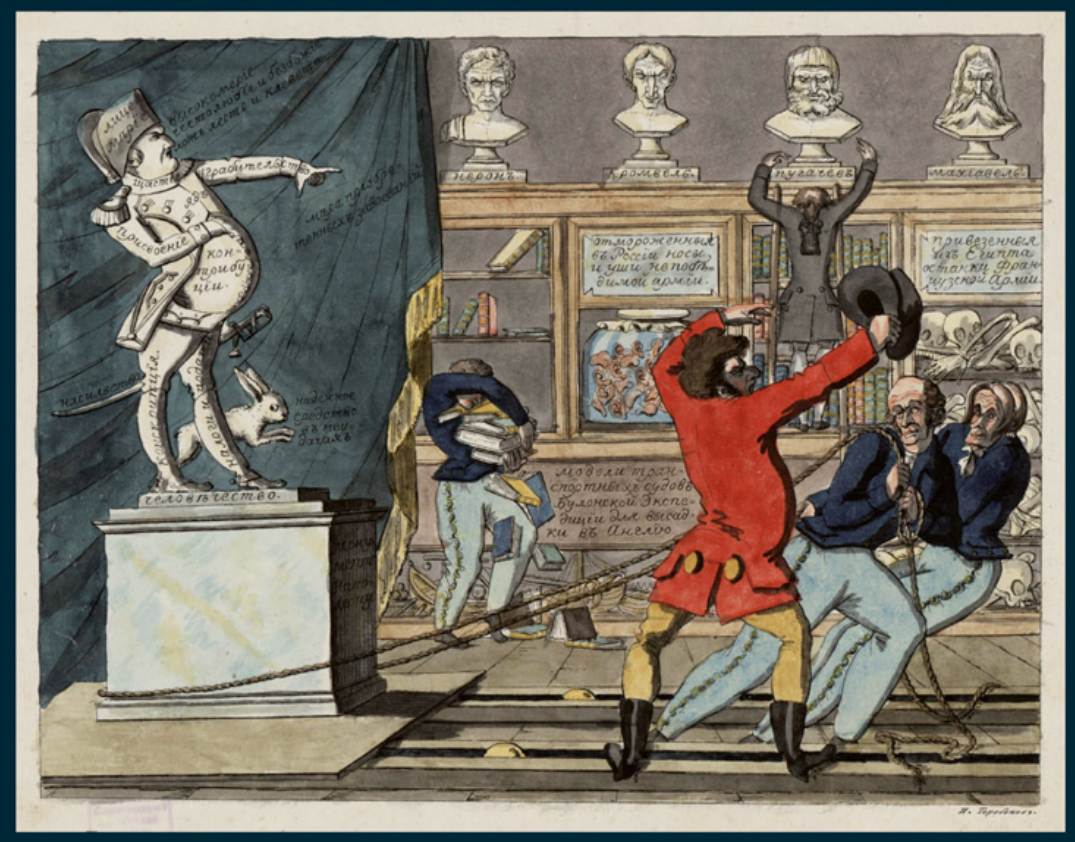

Elisabeth Cheauré, Regine Nohejl (eds.)

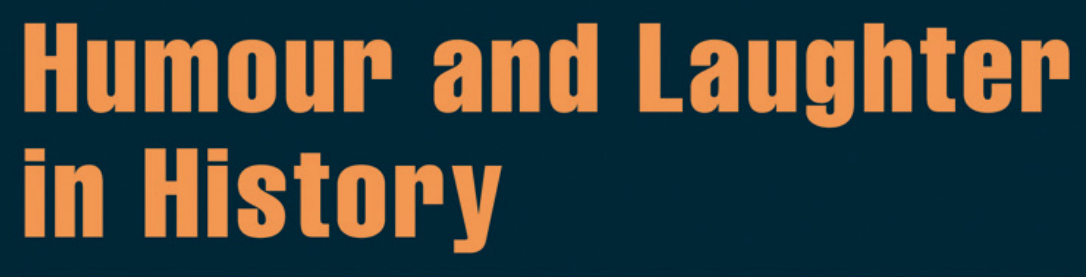

Transcultural Perspectives

[transcript] History in Popular Cultures 
Elisabeth Cheauré, Regine Nohejl (eds.)

Humour and Laughter in History

Historische Lebenswelten in populären Wissenskulturen History in Popular Cultures I Volume I5 


\section{Editorial}

The series Historische Lebenswelten in populären Wissenskulturen | History in Popular Cultures provides analyses of popular representations of history from specific and interdisciplinary perspectives (history, literature and media studies, social anthropology, and sociology). The studies focus on the contents, media, genres, as well as functions of contemporary and past historical cultures.

The series is edited by Barbara Korte and Sylvia Paletschek (executives), HansJoachim Gehrke, Wolfgang Hochbruck, Sven Kommer and Judith Schlehe. 
Elisabeth Cheauré, Regine Nohejl (eds.)

\section{Humour and Laughter in History}

Transcultural Perspectives

[transcript] 
Our thanks go to the German Research Foundation (Deutsche Forschungsgemeinschaft) for supporting and funding the project.

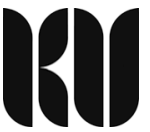

An electronic version of this book is freely available, thanks to the support of libraries working with Knowledge Unlatched. KU is a collaborative initiative designed to make high quality books Open Access for the public good. The Open Access ISBN for this book is 978-3-8394-2858-o. More information about the initiative and links to the Open Access version can be found at www.knowledgeunlatched.org.

\section{(c) $(1)(9)$}

This work is licensed under the Creative Commons Attribution-NonCommercial-NoDerivatives 4.0 (BY-NC-ND) which means that the text may be used for non-commercial purposes, provided credit is given to the author. For details go to http://creativecommons.org/licenses/by-nc-nd/4.o/

To create an adaptation, translation, or derivative of the original work and for commercial use, further permission is required and can be obtained by contacting rights@ transcript-verlag.de

Creative Commons license terms for re-use do not apply to any content (such as graphs, figures, photos, excerpts, etc.) not original to the Open Access publication and further permission may be required from the rights holder. The obligation to research and clear permission lies solely with the party re-using the material.

\section{(C) 2014 transcript Verlag, Bielefeld}

\section{Bibliographic information published by the Deutsche Nationalbibliothek}

The Deutsche Nationalbibliothek lists this publication in the Deutsche Nationalbibliografie; detailed bibliographic data are available in the Internet at http://dnb.d-nb.de

\section{Cover layout: Kordula Röckenhaus, Bielefeld}

Cover: Parižskogo Muzeja po slucöaju približenija Sojuznych Armij, http://dlib. rsl.ru/01005113610, »Bei der eingehenden Besichtigung der Krupp'schen Kanone soll der Kaiser stellenweise ganz weg gewesen sein.«

Karikatur aus »Kladderadatsch«, Nr. 27, 16.6.1867 [Photo Regine Nohejl] Printed by Majuskel Medienproduktion $\mathrm{GmbH}$, Wetzlar

Printed by Majuskel Medienproduktion $\mathrm{GmbH}$, Wetzlar

Print-ISBN 978-3-8376-2858-6

PDF-ISBN 978-3-8394-2858-0 


\section{Contents}

\section{Introduction}

Elisabeth Cheauré/Regine Nohej1| 7

Napoleon and the 1812 Patriotic War

in Russian Humour

Elisabeth Cheauré | 15

Alfred and Friedrich Alfred Krupp as Butt of Jokes?

The German Perception of the Economic Elite in the $19^{\text {th }}$ Century

Axel Heimsoth | 33

\section{Letting Loose the Doggerel of War}

Humorous and Satirical Journals in Britain,

France and Germany 1914-1918

Lesley Milne 59

\section{Poignant Past}

How Interwar Satirical Magazines in Germany,

France and Spain Used History to Criticise

Their Times

Louisa Reichstetter | 79

More than Resistance: Political Humour

Under Stalin in the 1930s

Jonathan Waterlow | 103

"Then We Will Fight in the Shade «

Sparta, Comedy and Coming to Terms with the

Fearsome Otherness

Sabrina Feickert | 119

Authors and Editors | 137 



\section{Introduction}

ELISABETH CHEAURÉ/REGINE NOHEJL

The present volume is the continuation and supplementation of the anthology »History \& Humour. British and American Perspectives «, which Barbara Korte and Doris Lechner published at transcript publishing house in 2013. Both volumes are the result of the work of the DFG research group »History in Popular Cultures of Knowledge«, which has, for the past several years, been meeting at the University of Freiburg to discuss the phenomenon of popularizing history and bringing it »up to date «.

At first glance the contributions here seem very heterogeneous. The settings range from the U.S. to Europe to Russia, covering a chronological period from 1800 to the present. However, on closer inspection, a surprising number of similarities become clear. If humour comes into play in dealing with history, it is almost always when coping with the most serious, even threatening situations: violence, terror, war, social, political and psychological tensions of all kinds appear to be the preferred subjects for humorous arrangement. Even if the scope of this anthology does not permit representative statements, it is remarkable that five of the six contributions discuss events that were in the present for the people concerned, i.e. humour is primarily activated in dealing with their own »story « and experiences of the world. Even in places where use is made of eras and traditions far in the distant past, it is always accompanied by a discourse about understanding one's own self. The popular-humorous approach to history may therefore be able to illustrate the profoundly constructivist or functionalist character of any interest in history: history is never researched just for its own sake; it is always additionally a means to deal with and interpret one's own present.

Another feature of the humorous turn to history, which is clearly expressed in this volume, is the preference for combining the verbal with the visual: images are often able to express humorous elements better and more concisely than words. On the other hand, the connections are usually too complex to manage without any verbal remarks at all.

Barbara Korte and Doris Lechner, of whose competent analysis of researching laughter and humour in different disciplines and at different times this anthology makes use, distinguish three basic functions of humour and laughter (cf. Korte/Lechner 2013: 11-13): 
- The structural: humour serves to defuse »ridiculous « situations and incongruences caused by the divergence of event and expectation or by a clash of expectations;

- The psychological: humour is a means of reducing tension, insecurity, anxiety;

- The social: humour is an important part of social communication: one does not laugh alone. »Bergson was right when he wrote that the comic aspects of human life can hardly be experienced in isolation. Laughter requires an echo [...]. Indeed, a passenger on a bus or sub-way, obviously travelling without a companion, does frighten us slightly if he or she suddenly bursts into laughter, or grins without interruption. « (Zijderveld 1983: 3).

It is understood - and is indeed also supported by the following contributions - that the three components mentioned above overlap frequently. Equally, when talking about laughter and humour, the anthropological and the historical component cannot be separated. The ability to laugh is undoubtedly an anthropological constant; however »das Lachen [verweist] nicht nur auf endogene seelische und geistige Zustände, sondern darüber hinaus auf die sie induzierenden extrasubjektiven Gegenstände, Situationen und Vorgänge « (Fietz 1996: 14) The specific form of the humorous thus always remains bound to particular historical conditions and constellations.

When invoking Mikhail Bachtin's thoughts on the carnivalesque (cf. Bakhtin 1968), it is often pointed out that the central feature of humour lies in its subversive function; that its use is favoured in questioning a prevailing system or even toppling it. In fact, humour is often based on a game with fixed, mechanized habits of speech, thought and life (cf. Zijderveld 1983: $10 \mathrm{ff}$., 17ff.), which it breaks open, raises awareness of and thereby potentially questions. Humour does have a playful, communicative nature but it is not per se a means of subversion, and also does not automatically imply a call for »thinking differently«, for more tolerance and understanding. Laughter and humour as character codes in the range of intersubjective communication cover »die gesamte Bandbreite von heiter-geselligen über kritische bis zu höhnisch-feindlichen Ausdrucksformeln « (Fietz 1996: 15), and they can consequently be used likewise to »zwischenmenschliche Beziehungen anzubahnen, auf Distanz zu halten oder gar auseinanderzubrechen zu lassen « (ibid.). The general constituent of humorous situations seems to be the need for some kind of »recognition « of the »strange « (cf. Scholz Williams 1996: 82): an »Other «, a counterpart - be it a situation, a person, a group, etc. - is constructed in such a way as to take away its horror and strangeness. This can take a symmetrical form: both sides find each other through common, 
redemptive laughter; but it may just as well happen in an asymmetrical manner: the laughter becomes laughter at the other, with all the scorn, ridicule, devaluation and degradation this implies. This works better the more selfassured and superior the other previously appeared (key word: schadenfreude; cf. Zijderveld 1983: 39). Humour thus proves itself a tool that can be used in diametrically opposing ways: for the propagation of tolerance as well as intolerance, in the hands of rulers and of the oppressed, in stabilising as well as criticising the system. The strategies used in each case are of course quite different from each other. The contributions in this volume provide a good insight in-to the variety of such strategies.

In the area of social and historical macro-structures, laughter at another party seems to occur much more frequently than shared laughter. An even rarer occurrence on this level - Goethe's epigram »Wer sich nicht selbst zum besten haben kann, der ist gewiss nicht von den Besten« aside - is humour as a means of self-criticism and self-relativization. To be able to laugh in existentially relevant situations at oneself requires either a very stable identity or desperate self-abandonment (so-called gallows humour): the former is rare in history's biggest civilizations, and the latter, the state of anomie, is so dangerous for larger social groups that it is avoided wherever possible. In the field of history, humour usually thus expresses itself on the »middle« level, in laughter at another party, which is used as a foil in order to stabilize an own identity, but without completely dismantling the other. This is a balance of power which allows better control of the inevitable potential for conflict. However, the following contributions also show how precarious this balance is and how quickly the situation can escalate and flip into a literally »crushing $\ll$ laughter.

ELISABETH CHEAURÉ's article deals with the role of humour in Russia's Patriotic War against Napoleon (1812). The confrontation with Napoleon has been crucial for the development of Russian national identity and its positioning relative to Western Europe. Although Napoleon remains a cult figure for some of the Russian intelligentsia, after 1812 the victory over him became the prototype of an ever-repeating pattern; a kind of stylized historical regularity: Russia is in its moral integrity always proven victorious over the aggressive and arrogant western invaders who wrongly consider themselves superior; Russia ultimately becomes the »saviour « of Europe - a narrative that is still effective today. In the $19^{\text {th }}$ century, it became popularized in humour in the form of jokes and anecdotes, but especially - and not surprisingly given the widespread illiteracy - in visual media. So-called 
lubki, simple lithographs, were distributed en masse. The lubki, which greatly contributed to the development of caricature in Russia and also for the first time contained representatives of the common people emerging as heroes, used characteristic strategies of devaluation and ridicule of the enemy. The superiority of the simple Russian people, collectively acting in solidarity against the selfish westerners in power, is demonstrated. The enemy is dehumanized (e.g. with animal metaphors) and subjected to degrading gender changes (feminization). The feeling of schadenfreude is used most effectively when exactly those defects of which »uncivilized « Russia is accused (indifference, sloppiness, etc.) are proven to be effective weapons in the fight against the civilized and seemingly vastly superior enemy, France - a country which provided the dominant culture for Russia in the $18^{\text {th }}$ century.

AXEL HeIMSOTH uses examples of well-known German magazines of the $19^{\text {th }}$ century to illustrate the changing public reputation of Alfred Krupp and his son Friedrich Alfred, as reflected - and indeed produced and established - in the popular genre of caricature. The man who, in the 1860s, was effusively celebrated in magazines such as Kladderadatsch and Die Gartenlaube as »King of the Guns «, able to protect and benefit his country better than the lawful kings, undergoes a significant image towards the end of the $19^{\text {th }}$ century. In the context of increasing social tensions and the strengthening of the social democratic movement (Ulk, Der wahre Jakob) Friedrich Alfred Krupp tends to be portrayed as an unscrupulous capitalist, even a »demon «, who sells his arms to anyone who has the money - even to Germany's enemies. Caricature increasingly becomes a »weapon « wielded against the weapons manufacturers. Krupp flees from public hostility to his home on Capri. He dies in November 1902, after the Vorwärts published an article about his alleged homosexual relations with young men on Capri. There are rumours of a suicide. Even the demonstrative solidarity of William II with the Krupp family and company does not change anything. It is not until the First World War that the success of new Krupp weapons temporarily triggers another new mood; a kind of collective hysteria and enthusiasm; and the criticism, which becomes louder in the course of the war, never again returns to such extreme forms as in the case of Friedrich Alfred Krupp.

LESLEY MILNE turns to the genre of doggerel and comparatively investigates how it was applied in English, French and German satirical magazines (Punch, Le Rire and Simplicissimus respectively) during the First World War. In 1914 all three magazines are, regardless of their critical traditions, 
supporters of the war and mouthpieces of public propaganda. At the same time, each legitimises its own country's involvement as »defensive «. Humour is used to represent the enemy as weak and ridiculous and thereby to demonstrate one's own superiority. The social function of collective patriotic mobilization clearly combines here with the psychological function of humour: the displacement of individual fears and insecurities. Each magazine develops its own form of »threats «. A popular old tradition, for example, was »flyting «, a boast-insult-contest in which one concedes the skills and achievements of one's opponent, yet at the same time appears completely unimpressed by them. Milne names Herodotus' story as a classic example: at the battle of Thermopylae a Spartan soldier laconically answers to the threat that the arrows of the Persian opponents would darken the sky, »Then we shall fight in the shade « (Sabrina Feickert also references this episode in her contribution). A similar effect is achieved, for example, when Le Rire reported that the Germans had indeed placed their flag on Antwerp Cathedral, but it would not stop the weather vane going about his business in the usual manner. Another possibility of such tactical understatement is realized by pretending to accept victories as well as defeats calmly and indifferently, in contrast to one's opponent. By referring to one's serene, dignified manner, defeats and setbacks can be reconstrued as »victories «. Milne concludes that the type of humour is less dependent on national peculiarities than on particular circumstances and constellations.

LOUISA REICHSTETTER comes next in the chronological order with a comparison of German, French and Spanish satirical journals in the period between the world wars. All magazines examined are attributable to the liberal and left wings. Their goal is primarily the defence and legitimization of the interwar republics, which were very weak in Germany and Spain. In connection with this, historical traditions and metaphors are often referred to, in both affirmative and negative ways. The French Revolution is a key historical image referenced not only in France; and the Phrygian cap of the Jacobins, for example, has a metaphorical function, where its physical state is used to simultaneously indicate the state of each existing Republic. Over time, the references to the French Revolution become more diverse and distinct; they shift from the visual to the verbal. The arrogance of the French Prime Minister Poincare is commented on via the annotation »Les taxes c'est moi,« thereby connecting him with the Ancien Régime. Kurt Tucholsky mocks the lack of political action on the part of Germans, whose political will to change fails due to their love of order and deference to au- 
thority, by allowing that a German revolution did take place - but by necessity »in music «. Negative historical references in Germany mainly use the Kaiserreich (Empire), whose legacy in Hindenburg's election to the presidency hangs like a millstone around the neck of the Weimar Republic. France's other cautionary example next to the Ancien Régime is, interestingly, Napoleon Bonaparte's unbridled thirst for power.

JONATHAN WATERLOW's contribution dives right into the middle of the world of subversive humour as described by Mikhail Bachtin. Based on extensive archival material, the author examines forms of political humour in the Soviet Union of the 1930s. Humour is used here as a highly elaborate weapon against the extreme fears, constraints and uncertainties with which the individual is faced in the Stalinist regime of terror. Whether humour can be described as a form of resistance remains open to question. As a rule, no independent oppositional political objectives are formulated via humour; rather, a subtle game is played with the political status quo, especially in regard to its linguistic expressions (propaganda, slogans, etc.). By simply transferring them to other, everyday contexts, their absurdity and distance from reality is demonstrated. Also popular is the reinterpretation of abbreviations, whose use in the Soviet Union took on inflated proportions; thus SSSR (Sojuz sovetskich socialističeskich respublik / Union of Soviet Socialist Republics) becomes »Smert' Stalina spaset Rossiju « (Stalin's Death [Smert'] will Save Russia). The devastating, self-propelling effects of the regime of terror are apparent in a joke about a schoolboy who, responding to a teacher's question as to who had written Evgenij Onegin (one of the most famous $19^{\text {th }}$ century Russian novels), answers in panic, $»$ Not me $\ll$. His parents eagerly confirm to the appalled teacher that their son had not written the work; the NKVD interrogates the family and finally receives the answer that they had all written Evgenij Onegin together. According to Waterlow, there was a kind of diglossia of the Russian and the »Soviet« in the Soviet Union of the 1930s. In this way everyone lived in different worlds linguistically and with different masks that had to be combined in a more or less virtuoso manner. Interestingly, these worlds were not strictly separate, but, like crosshatching, often superimposed on and interacted with each other.

SABRINA FEICKERT shows how ancient historical events and myths are used in the present in order to categorize and cope with the terrifying Other. The clash of Spartans and Persians at Thermopylae in 480 BCE, described by Herodotus, has gained unexpected popularity through the Zack Snyder film 
300 (USA, 2007). The film conducts an unrestrained aestheticization of violence, while skirting any discursive tendencies, let alone irony and humour - unlike, say, the films of Quentin Tarantino. Ironic sequences, for example, the famous laconic Spartan answer, »Then we will fight in the shade « to the threat of Persian arrows darkening the sky, serve to mock one's opponent, but not to question oneself. The film simplistically presents two irreconcilable, opposing worlds: the mercilessly rational, highly organized, strictly heterosexual order of Spartan society and their king Leonidas, against the immense tide of faceless, monstrous Persian combatants under Xerxes, whose dubiousness and inferiority is largely communicated by gender characteristics. The King of Persia is characterized as a sexually ambiguous being, a transvestite. 300 is clearly to be understood as a production (dressed up in ancient costume) about the current »clash of civilizations «; the supposed »threat« to Western civilization from archaic, vindictive, unpredictable cultures. Feickert refers inter alia to the obvious similarities between Leonidas' pronouncements and George Bush's »rhetoric of liberty«. Even more interesting than the film itself, and bringing humour into play, is the fact that 300 has given rise to a flood of parodies (two examples Feickert examines are Jason Friedberg's Meet the Spartans and the South Park episode »D-yikes«), which also prefer to work on the level of gender. By questioning and resolving the heterosexual norms of the Spartans, which seem so unassailable in the film, their entire behaviour is thrown into doubt. The inflationary use of slogans such as the famous »This is Sparta!« in every conceivable - appropriate and usually completely inappropriate - context leads once again to 300's message being not affirmed, but irredeemably pulled apart.

At this point we would like to express our gratitude to all the authors whose articles have contributed to readers discovering interesting news from the world of history, and especially in such a critical, instructive and entertaining way. A big thank you also goes to Kate Fletcher, who has carefully proofread all contributions written by non-native English speaking authors and has been an invaluable source of support to the editors (who are both professionals in Slavic Studies rather than English) in all questions of English wording. We would also like to articulate our affinity with our colleagues in the research group »Historische Lebenswelten« and express our thanks for three years of joint work on very different historical topics, something that has widened all of our horizons. Last but not least we would like 
to thank transcript publishing house in Bielefeld for their willingness to accept the present volume in their publishing program.

Freiburg, May 2014

The editors

\section{LITERATURE}

Bakhtin, Michail 1968: Rabelais and His World, Cambridge: M.I.T. Pr.

Fietz, Lothar 1996: »Möglichkeiten und Grenzen einer Semiotik des Lachens «. In: Lothar Fietz, Joerg O. Fichte, Hans-Werner Ludwig (eds.): Semiotik, Rhetorik und Soziologie des Lachens. Vergleichende Studien zum Funktionswandel des Lachens vom Mittelalter zur Gegenwart, Tübingen: Niemeyer, 1996, 7-20.

Korte, Barbara/Doris Lechner 2013: »History and Humour. Charting the Field«. In: Barbara Korte/Doris Lechner (eds.): History and Humour. British and American Perspectives, Bielefeld: transcript, 7-20.

Scholz Williams, Gerhild 1996: »Das Fremde erkennen: Zur Erzähltheorie des Lachens im Mittelalter und in der Frühen Neuzeit«. In: Lothar Fietz, Joerg O. Fichte, Hans-Werner Ludwig (eds.): Semiotik, Rhetorik und Soziologie des Lachens. Vergleichende Studien zum Funktionswandel des Lachens vom Mittelalter zur Gegenwart, Tübingen: Niemeyer, 82-96.

Zijderveld, Anton C. 1983: »The Sociology of Humour and Laughter«. In: Current Sociology / La sociologie contemporaine 31/3. 


\section{Napoleon and the 1812 Patriotic War in Russian Humour}

ELISABETH CHEAURÉ

There are few events in Russia's history that have anything like the significance of the war against Napoleon, the famous battle of Borodino and the subsequent Fire of Moscow, with its surrounding myths.

This evaluation may seem surprising, at least from a Western perspective. One would perhaps regard the accession of Peter the Great, or the October Revolution in 1917, or the Second World War as particularly important events. So why 1812? And why a battle that only lasted one day in early September 1812, and from which no clear victor emerged, but which instead cost umpteen thousand lives on both sides and thus can rightly be called one of the bloodiest battles of the $19^{\text {th }}$ century?

A brief reminder: Both Napoleon's Grande Armée and General Field Marshall Kutuzov's Russian Army claimed the battle as a victory. Napoleon marched on towards Moscow, but his desire to start negotiations fell on deaf ears. Instead, he found himself in the looted, burning city of Moscow, and with the start of an unusually early winter, he was soon in a catastrophic supply situation. The retreat of the Grande Armée was a complete disaster with few survivors. In a second legendary battle, the Battle of Berezina, Napoleon suffered his final defeat. This military defeat was followed soon after by political defeat, and Napoleon was banished to Elba.

The events of 1812 were commemorated in grand style and with great expense at the centenary celebrations in 1912. But not just in 1912. In 2012 the bicentenary in Russia was also lavishly marked. The preparation of the celebrations had been going on for several years under the direction of a special state commission, set up exclusively for this purpose at the behest of the highest government circles. The culmination of their efforts came at the end of August and the beginning of September. Two of the highlights of the celebrations, which extended over the whole country, can be called representative for the many hundreds of events because of their particular importance. The first is the ceremony on the battlefield of Borodino on 2 September, celebrated by President Putin. Over 2,000 people from home and abroad actively participated in the subsequent reenactment (rekonstrukcija), and several hundreds of thousands of spectators attended. The second is the 
grand opening of the Museum of the 1812 War (Muzej vojny 1812 goda), which was opened on 4 September as part of the State Historical Museum (GIM). With this museum, plans that had already been drafted for the anniversary in 1912 finally became reality.

Not only these measures, but many other past and present media (such as memorials, panoramas, movies, TV series, children's books, school books to name but a few examples) can be grouped under the heading »popularisation of history «. One of the many forms of »popularised history « can undoubtedly be found in medial representations that are linked in a broad sense to the phenomenon of laughter: humour, satire, ridicule, be it in verbal (e.g. jokes) or visual (e.g. cartoon) form.

This process of popularisation is the main subject of our research project, which looks at the hype surrounding 1812 from a particular angle, namely to find an answer to the question: To what extent can this discourse be functionalised to serve the process of creating national identity? ${ }^{1}$

At first glance, Napoleon and the 1812 War seem to be a very serious matter, even an affair of the state. This is not surprising, given the huge number of victims. So what roles can laughter and humour play in relation to a figure like Napoleon, who as Čerepanova put it, went from being the epitome of >the enemy< to a key figure in Russia's national identity? Is there a counterdiscourse of laughter, as understood by Bachtin? What types of texts had the most powerful effect? Why was it Napoleon, in particular, who became a figure in Russian culture known to every single Russian child? And what is behind this sentence taken from a collection of Napoleon jokes on the Internet?

To Russian ears it sounds funny because the sentence has a structure which is not logical in the first place.

»Napoleon's legacy in Russia: cake, cognac, crackpots.«

To explain to those who are not so familiar with Russian culture: there is a delicious cake called `Napoleon`, a cognac of the same name, and most

1 At this point I would like to thank the project group including Regine Nohejl, Marina Kahlau and Konstantin Rapp for the many valuable stimuli they gave me for this paper, which should be seen as a joint achievement. 
Napoleon jokes in Russia these days have something to do with lunacy. Here is a typical example:

»Two lunatics are talking about a third lunatic: Did you hear that Napoleon has gone completely crazy. He thinks he is a cake.«

However, in my paper I will not confine myself to the present or to jokes that are a play on words. I would like to go further back into the past, in particular to the period of Napoleon and its accompanying pictorial material. Before inviting the reader on a short journey through Russian humour, I should formulate a couple of premises:

In the $19^{\text {th }}$ century and extending right up to the most recent past, all written publications and images were under scrutiny from censors - first czarist, then religious, and later Soviet censorship. The situation today is more complex because censorship is less evident. The absence of freedom of the press always has to be taken into account. In view of these conditions, oral discourse is of great significance. To begin with it was the rural folk tradition that was a rich source of Russian jokes or anekdoty as they are called in Russian, but in the $20^{\text {th }}$ century joke collections and of course the Internet provide us with what can be called urban folklore. These anekdoty are usually brief, potentially satirical, anonymous, taboo-breaking, usually structured in three segments, sometimes politically subversive, sometimes sexualised, sometimes simply referring to everyday life, and sometimes they play with double semantics, like the pun about Napoleon and the cake.

When I talk of pictorial material, I am referring to a particular tradition that also needs some explanation. I am talking about so-called lubki (singular is lubok, lubočnaja kartina), which have a very special significance within popular Russian culture. They constitute a pictorial tradition that came into existence in the course of the $18^{\text {th }}$ century in Russia, and which was recognised by Peter the Great as a political instrument because of the potential for conveying information and propaganda. The lubki initially served to pass on information, in particular information as put out by the State, but they were very soon used for satire and thus as a way of criticising the State. They are usually simple prints, taken from woodcuts, and then strongly coloured. Some researchers (e.g. Bowlt 1983: 222) have found similarities with German pamphlets and English broadsheets. Aesthetically they appear unsophisticated and somewhat naïve in their approach. The latter quality was at times deliberately cultivated, for example when an alphabet with jingles referring to the war was published. 
The following example (Fig. 1) comes from a collection of cartoons entitled Azbuka (»Alphabet. A gift to children in memory of the year 1812 for the instruction of descendants «) that appeared in 1814, after the war. There are 34 sheets from the artists Terebenev, Ivanov and Venecianov.

Figure 1: I.I. Terebenev: Azubka, letter č (1814) »What else can I do! It's time to respect the pig's kindness; there's no horses! Time to drive a pig."

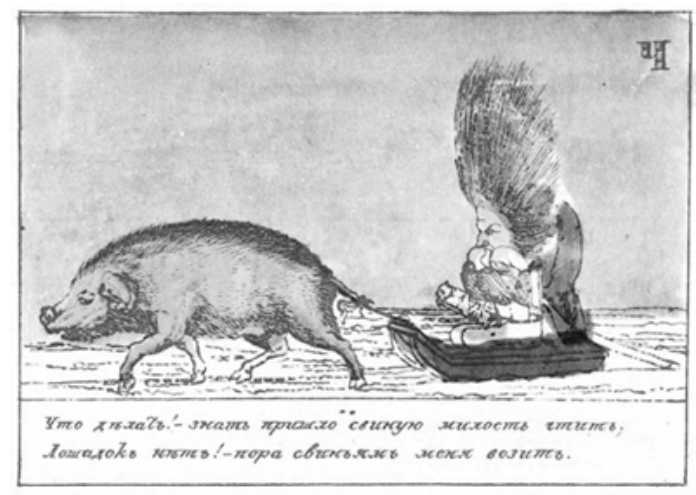

Source: <http://statehistory ru/2052/Detskaya-azbukapro-voynu-1812-goda--izdannaya-v-1814-godu/>

Also typical is the combination of pictorial and text elements, which remind one a little of modern cartoons.

The pictures, which were relatively inexpensive and thus widespread, were scrutinised with some suspicion by censors. Their subversive potential was able to unfold above all, however, when they relied on the language of Aesop. Animals, mythical creatures and figures were depicted to avoid suspicion of reference to current issues. It is important to realise that caricaturists had this lubki tradition to draw on when they established, developed, professionalised, and spread what became the Russian caricature tradition, in the context of Napoleon's rise. By the $19^{\text {th }}$ century lubki were produced as lithographs, but the original aesthetics were retained and served Russian avant-garde art in the early $20^{\text {th }}$ century as an important aesthetic source.

Let us take a brief look at the current state of research: researchers have only very recently started to focus their efforts on the tradition of lubki and anekdoty, in particular in Anglo-American academia, and in Russia itself, although it should be said there was some relevant material collected in the 
late $19^{\text {th }}$ century (A.D. Rovinskij) and used in the 1912 centenary. Particular credit is due the American art historian John E. Bowlt, who already complained in the 1970s that the caricatures of the pre-revolutionary period were far too little researched (cf. Bowlt 1983). He pointed to the importance of the cartoons of the Napoleonic period, in which the caricature first emerged as an independent phenomenon, particularly through the conscious activation of the Russian lubok's stylised design.

Bowlt's rather generally worded thesis was followed up and sharpened by a number of Western and Russian researchers and supported by an abundance of material. Particularly noteworthy is the scientific work of Stephen M. Norris, who directs his gaze from the Patriotic War up to well into the $20^{\text {th }}$ century with his 2006 monograph A War of Images. Russian Popular Prints, Wartime Culture, and National Identity, 1812-1945 (cf. Norris 2006). Work published later on either focuses on individual epochs (such as Nedd 2009 or Milne 2006) or examines caricatures mainly in the context of discourses on national identity. With the latter in mind, Višlenkova's paper published in 2005 with the programmatic title Vizual'nyj jazyk opisanija srusskosti< is particularly important (cf. Višlenkova 2005). She examines not only the discourses on constructing the »Russian«, but in particular the popularisation strategies and communicative processes at work. The recently published article by Čerepanova that appeared in a remarkable but limited print run of the RGGU conference proceedings (cf. Čerepanova 2011) is particularly noteworthy insofar as the focus is on the figure of Napoleon himself.

What we don't have so far are general surveys or works dealing with the phenomenon of the comic, of jokes, and the use of text and pictures. I will attempt to do this in my paper, or at least outline an approach. To do so, I will deal with three aspects in the context of laughter, humour, wit, and satire as they relate to Napoleon and Russia. The first aspect is functionalisation; the second is impact or effect; and the third is aesthetic strategies.

\section{FUNCTIONALISATION}

Research has convincingly shown that caricatures of Napoleon particularly during the Napoleonic wars were part of state propaganda and were thus encouraged in the interests of the State. A form of satirical, political war journalism arose, which took on an increasingly patriotic tone after 1812 . 
The intention was to activate the population's fighting spirit, to demonstrate the superiority of the Russian Empire, and to reduce the threat of the foreign troops. Ridicule and mockery of the foe are old strategies for demoralising enemies and strengthening the morale of - in this case - the Russian forces. The medium used was above all the lubki, by then already established and now developed further by professional artists working in the genre of caricature. Altogether 200 lubki appeared during the Napoleonic Wars, 72 of them featuring the figure of Napoleon. There is evidence that over 40 artists were employed in this war of pictures against Napoleon.

However, ridiculing, mocking, and humiliating the enemy, given the historical background and certain cultural conditions in Russia, was very much an ambivalent venture: The French, after all, were not considered by Russian society in general as the enemy. Au contraire! France had been the Leitkultur for Russia since the $18^{\text {th }}$ century: the aristocracy spoke French, fashion was copied from France, Russian salon culture modelled itself on the French equivalent. This orientation was not altered by the French Revolution.

Furthermore, the new type of ambitious, active, strong-willed self-mademan embodied by Napoleon did indeed fascinate the Russians, from the Czar to the reform-minded nobles, but at the same time he was a figure of hate to them. Thus the reactionary Czar Paul regarded Napoleon as a shining figure who had conquered chaos and fostered law and order. At the same time the Russian aristocracy regarded the young Alexander, who like Napoleon came to power through a coup d'état, as a type of »Russian Napoleon«. So to begin with, they were not unimpressed by the heroic dimensions of Napoleon's rise, his deeds, his reforms, and his willpower. However, the direct comparison with Napoleon showed up Alexander's weaknesses: his reforms were hesitant, half-hearted and did not really measure up to those of his model, Napoleon.

The ultimate in ambivalence in Russia's attitude towards Napoleon came after 1805. On one side there was the anathema of the Orthodox Church on Napoleon, who was branded the Antichrist, the Black Czar, the incarnation of the Devil. On the other side of the scales there was the Treaty of Tilsit, signed in 1807 between France and Russia, and in fact an act of betrayal on the part of the Czar, who was thus bound through an anti-Christian contract with the enemy of mankind. This treaty put Alexander I in a very problematic position within Russia right up until 1812: public comment on the external loyalty of the Czar to his »new brother « Napoleon was not permitted. After the campaign against the Russians and the fire of Moscow it was clear to everyone, however: Napoleon was effectively in alliance with the Devil. 
Nevertheless, it was also possible to interpret the Treaty of Tilsit in the light of Russian Messianism, and this was in fact done in the following way: the Treaty could be seen as an act of Russian Orthodox clemency, one last chance to lead the enemy of Christendom back onto the path of truth and virtue. This discourse of »Russia as a redeemer« was to become particularly powerful in a different context in 1812 .

According to this narrative, Napoleon had not only wasted this opportunity by invading Russia, but had also (inadvertently) helped Russia to define its self-image and its role within Europe for the first time. Thus the struggle against Napoleon took on several layers of significance or symbolic meaning:

- As the struggle against the consequences of the French Revolution and thus in favour of the old autocracy,

- As a war of culture against gallomania,

- As the struggle for the grand concepts of the Enlightenment, which had developed in the wrong direction in France,

- As the struggle for Russia as a genuinely European land which was to save the continent from despotism, even from barbarism as represented by the French,

- As a struggle for peace in the world,

- As the struggle against pure Evil in an essentially metaphysical form. The sacrifice of Moscow can thus be interpreted as the start of the process of bringing down and overcoming the Antichrist.

This philosophy of struggle is reflected in several variations in the caricatures which deal with 1812 and Napoleon, but also in the pictures that show the victory as a miracle: Russia conquers the Antichrist and frees Europe, which had been seduced into believing in a Utopia and was now delivered by Russia, by its people, and by its supposedly weak-willed Czar Alexander (though this point was not part of the discourse until later).

It is important to note that Russian society's longing for a hero, a grand historical figure regained popularity after only a brief interval, and there was a reinterpretation of the figure of Napoleon. In opposition circles, above all, he was now considered a genius, the legitimate successor of the Revolution, and as the man who shook the thrones of the emperors and czars. As early as $1814 / 15$, particularly in literary discourses, Napoleon is once again an immortal name and a »great $m a n \ll$, but one who failed to reckon with Russian hearts and their readiness to sacrifice their lifeblood: Napoleon thus becomes the ultimate Romantic hero. 
Right up to today, Napoleon caricatures and jokes illustrate a marked oscillation between these two poles of a divided nature: human and satanic, grand but terrifying. There is covert admiration for the French genius, elevated to a unique figure who could be stopped by nothing and no-one. And then he is the incarnation of the hubris typical of a Western individual, hubris that becomes laughable weakness, shown up by the Russian people and Russia itself. One can detect certain subversive and suggestive features in the contemporary caricatures: The people rather than the Czar Alexander fought off the aggressor, a version which initially even met with official sanction.

It is possible to detect how caricatures of Napoleon have been functionalised right through the $20^{\text {th }}$ century and up to the present. The satirical depiction of Napoleon in the Crimean War as well as in both World Wars had the potential to mobilise the population whenever the ruling powers were under threat. The figure of Napoleon stood for the ultimate threat, for a desperate situation, but at the same time for the victory of spiritual and moral powers over material values. Above all it served as a warning to the enemy. An example of this is a caricature of the artist collective Kukryniksy from 1941, in which the text $\gg$ Napoleon suffered a defeat, and so it shall be with the swaggering Hitler too! « (cf. Fig. 2) draws a direct parallel between Napoleon and Hitler.

Figure 2: »Napoleon suffered a defeat, and so it shall be with the swaggering Hitler too! «

Plakat. Chromolit. 1941

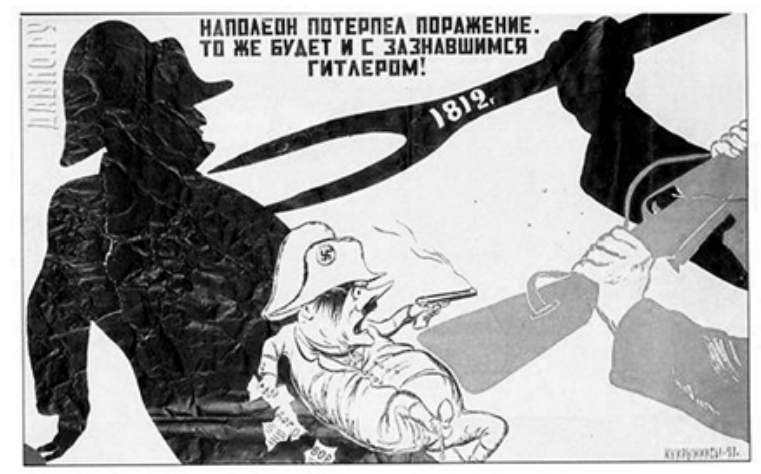

Source: Gosudarstvennyj russkij muzej (inv. Gr. pl. 469) <http://cs1851.vkontakte ru/u2008214/96409515/x_89cbc5 9d.jpg> 
However, if we look at today's Napoleon caricatures and jokes using the new medium of the Internet, then it is very obvious that the figure of Napoleon is now used as emblematic of questionable claims to power and dictatorship within the country itself. Whereas up to the Second World War the enemies of Russia were identified with Napoleon, ever since Perestroika, it is the country's political leaders themselves. The small stature of both Medvedev and Putin are brought into play here. It is possible to read the following points of criticism out of the subtext of the Napoleon figure: disproportionate ambition, unbridled desire for power, westernisation (regarded as dangerous for Russia), individualism and finally the message that downfall (awaited, or even longed for?) will come.

»What is the difference between Napoleon and Putin? Napoleon had the complex a small man has. With Putin it is the other way around.«

What makes the matter more complicated is the fact that Putin himself lays claim to the Napoleon myth for himself and his politics. This can be seen, for example, in his legendary election campaign appearance in Lužniki in February 2012. In this event, which received wide coverage via television and the Internet, the battle of Borodino was explicitly addressed in order to get the Russian people (of today!) to commit to the defensive struggle against the »enemy«. It remained unclear, however, which »enemy « currently threatened the existence of Russia as fundamentally as Napoleon 200 years ago.

\section{THE IMPACt OF THE NAPOLEON CARICATURES OF 1812/13}

The Napoleon caricatures were successful in many ways. The figure of Napoleon led to a rapid development of the genre of caricature itself, and what is more, under the patronage of the State. There was innovation in the choice of figures that were portrayed. For the first time in this pictorial form, Russian peasants were regarded as worthy of being depicted, and moreover in an extremely positive light: one could say as the embodiment of the Russian people; something that continues to play a significant role in the discourse over national identity. Furthermore, it should be underlined that Russian artists and their caricatures of the figure of Napoleon became known in Western Europe, where they found a number of enthusiasts (cf. Bowlt 1975: 59). And perhaps most importantly: the caricatures that were created during 
Napoleon's lifetime formed archetypes that were activated over and over again in later periods right up to the Second World War.

Above all, the mysterious, inexplicable, fateful downfall of the European army, symbolised in the figure of Napoleon, served as a warning. His downfall can be read emblematically and the subtext for the West is clear: It is dangerous to go into Russia. Whoever tries it will meet with defeat!

\section{The Aesthetics or Strategies of the Comical}

The underlying narrative of contemporary caricatures around 1812 was the contrast between the positively-connotated Russian national characteristics and the miserable state of the French Army, as embodied by Napoleon himself. Constant elements of the narrative are: love of Russia, the celebration of Moscow, the symbiosis of peasant and Cossack (moral and military power), the de-mystification of Napoleon.

In the caricatures as well as in the anecdotes Napoleon himself is frequently the centre of focus, in a highly standardised form: his small stature, three-cornered hat, typical placement of his arm. Napoleon is thus the primary >legitimate< subject of portrayal.

According to Graham (2003) the psychological effect is derived from a number of elements. First of all, the feeling of superiority that arises through laughing over the bad luck or misfortune of others. This sense of superiority is stronger when the person depicted is of a higher social status than the viewer. This was the case with the western European soldiers who had traditionally been regarded as culturally superior, and of course it was even more the case with Emperor Napoleon. Secondly, the preservation of mental and emotional stability when one sees that others survive dangers and overcome the enemy (cf. relief theories, especially in Freud!). The third aspect, described by Graham as Incongruity Theories, is the activating of laughter as the response to the occurrence of two pictures or ideas that cannot be logically brought together (frequently the case with the double semantics of one and the same sign). This can be found more often in anecdotes told today:

»A pupil comes home from school. The mother asks: What did you learn today? The son: where Napoleon died. Mother: And where did he die? Son: on Saint Helena. Mother: Tut, tut. What dirty stories you learn at school these days!« 
To return to the $19^{\text {th }}$ century: the strategy of discrediting the enemy can be described by means of the play between the noble and the ridiculous, whereby Napoleon's titanic genius and imperial status constitute the noble overlay that is torn down and made to appear ridiculous.

Thematically and iconographically the caricatures have a broad span: for example, in the contrast between the individual and the collective. The »Übermensch«, Emperor Napoleon and his individual willpower are defeated by the collective will of the Russian people, symbolised by the Cossacks as almost mystical heroes, and then complemented by the peasants and ordinary soldiers. Many of the cartoons created directly during the war years reveal peasant figures. For example, the representation in Figure 3 shows Russian peasants who make the French soldiers (or even Napoleon himself) literally »dance to their tune«. Figure 4 presents a Russian peasant woman threatening the French soldiers with a goat.

One particular form of inversion occurs when artists resort to classical aesthetics, which are then re-coded as authentically Russian, for example with the Russian Hercules figure, who towers over doll-sized French soldiers (cf. Fig. 5).

Figure 3: Ivan Terebenev: Napoleon's Dance (1813)

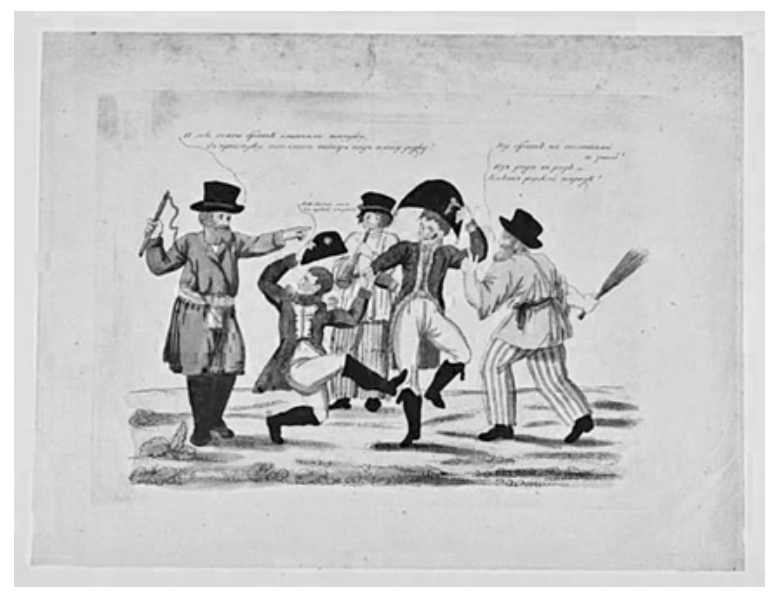

Source: 〈htpp://1812 nsad.ru/pic/narodnye_pesni_1812_karikatura_org-jpg> 
Figure 4: Ivan Terebenev: French marauders get frightened by a goat (1813)

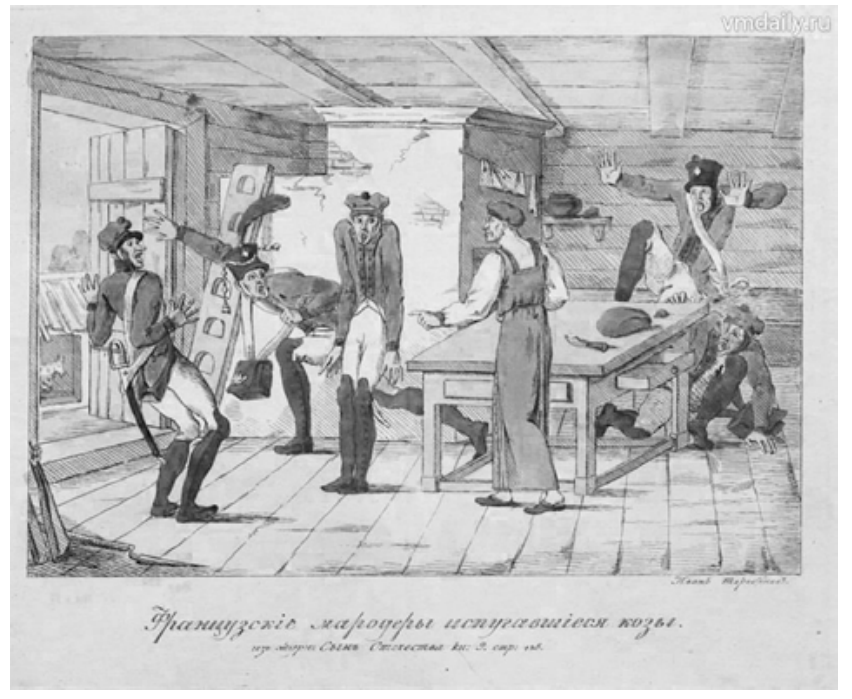

Source: <http://www.vm ru/photo/vecherka/2012/08/file66e6nkojvh u5zqlkdv5_800_480.jpg>

Figure 5: Ivan Trebenev: The Russian Hercules of the town of Syčevka (1813)

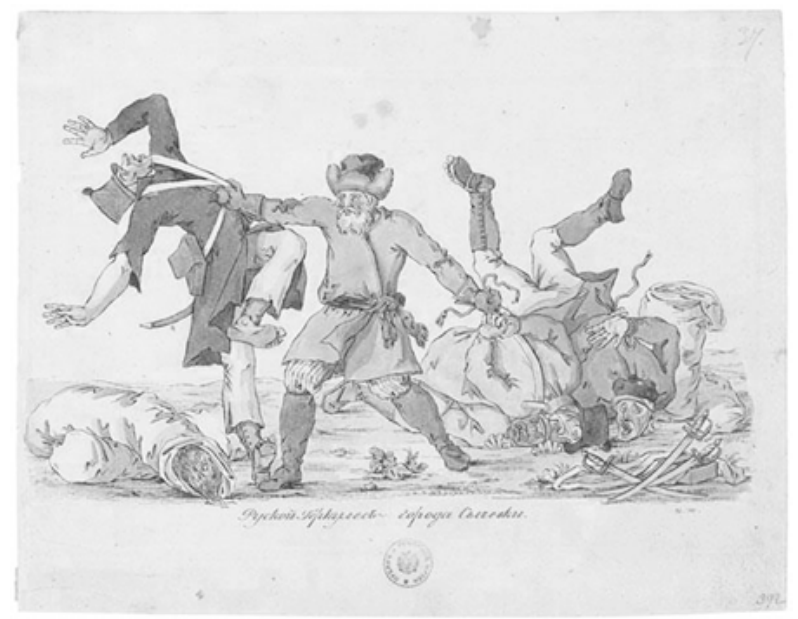

Source: 〈http://www russianprints ru/files/2207_600.jpg> 
The Czar himself, in a sense the »natural « counterpart to Napoleon, is not in these caricatures, no doubt as a result of his own (unsuccessful?) politics. Closely aligned to this is the contrast between courage and cowardice. The latter refers above all, of course, to the Grande Armée, usually depicted in a deplorable state.

Another aesthetic strategy is to discredit the Napoleonic army by »dehumanizing « it. A particularly drastic example is shown in the cartoon in Figure 6, in which Napoleon is subjected to a special treatment with a laxative and is actually presented with trousers full of excrement.

Figure 6: Ivan Terebenev: The Retreat or The effect of Russian laxatives (1813) »Cossack: Get quickly on the road back home, and tell all your lot you've managed to bring everything to your forces that you' ve got from the Russians as pillage. Peasant:And what you can't carry away in your ***, put in your hat."

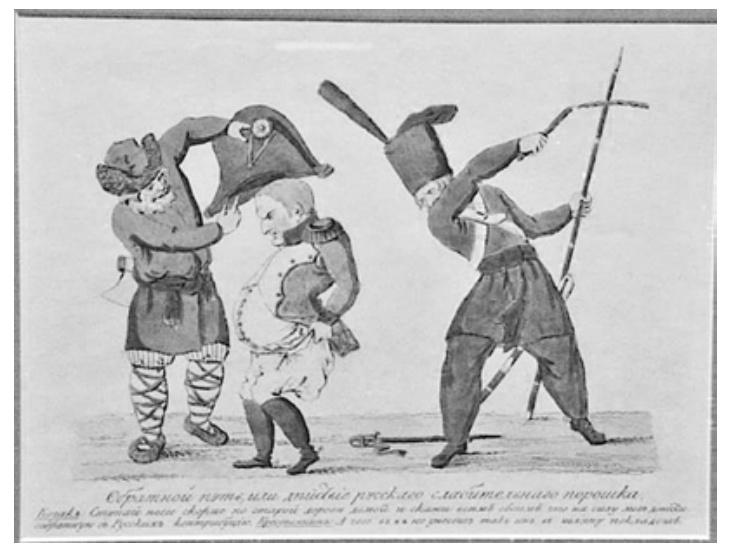

Source: <http://www russianprints.ru/files/2201_350.jpg>

There are also examples where this strategy of »dehumanization« is achieved by placing the French soldiers not only metaphorically but also visually on the level of animals. The cartoon in Figure 7 shows Napoleon and his soldiers as anxious rabbits on the run, fleeing in panic from the incarnation of the Russian winter and Russian cold in the form of the Russian peasant Vavila Moroz (= frost). 
Figure 7: Unknown Artist: The Russian peasant Vavila Moroz on a rabbit hunt

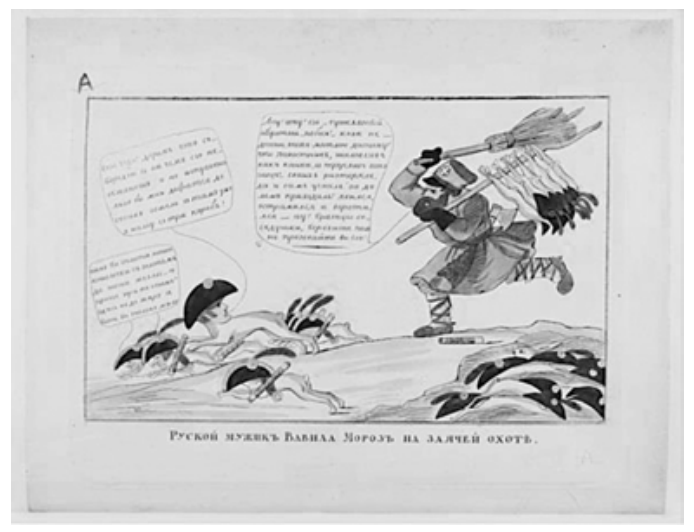

Source: <http://4.bp.blogspot.com/-6gMX- spsGfY/T xwIfCsU19I/AAAAAAAABTw/AFb5mRK7F54/s640 /canvas.png>

Also interesting in the context of discrediting the enemy is the play on gender stereotypes. The most important strategy used is the emasculation of French troops, who are not only at the mercy of the Cossacks, soldiers, and peasants, but also of the womenfolk. Figure 4 gives the impression that the soldiers of the Grande Armée were even afraid of female animals such as nanny goats, with whose help a Russian peasant woman chases off a whole company of soldiers.

Additionally the close intertwining of discourses about Napoleon and homosexuality shows just how virulent playing with gender stereotypes and sexual innuendo was.

Closely related to the contrast between the noble and the ridiculous is a procedure which I would like to call inversion. By this I mean a procedure followed in caricatures and anecdotes whereby cultural stereotypes, positive and negative prejudices, awareness of the self and the other are addressed and transformed.

One example of a contemporary anecdote:

»Napoleon waited in vain for the keys to the old Kreml. The keys were probably stolen at some point, or maybe they were just lost.« 
Here we have an allusion to the negative cultural attribute (Russians steal, or are careless), re-coded into a strength in an affirmative and at the same time subversive process.

There are many such cases of inversion where the French culture is discredited as a superior culture through being presented as completely degenerate. Napoleon and his soldiers thus stand for sthe Other of the Russian culture, and are given ironic treatment. The >liberation` or >cleansing \& of Russian soil from degenerate western culture was visually captured in a caricature entitled »French actresses exiled from Moscow« (cf. Fig. 8)

Figure 8: Aleksej Venecianov: French Actresses Exiled from Moscow (1812)

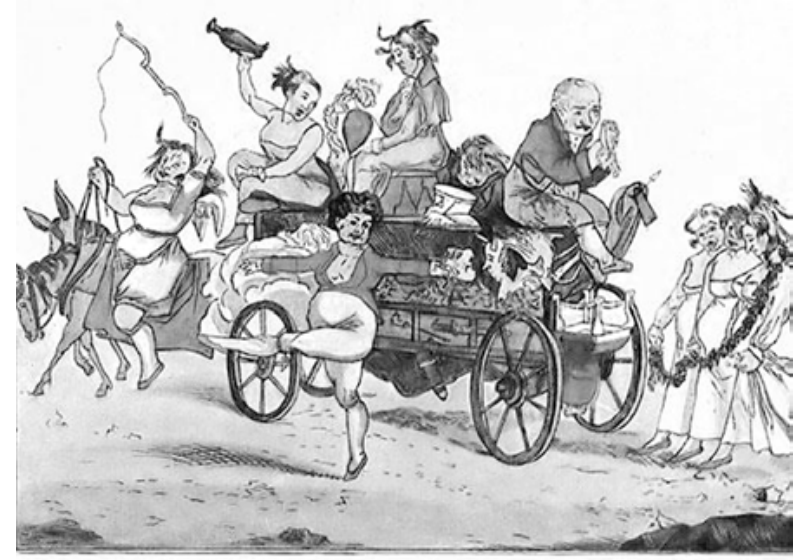

Изгианіе изъ Москв: французскихъ актрисъ.

Source: <http://antikvar.ucoz.ru/_ld/1/92048.jpg>

In similar vein is the ironic representation of the world-famous French cuisine, which is reduced to not much more than crows soup (cf. Fig. 9). 
Figure 9: Ivan Terebenev: French crow soup (1812)

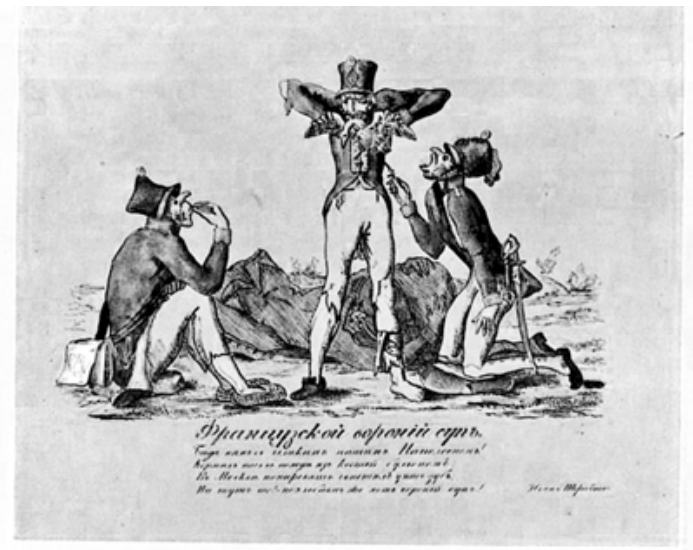

Source: <http://museum nsk ru/museum/images/rovinsky300-1.JPG>

Another example is the treatment of France as a superior culture which literally has to dance to Russia's tune or fife (cf. Fig. 3).

Cultural stereotypes about Russia undergo a similar inversion process, for example Russia's proverbial hospitality, or the famous Banja, but also the intense cold that is always associated with Russia. This technique of inversion is evident right up to the present, for example when the significance of Napoleon for Russia and France is the subject of an anecdote and the already familiar double meaning of the word Napoleon is activated.

\section{SUMMARY}

I would like to conclude with a brief summary of the subject Napoleon, humour and Russia:

First and foremost, it is clear that the Napoleon myth, as present in the humorous and satirical discourses of the czarist and the Soviet period, was above all functionalised in accordance with the intentions of the State and in the context of war. The aim was to activate the country's defences and to discredit the enemy. It is only in very recent times, that is, in the last twenty years, that in urban folklore (i.e. in anecdotes and online) Napoleon is being functionalised as a figure in counter-discourse and in confrontation with the State. 
Even today both discourses still stand next to each other and are connected above all by humour and irony. The one, supportive of the state, stages $\mathrm{Na}-$ poleon on the one hand as Russia's enemy par excellence, and on the other hand as a test for Russia, which can secure its national identity only in the face of this hostile threat and by successfully overcoming it. The other discourse, the one that moves in internet forums and urban folklore, in anecdotes and jokes, in media spaces that are difficult for the state to control, uses the figure of Napoleon to refer to dictatorial phenomena at home. But what all discourses have in common is that they play with western figures and clichés.

\section{LITERATURE}

Bowlt, John E. (1975): »Art and Violence: The Russian Caricature in the Early Nineteenth and Early Twentieth Centuries «. In: Twentieth Century Studies, Canterbury, 13/14, 56-76.

Bowlt, John E. (1983): »Nineteenth Century Russian Caricature«. In: Theophanēs G. Stauru (ed.): Art and Culture in Nineteenth-Century Russia, Bloomington: Indiana Univ. Pr., 221-236.

Čerepanova, R. S. (2011): »Napoleon Bonapart kak figura russkogo nacional'nogo samosoznanija«. In: N.M. Velikaja/E.D. Gal'cova (eds.): Napoleonovskie vojny na mental'nych kartach Evropy. Istoričeskoe soznanie $i$ literaturnye mify, Moskva: Kjuč-S, 176-193.

Graham, Seth Benedict (2003): A Cultural Analysis of the Russo-Soviet Anekdot, Pittsburg.

Milne, Lesley (2006): »»Novyi Satirikon〈 1914-1918: The Patriotic Laughter of the Russian Liberal Intelligentsia during the First World War and the Revolution«. In: The Slavonic and East European Review 84/4, 639-665.

Nedd, Andrew M. (2009): »Segodniashnii Lubok: Art, War, and National Identity«. In: Pearl James (ed.): Picture This. World War I Posters and Visual Culture, University of Nebraska: Lincoln \& London, 241-269.

Norris, Stephen M. (2006): A War of Images. Russian Popular Prints, Wartime Culture, and National Identity, 1812-1945, DeKalb, Ill.: Northern Illinois Univ. Pr.

Višlenkova, E. (2005): »Vizual'nyj jazyk opisanija >russkosti< v XVIII - pervoj četverti XIX veka«. In: Ab Imperio 3, 97-14. 



\title{
Alfred and Friedrich Alfred Krupp as the Butt of Jokes?
}

\author{
The German Perception of the Economic Elite in the \\ $19^{\text {th }}$ Century
}

AXEL HEIMSOTH

\section{The BeginNING}

In the beginning there was admiration. The newspapers reported in a detailed way on the Krupp products. Along with the increasing interest of the press, the company from Essen also found its way into caricature. It was the cartoonist Wilhelm Scholz (1824-1893) who first humorously approached the Krupp cannon in the German journal Kladderadatsch in 1867. The occasion for that was the World Exhibition in Paris where the steel company presented the biggest piece of artillery ever produced out of cast steel ${ }^{2}$ (cf. Krupp 2011). That gun, which weighed 47 tons, caused a great sensation in the metropolis. This was used by Scholz to convey the superiority of the German weapons to the German readers. However, in 1867 there still was uncertainty, especially among the public in Paris, concerning the functionality of the cannon. One French visitor reported that people wouldn't think too much of such a weapon and that they would probably regard it as attraction rather than as a danger. That fatal misjudgement should become clear in the German-French war of 1870/71, because the reviewers were put right afterwards. The Krupp weapons had a significant share in Germany's victory over France.

1 I would like to thank Johanna Koczor und Dr. Stefan Siemer in Essen for the English translation of this article. 
Figure 1: »On the occasion of the presentation of the Krupp cannon, the Kaiser [Napoleon III] is said to have been completely carried away at times."

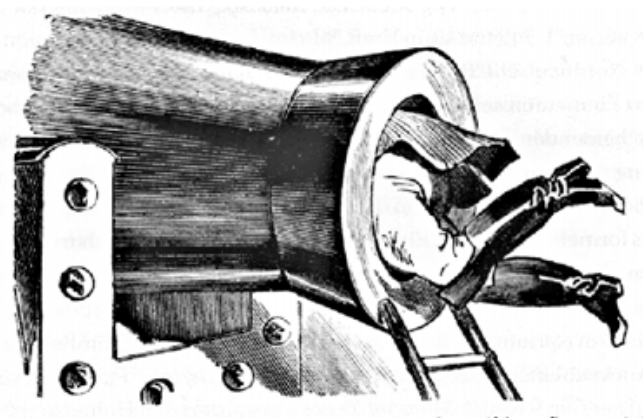

Pei ter cingebenten Bejidtiguag ter srupb'imen sanone foll Der Stailer fitellemseife gan wea gervejen fein.

Source: Journal Kladderadatsch Nr. 27, 16.6.1867

lithographic print, Dr. Stefan Siemer, Essen

In 1867 the signs certainly didn't point to a war between Germany and France, but there were some tensions, which heated up the atmosphere on the political level. This is why the fact that the magazine Kladderadatsch caricatured the Fried. Krupp Company depends less on the company itself than on the tense situation between the two nations. Scholz was also the one who established his reputation in Kladderadatsch in the course of the next years in illustrating the two big figures: the emperor Napoleon III of France and the Chancellor of the German Reich Otto von Bismarck. This is why Scholz's cartoon of 1867 should be judged as a political caricature: the political elite in France was satirised because of their inability to realise the progress of the weapon's technique and to undertake suitable measures in order to build up an efficient arms industry. The message is: The French emperor, Napoleon III would have >lost himself in the German gun. Only the German side would have been able to produce such technically outstanding and sophisticated weapons. 
Figure 2: Krupp cannon - World Exhibition in Paris stereoskopy, foto 1867

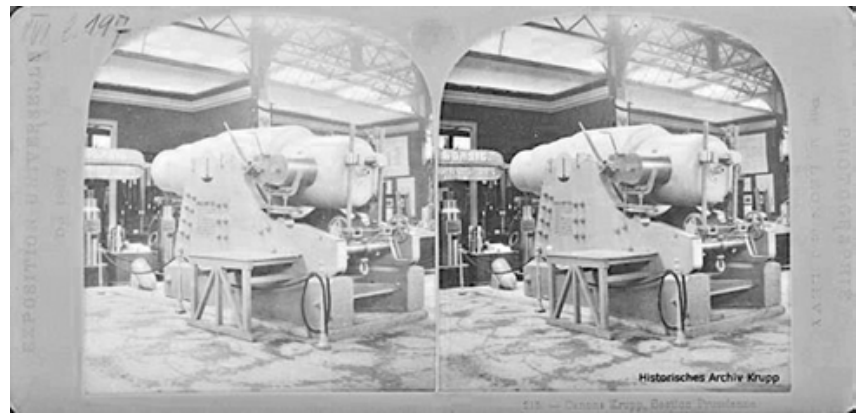

Source: Historisches Archiv Krupp, Essen

\section{The ReAsons}

In the 1860s, the Fried. Krupp Company enjoyed recognition in the national as well as in the international press, because it caused a sensation with its new steel products - especially with the steel cannons (cf. Gall 2000; Gall (ed.) 2002; Beyer 2007; Grütter (ed.) 2012). That was the new and unusual thing about the Krupp products that determined the public perception. This »unique selling point « of technical advanced weapons was, in connection with the rising level of awareness, the reason why satirical magazines gave the company so much attention. Because only when the magazine readers were aware of the company Fried. Krupp from Essen, could the caricature react to a new theme relating to the upcoming steel company. It is important to the cartoonists to combine recent political events (scandals, grievances or the >big happenings $<$ ) with the famous persons, enterprises and geographical places. The moment of the news must be related to the everyday event in order not to overtax the audience. This is how Krupp found his entry into the caricature canon in the $1860 \mathrm{~s}$.

What kind of company was it which emerged amid such publicity under the aegis of Krupp? In 1811 Friedrich Krupp established his company in Essen. At the beginning he had some partners. Later he managed to singlehandedly invent the high-class cast steel anew. This discovery, that one could re-melt the >normal steel and thus obtain top-quality cast steel, had already been made by the English in the middle of the $18^{\text {th }}$ century. They exported the premium quality but expensive semi-finished and finished 
products (e.g. knives) to the European continent, but only until Napoleon's Continental Economic Blockade started. The French prohibition in 1806 of importing goods from England was the moment that many German producers making use of new production processes established successful new industries. Without the English competition between 1806 and 1813 they could fill the market niche on the continent. In Essen Friedrich Krupp found such a gap in the market for products made out of cast steel (cf. KöhneLindenlaub 1982; Heimsoth 2012a). His factory produced special tools, coiner's dies and semi-finished products (steel bars); however the initial difficulties were enormous. At his death in 1826 he bequeathed to his wife a company with only seven employees left and 10,000 thalers of debt (cf. Gall 2000: 40-45). In any case, Friedrich had gained control of the complicated production process of cast steel, which was an achievement that his wife could build on. Upon his father's death, 14-year-old Alfred joined the company and helped his mother to run it. This was the case for the coming years. The little enterprise to the west of Essen city centre produced special steel products for individual branches. The majority of the cast steel was still produced in England, the land that busily exported its products again after the Continental Economic Blockade was lifted (1813). Still, Krupp could hold steady in some business areas despite the English competition. The mints and the gold smiths (the Parisian Producer of Jewellery) obtained their special tools and machines in Essen. In the 1830s and 1840s the Krupp company gained much experience in fabrication of bigger workpieces of steel which they processed into rollers.

A new stage in the development of the enterprise started at the end of the 1840s. Responsible for this expansion was the owner of the company, Alfred Krupp, who carried out a new product and marketing strategy, led his firm out of the medium-sized special steel and machine production sector and entered the sector of ordinary steel fabrication. With the production of the railway material and cannons the sales figures exploded. To the railway companies Krupp sold rails, springs, wheels and sleepers. Alfred's invention of the seamless rail wheels in 1852/53 made him rich and famous (cf. Wuttke 2012; Heimsoth 2013). Sales of railway wheels were so successful that in 1875 Alfred Krupp chose three crossing rail wheels as his company logo, the Three-Rings-Symbol.

The production of the cast steel cannons developed into the second main pillar of the enterprise. In contrast to the railway material, the circle of customers buying armaments was rather limited. Only a few governmental units, including the chiefs of the state, were responsible for the purchase 
decisions. But how could the company reach diverse clientele with its catalogue of goods? How could an unknown firm from Essen in the 1850s get absorbed into the circle of internationally competing steel producers and weapon manufacturers?

The company's expansion in the 1850s was based on a new advertising strategy. Alfred Krupp was a marketing genius who understood the worth and the potential of the new medium of photography. He was the first to establish a company photographic department and to have Krupp products and display-stands photographed for promotional reasons. Alfred Krupp participated in the great world and industry exhibitions because he appreciated the importance of publicity for his company. Internationally, the firm had its big breakthrough thanks to its participation in the first World Exhibition in 1851 .

Figure 3: Krupp cannon, World Exhibition in London, 1851 lithographic print

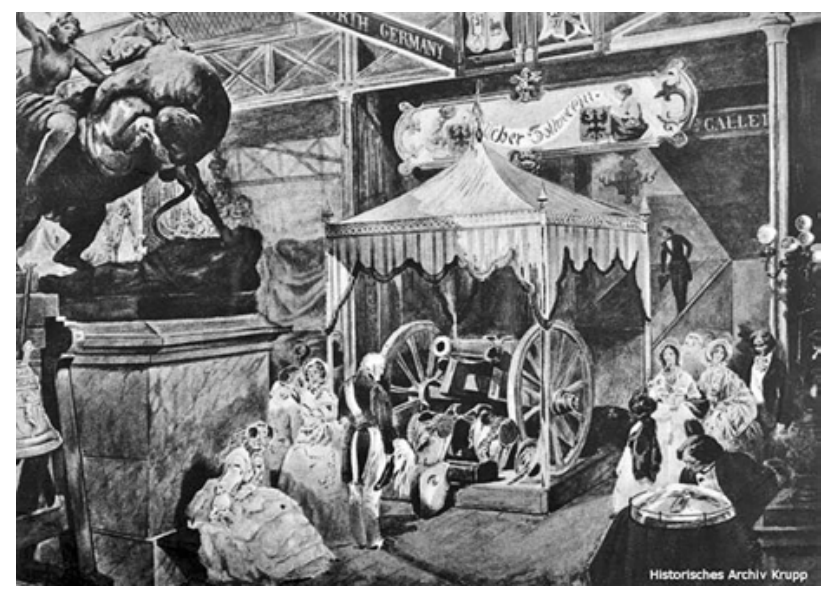

Source: Historisches Archiv Krupp, Essen

Corporations from around the world presented their products in London to the public and business clients. The companies let a jury evaluate their goods with respect to public opinion. Alfred Krupp could win one of the most desired great medals of merit. He was awarded the Council Medal for the biggest block of cast steel ever exhibited. That block of cast steel, as stated afterwards by the Generalanzeiger für Crefeld und Umgebung »[...] evoke[d] the world's amazement because nobody had seen anything like it 
before « (cf. Wolbring 2000: 94; Heimsoth 2012b: 235). In London, the company also caused a great sensation with the first ever cast steel cannon presented in public. With his bigger and bigger blocks of cast steel and greater and greater guns, Krupp was able to fascinate the public and the press over and over again during the next world exhibitions. The tremendous Krupp cannon exhibited during the World Exhibition in Paris in 1867 belonged to the company's tradition: to show the biggest possible gun und the heaviest possible block of cast steel.

\section{THE KING OF THE GUNS}

The sales of cast steel guns in the 1850s were developing slowly. Krupp promoted his weapons during the exhibitions and tried to convince the military administrations and commissions of the quality of his products. The firm invested much time and effort to make contact with the reigning princes and potentates worldwide in order to obtain armaments orders. Especially intensive relations were maintained by the company from Essen with the Prussian ruling house. In 1861 the Prussian king Wilhelm I visited the factory as the first Hohenzoller. His grandson, the emperor Wilhelm II intensified the contact to the Krupp company during his reign (1888-1918). In order to become familiarised with the present state of weapons technology, the German emperor visited the company in Essen ten times altogether and was also guest in Villa Hügel, the industrialist's family residence (cf. Kerner 2012: 210). The Krupp armaments concern was privileged by the state and provided critics with a target: now they could criticise the armaments orders of Friedrich Alfred Krupp as an illegitimate monopoly, although the orders had already been initiated under his father Alfred for the purposes of a »special relationship« (Epkenhans 2010: 82).

Alfred Krupp sold his cannons worldwide. Thanks to the big armaments orders in the 1860s, Krupp earned the title »The King of the Guns«. This favourable term can be found in the popular German entertainment magazine Die Gartenlaube, which in 1866 published the article »The King of the Guns «. That periodical praised the big armaments orders of the concern and the efficiency of its production facilities. The newspaper appreciated the military importance of Krupp cannons, but at that time it assumed that another weapon was more crucial for the Prussian victory in the Wars of German Unification. It was the needle rifle developed by Dreyse that was supposed to enable Prussia's victory in 1866. Throughout 1866, as emphasised 
by the newspaper, the technically well-engineered rifle was decisive for the war's outcome. However, the importance of military technology shifted only a few years later to the artillery. During the Franco-German War (1870/71) it was the fire power of the Krupp guns that turned the balance of the battle of Sedan (1870). The artillery knocked out the French troops and forced them to surrender. The French emperor, Napoleon III was then imprisoned at Sedan. The success of his cannons consolidated Krupp's reputation as the King of the Guns. The international press praised the vigorous effect of the guns as well. After the battle of Sedan, the Dublin Review wrote in October 1870:

»Since the days of Tubal Cain, no State has had the services of such iron-masters as Herr Dreyse and Herr Krupp. But the great men who swayed the empires, whose very centre and sanctuary were to be the billet of their bullets, held them in light regard. [...] it was at a mere threat from the infernal lips of Herr Krupp's cannon that the French Empire succumbed at Sedan.«(The Fall of the French Empire 1870: 486)

In France in 1871, one cartoonist reacted to Alfred Krupp's importance for the international arms trade: The entrepreneur is the actual ruler, a king to whom the other kings and princes have to pay homage. For a throne the illustrator depicted the Krupp cannon from 1867. Maybe he even saw the gun in person during his visit to the exhibition in Paris. The French artist saw the approach of a new age. The technocrats in the form of the weapon producers would mount the throne, which would turn the centuries-old power structure upside down: The kings and the emperors would have to worship Alfred Krupp if they still wanted to obtain their weapons from him. Because only those who joined in the sadoration< of the armament manufacturers according to the illustrator - could be sure to obtain the most modern arms technology in the future and to maintain the throne by those means. While the »King of the Guns Krupp« became more powerful than ever after the victory over France in 1870/71, the emperor Napoleon III was >flushed away. The capitulation of his army and his own capture by the Germans were responsible for his defeat at Sedan, where the Krupp cannons were so destructive. As an insignia of Alfred Krupp's authority, the illustrator gave him not a sceptre or crown, but a grenade. At the moment of defeat in 1871, the pessimistic approach of the French press regarding the armament industry was pointed towards Germany. Critique of the arms system and of the social problems caused by the high armament budget was made a subject of 
discussion a few years afterwards in Germany as well. The general public reacted with increasing criticism of the rising military budget.

Figure 4: »Krupp et son Las Nor Prévu/La

Force Primie/Le Droit« lithographic print, 1871, print: Caillot, Paris

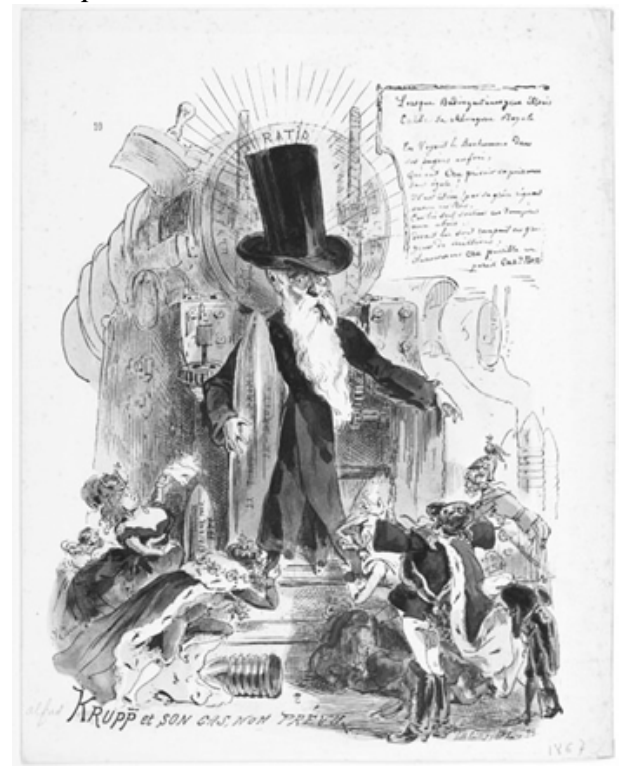

Source : Musée national du château de Compiègne

\section{The Capitalist}

Krupp provided all the countries with steel. The arms deals became increasingly complex and proceeded under the aegis of Friedrich Alfred Krupp (1887-1902). Friedrich Alfred, as the only son of the company's patriarch Alfred, took over the firm's management in 1887 and successfully continued to expand his enterprise. The concern from Essen absorbed the Gruson's plant in Magdeburg in 1893 and in 1896 acquired the Germania shipyard in Kiel. From now on Krupp could compete for naval contracts. The company both produced warships itself and delivered armour plates for the construction of further battleships. Decisions about the acquisition of the shipyard and about getting started in the construction of battleships were made by the company at the moment when Wilhelm II announced building up of his High 
Seas Fleet in 1896. The emperor complimented Friedrich Alfred Krupp by telegraph on the acquisition of the shipyard in Kiel (cf. Stremmel 2010: 42).

Friedrich Alfred Krupp was the sole owner of the whole concern, which was unusual. Namely, in the meantime the other big German enterprises had been transformed into joint-stock corporations. Krupp was different. Alfred braced himself vehemently against such a restructuring, arguing that he did not want to be dependent on the financiers (bankers). Friedrich Alfred Krupp followed the example of his father and held on to the sole ownership of his company, which had its advantages and disadvantages. The slim company structure was convenient when it was important to make a decision. Also favourable was that due to such a legal form, any financial transactions could be disguised. A joint-stock company must be much more transparent than a private enterprise because it needs to report its benefits and the state of its property to the shareholders. Friedrich Alfred experienced the disadvantages of sole ownership much more harshly than his father: He became a target of caricature. The cartoonist identified the owner with his firm in order to discredit it. For example: There was a rumour that Krupp wanted to set up a weapons factory in Russia and the magazine Ulk used this rumour to illustrate Friedrich Alfred Krupp with a crown and waist scarf. On the scarf was written the company's name: »Fried. Krupp«. While Krupp pointed with his right hand towards the Russians, indicating the extraordinary quality of his weapons, his left hand held a bag of money - that should reveal him as a capitalist. 
Figure 5: »Deutschland, Deutschland über alles!'«»Die Firma plant dieErrichtung einer Fabrik in Rußland zurHerstellung von Geschützen für die russische Regierung (Zeitungsnachricht).«(»The company plans to build a factory which will provide the Russian government with cannons (notice in a newspaper).«)

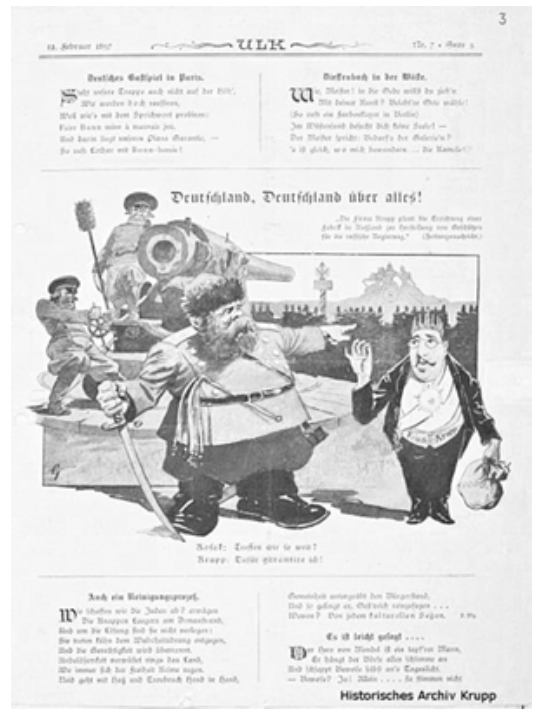

Source: Journal »Ulk« Nr. 7, 12.2.1897, lithographic print, Historisches Archiv Krupp, Essen

The export of weapons, however, was reported by the press more and more critically. One reprove questioned whether also the potentially hostile nations as France could and would obtain Krupp arms (cf. Wolbring 2000: 222-225). On the other hand one pressing question was: If the quantity of the exported cannons was so high, than wouldn't all warring parties finally be equipped with the same arms system? More and more nations bought Krupp guns and it was only a matter of time until two countries with the same weapon systems would wage war against each other. The attacks in the newspapers against the firm resulted from loss of confidence on the part of the general public. The satirical magazines represented the voice of those who inquired into the sense of the arms race. Alfred Krupp was not criticised till the 1880s, when he enjoyed the position of the »King of the Guns « and maintained his tight relations to the court and especially to the German Kai- 
ser. That changed, however, in the 1890s under his son Friedrich Alfred Krupp. He had to fight in public against loss of credibility regarding both his company and his person. The reason was that the memories of the war of 1870/71 had faded away. The Krupp cannons lost their actual function because they were no longer applied. Germany conducted no wars until 1914, apart from minor military actions including the Boxer Rebellion in China (1900) and the Herero und Namaqua Genocide (1904-1908). The weapons served as a simple threatening gesture and were only numerical data for the politicians and military. The more weapons the others had, the more one had to invest in one's own military preparation. Based on this logic, the arms race was >virtualk. A threatening scenario of threat was articulated, the armaments budget was applied for; the weapons were bought and deposited in the barracks. The armaments costs were immense and the population had to bear the costs. Such a system was profitable only for the armaments manufacturers. The public opinion stated that the bigger guns one constructed, the thicker the armour plates the industry would build for the battleships. Only a small group of arms producers like Friedrich Alfred Krupp in Essen and Carl Ferdinand Stumm in the Saarland would get richer and richer this way. The consequences of the arms race were illustrated for example in the cartoon dated 16 March 1900 (cf. Zolper 2012: 37). 
Figure 6:

»Die Marine-Brüder «

»Stumm: Je schwerer du deine Geschütze machst, / Krupp: Je

schwerer deine Platten, / Beide: Desto schwerer werden wir selber.« (»Stumm: The bigger you make your cannons, / Krupp: The bigger your boards, / Both: The bigger we get ourselves. «)

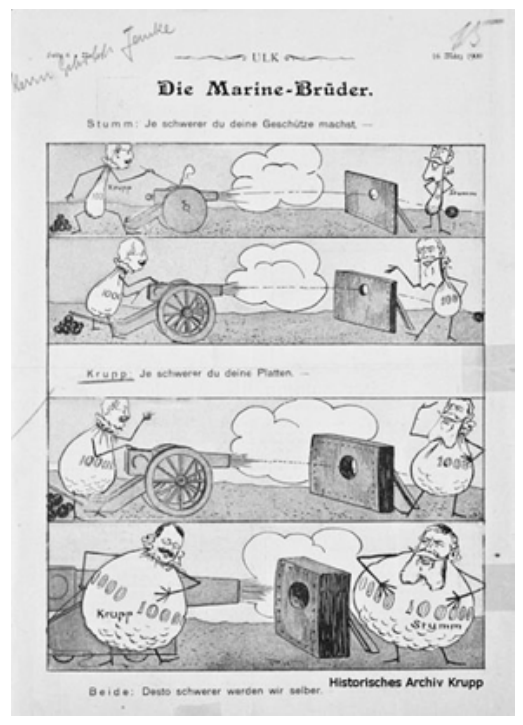

Source: Journal »Ulk«, 16.3.1900, lithographic print Historisches Archiv Krupp, Essen

The occasion for the caricature »Die Marine-Brüder« in the satirical magazine was the rivalry in the construction of the Battle Fleet. During the Reichstag's budget commission sessions, the social democrat August Bebel and the liberal Eugen Richter attacked the armaments industry. They accused the steel producers Krupp and Stumm of maintaining a monopoly in the production of steel plates for the construction of warships (cf. Wolbring 2000: 283-284). One of the critical arguments was that they would offer the weapons at excessive prices - something definitely denied by the Fried. Krupp company. A few days after the publication of the caricature against Krupp and Stumm by the satirical magazine, the Kölner Volkszeitung on 22 March 1900 demanded a guarantee that »the ships and cannons did really have the real worth that should be paid for them otherwise maybe a few industrialists would earn enormous sums with their monopoly « (quoted after Wolbring 2000: 87). That difficult situation became worse and worse in the 
coming years. The question as to who profited from the armaments, who gained from them, remained virulent.

\section{The Demon}

Controversies about Krupp's armament production were eagerly attacked by the press. Moreover in the field of foreign affairs it became more and more evident how much the lobby of weapon dealers was based on international relations and policy. Things went wrong especially for Krupp as a producer of armaments during the Boxer Rebellion, when the firm got a disastrous bad press. In 1900 Chinese rebels besieged the diplomatic quarter in Bejing and fought back an army that had been set up in advance by the Europeans. Their success was based on some of Krupp's canons which they had got from the arsenal of the Chinese army. This was eagerly covered by the press, who was maintained that weapons had been delivered to the enemy by Krupp, which was in fact true. In the past Krupp had delivered some weapons to the Chinese army (cf. HA Krupp, D 22, Beziehungen, Ländereien und Städte). Some of them then were used by the Chinese rebels. The press picked up one message: The European army has been attacked by the Chinese using Krupp weapons. The satirical magazine $U l k$ reported on 13 July 1900 a stalemate: both parties possessed weapons made by Krupp. In the background Friedrich Alfred Krupp figured as »demon Krupp«, sat on his throne. It was the owner of the firm who profited from the war. 
Figure 7: »Dämon Krupp«

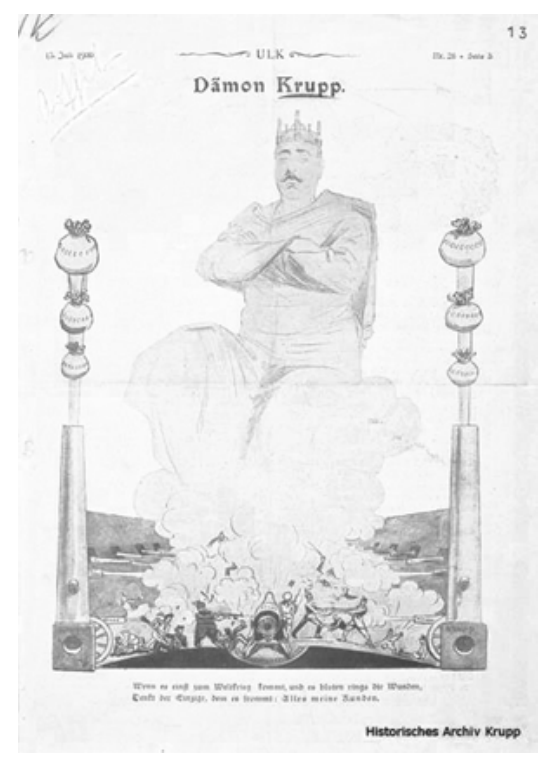

Source: Journal »Ulk« Nr. 28, 15.7.1900, lithographic print Historisches Archiv Krupp, Essen

Meanwhile caricaturists questioned Krupp's patriotism - he was the »demon Krupp « who, while pretending to be a patriot, forced up his prices for weapons in order to get richer - he was confronted with new accusations. In 1900 the Kaiser himself accused the firm of gaining money by excessive prices. He was impulsive and erratic, especially in regard to foreign policy and foreign trade relations. Within a couple of years Wilhelm II changed his policy towards China. While in 1897 he had backed Krupp's intensive trade with China, in 1900 he judged the situation completely differently. In preparation of a punitive expedition against the Chinese rebels, the erratic monarch received information that Krupp took excessive revenues from his armament deals with the German army. On July 111900 he sent a telegram to Friedrich Alfred Krupp: »At this moment when I am about to send my soldiers into war against the Yellow Peril it is inappropriate to gain from it and would be condemned by the public. «(HA Krupp, FAH 3 B 35, published in: Epkenhans/Stremmel 2010: 325). After some efforts the firm was successful in removing these doubts, but nevertheless Friedrich Alfred was personally targeted by the monarch's accusations. The crucial point here is that Wil- 
helm II played the public off against his loyal subject Friedrich Alfred Krupp. Suggesting that Krupp and his firm could compromise state interest in a public discussion about its »unscrupulous pricing policy« during a »patriotic war in China « made clear that the monarch was willing to apply pressure.

At this time Friedrich Alfred Krupp was a mere sport of the monarch's court, the state bureaucracy, competitive firms and the press. In the media any attack by the Social Democrats against »capitalist Krupp« was eagerly picked up. The board of directors was upset regarding this »incredible agitation « but did not strategically know how to react (cf. Wolbring 2000: 278306). Friedrich Alfred Krupp, who became more and more the center of negative attention, drew his own conclusions and withdrew more and more from the public. In 1900 he moved to Capri for several months but nevertheless kept contact with the firm in Essen (cf. Richter 2010: 160). We can find an impression of this atmosphere heated by the press and political intrigues in Berlin in a letter by Admiral Friedrich Hollmann to Friedrich Alfred Krupp, who analyzed the situation at court and the erratic foreign policy of the Kaiser during the Boxer Rebellion:

»The relations between his Majesty and the state bureaucracy on one side and Friedrich Krupp on the other have come to a crisis, so that any new discussion should be handled very carefully. Regarding Krupp it has to be considered that any of his fierce enemies will take the slightest opportunity to forge a weapon for his Majesty to strike against Friedrich Krupp.« (HA Krupp, FAH 3 C 233, published in: Epkenhans/ Stremmel 2010: 325-326)

\section{Hideaway CapRI}

With his stay at Capri over several months Friedrich Alfred Krupp tried to evade the public eye. His health, not just the press attacks, was a concern. While living on this Mediterranean island he pursued deep sea research as a hobby and made friends with the island's inhabitants. But he also supported the local community. He became particularly famous for the construction of a road - the Via Krupp - which he commissioned between 1900 and 1902, a road that was, however, quite useless for the inhabitants. While Krupp occupied himself with marine research and enjoying his spare time, there was a domestic conflict brewing up in Essen. At the beginning of 1902 a strike took place at the firm's forges. It was caused by a quarrel about the duration 
of the mid-day breaks and the calculation of the working hours. 600 workers declared their solidarity with some master-craftsmen who were transferred for disciplinary reasons. All of them left their workplace. Upon their return they received their discharge papers and were attended by two policemen. This homemade trouble was eagerly observed by the press. Friedrich Alfred felt himself compelled to reprimand his board of directors for this strict punishment. According to Krupp they made it easy for the agitators to show themselves, apparently legitimately, as the »representatives of my workforce « (Tenfelde 1994: 30). On 27 February 1902 the social democratic Vorwärts attacked Friedrich Alfred Krupp and accused him of being as »rich and splendid as Croesus « while neglecting to support his workers in Essen (Stremmel 2010: 59-60). Other papers joined in these accusations. Due to these attacks the workforce was tempted to declare its solidarity with the social democrats.

On 6 May 1902 the social democratic Wahre Jacob published a caricature in which it forged a bridge from the strike in the forge to Krupp's role as a benefactor on Capri. In his caricature the draughtsman Rata Langa (18651937) confronted the »two faces of capitalism«. In Essen he was a coldly calculating capitalist exploiting the workers; in Italy he was a benefactor throwing money into the crowd. While workers were squeezed to blood in dark workshops, in Capri lazy clergymen and clerks profited from Krupp the benefactor. Langa made his caricature a universal metaphor which everyone could understand. It is the story of good against evil; strong against weak. The press, with the Wahre Jacob spearheading the satirical magazines, focused deliberately on »Krupp and Capri« - all the more because no one really understood why Germany's wealthiest man retired from public for several months and rode his hobbyhorses on an Italian island. According to the logic of the social democratic press his money, which was squeezed out of protestant workers, was spent on catholics. This brought the affair to cli$\max$. 
Figure 8: „Zwei Bilder aus dem Leben eines

Wohltäters der Menschheit«

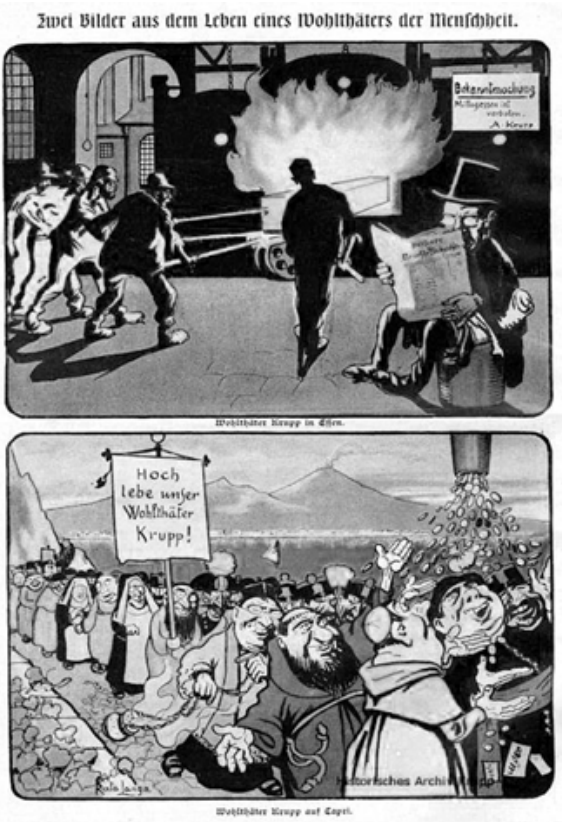

Source: Journal »Der wahre Jacob«, 6.5.1902, lithographic print Institut für Zeitungsforschung, Dortmund

Until that time all the attacks had been aimed at the failures of the Krupp firm. The caricaturists had taken the owner as a personification of his firm. But at the moment when Krupp decided to withdraw from public life and move to a Mediterranean island, the public questioned his personal credibility. The integrity of Germany's wealthiest man grew worn. Therefore the caricaturists took up Capri as a new motive. It enabled them to discredit not only the firm, but its owner Krupp in a most personal way as well.

\section{THE CARICATURE AS A WEAPON}

All satirical papers thought it decisive to attack Friedrich Alfred Krupp in his role as the company's owner. In contrast to his father Alfred - who was seen as an ascetic dedicated to his firm - his son was perceived as a model capitalist. In addition to that he had a different physiognomy. Germany's wealth- 
iest man was fat and the caricaturists singled out this feature in order to describe his character as someone who never worked himself and let others work for him. In the eyes of the social democrats he was a born capitalist. The American historian Harold James comments on these accusations from 1902 as follows:

»In facing a long and vicious campaign with its whole range of scandal and sensation he proved in the end he appeared vulnerable, defenceless to the highest degree.« (James 2011: 129)

As owner of the firm Friedrich Alfred Krupp is last but not least described as a capitalist in order to point out conflicts between different classes. Readers of the social democratic papers were obliged to believe in two opposing truths: On one side the reckless capitalist feeding on the work of his labourers, on the other side the flawless labourer, who is too weak to oppose (cf. Hickethier 1979). These caricatures are based on this dichotomy. The more it highlights these extremes and the conflict of poor vs. rich, the more the public will laugh. It is, however, a laugh of despair which arises from a quite absurd situation. The exaggerated situation provokes emotions in the viewer, be it anger or disgust. The caricaturist has achieved his aim when he causes such as reaction. A political caricature never only aims at entertainment or making the viewer laugh. Its intention is to animate the public towards political action. According to this idea, the caricature of Krupp in the social democratic publication Wahre Jacob was like a call to join the unions and the social democrats in their aims and protests.

The attacks of the press against the Krupp company and its owner grew harder around 1900. The drawings and their impetus grew more and more aggressive. The grotesque allusions to characteristics became something really cutting. The aggressiveness of the satirical magazines competed with the growing influence of the new medium of photography. It forced the caricaturists to develop new perspectives and to be more offensive in regard to capitalism. At the beginning of the $20^{\text {th }}$ century a change took place in regard to visual representation in the illustrated magazines. More and more »dynamic press-pictures « joined the serious press illustrations and took their place. The attacks of the social democratic press evoked no solidarity from the Krupp workers. Until the 1890s the firm was cautious to avoid the influence of the unions and their allies. These rigid measures were initiated by Alfred Krupp, who was very aware regarding his paternalistic regime. He wrote to his management on 10 October 1871: 
»We want to have faithful workers, who are thankful in their hearts and in their actions, so we will give them bread and care for their families. Nobody should dare to oppose our benevolent regime.«(Gall 2000: 188-189)

It was Alfred who initiated draconian measures against readers of social democratic literature and papers. Parts of the press were critical of this rigid policy of the patriarch. The Tremonia wrote on 15 May 1877: »Mr. Krupp turns increasingly into a potentate.«(HA Krupp, WA 41/1.78). However, this was a paper from Dortmund, one of the towns with steel factories which stood in competition with Krupp. In Essen the press was less critical of - one could even say dependent on - the firm.

After criticism from within and from the press Friedrich Alfred took his own measures. The firm set up a bureau for public affairs and began to systematically collect articles and other related material in order to analyse them. To get nearer to his workforce, in 1897 Friedrich Alfred took a desk close to the workshops in the original company building. Here he read letters addressed to him by his employees and workers and could take care of their concerns and criticisms (cf. Stremmel 2010: 60). Friedrich Alfred massively improved the system of labour welfare and spent money to improve his workers' education. In order to bind devoted workers and employees to him he got a step further in 1902. In appreciation of their lifelong work he awarded a badge of honour (»Ehrennadel«). No later than during the lifetime of Friedrich Alfred Krupp the term »Kruppianer« took root within the core workforce (cf. Stremmel 2010: 60) - evidence for a kind of corporate identity. From birth to death the workforce had its own charity at their disposal. But to use it they had to abstain from any criticism. Friedrich Alfred stuck to his patriarchal point of view. He was the unquestioned leader of the firm.

\section{THE SHIELD OF THE EMPEROR}

Friedrich Alfred Krupp died on 22 November 1902 in Essen. His sudden death is closely connected with a press affair and there was an ongoing rumour about a suicide. His doctors in contrast attested a crippling stroke: »Es bestanden die Symptome eines schweren Gehirnschlags... Nachmittags 3 Uhr trat der Tod ein«. An article published on 15 November by the social democratic magazine Vorwärts immediately grew into a scandal. The magazine openly questioned Krupp's immoral and luxurious lifestyle and claimed that he had sexual intercourse with young men in his villa on Capri (cf. 
Wolbring 2000: 316). According to the moral standards of the Wilhelmian society this was no less than social death. But from our point of view we are only interested in the consequences of the press scandal, since the Vorwärts chose an article, not a caricature for its accusations. To publicly abuse Germany's richest man, with his close connections to the Emperor Wilhelm II, provoked specific reactions from conservatives. None other than Wilhelm II took the lead in defence and travelled to Essen in order to participate in the funeral. The whole court followed the coffin through the city, openly showing support of the Krupp family. Upon his departure at Essen railway station Wilhelm delivered a flamboyant speech. »The shield of the German Emperor will protect the family and the memory of the deceased." (Ansprachen anlässlich der Trauerfeier; Grütter 2012, 31). He chose the metaphor deliberately in order to protect his subjects against press campaigns. At the same time he attacked the Social Democrats who had abused the entrepreneur in a most disgusting way. His speech reached a climax when he said: »Everyone who does not tear the tablecloth between himself and the attacking side makes himself guilty." (Ansprachen anlässlich der Trauerfeier; Grütter 2012, 33). This so-called »Tablecloth-Speech« found great response in the press. It was the Generalanzeiger from Essen which condemned the attacks of the Vorwärts:

»The German Emperor himself has raised his shield over the Krupp family and its memory. All Germans stand at his side, he who has found in a deep crisis the right words for the incident. [...] His words make undoubtedly clear that we will never again allow the poisoning of public life as unfortunately happened at other places.« (Klein/Hehemann 1903: 70)

The »Vorwärts-affair « sheds light on the poisoned culture of discussion between the bourgeois right and the social democratic left. Articles and caricatures were regarded as an attack against public order and demagogic class struggle. For the conservatives this was somewhat crossing the line in public debate. Thus the burial in Essen was not only a family affair, but also a kind of public demonstration of state power. For the Kaiser as well as the trade associations it was an occasion to rally against the Social Democrats - who had actually set off the campaign in the Vorwärts. In any case the burial and its ceremonies in November 1902 can be seen as a political statement of conservatives and industrial leaders and their attempt to incite the labour force against the Social Democrats. Therefore the trade unions set up a pompous commemoration service for the Krupp family in Düsseldorf. The 
Kaisersaal of the municipal Tonhalle was adorned with mourning band. For the memorial a tombstone was designed with a clear statement: It shows a knight holding a protective shield above the deceased. On its side the tombstone shows Friedrich Alfred Krupp himself in high relief together with the firm signet, the three rings. No matter that he was already buried in presence of Wilhelm II in Essen. What mattered was the message: to make it unmistakably clear to the public that it was the Emperor who had the privilege of bearing the shield. But in reality his protection came too late for Friedrich Alfred Krupp, one of his subjects. Wilhelm II failed in his role as a protector. Although he could not prevent the attack, he nevertheless offered his shield to the Krupp family and the »memory of the deceased «. This shield was a kind of »firewall «, a protection against the virtual attacks of articles or caricatures. However, this medieval concept of »shield « was outdated and the remarks of Wilhelm II were of no use in bridging the increasing gap between different social groups. On the contrary his aggressive speech at Essen even made the situation worse.

Figure 9: Concept for a grave

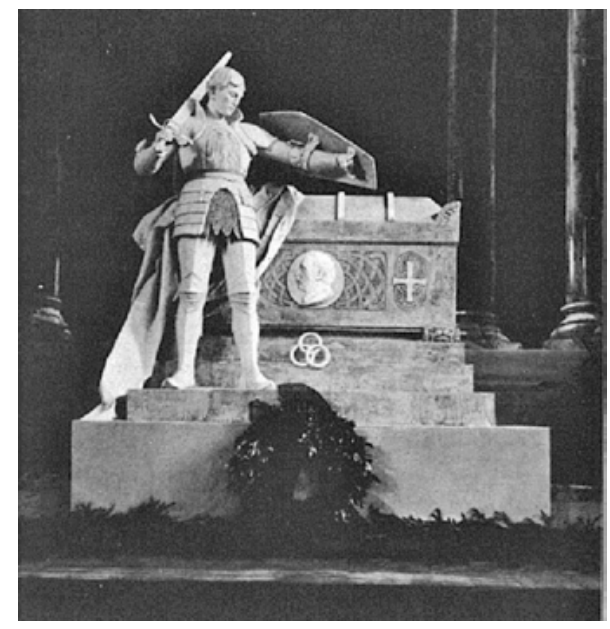

Source: Journal »Stahl und Eisen«, Düsseldorf 1902, lithographic print Dr. Stefan Siemer, Essen 


\section{THE STOCK COMPANY}

Friedrich Alfred Krupp had no male heirs and declared in his will that his firm should be changed into a joint-stock company. At her age of majority in 1903 his firstborn daughter Bertha inherited nearly all of the stock and became owner of the firm. Meanwhile her mother Margarethe acted as head of the family. Despite her marriage with Gustav von Bohlen und Halbach in 1906, Bertha remained the firm's owner. At this time all the newspapers were still interested in Krupp as Germany's biggest weapons manufacturer. But their caricaturists had no idea how to react to the new situation. Due to the new joint-stock structure, there was literally no head of the firm against whom they could launch their assaults. Shortly before the First World War only one incident put Krupp into the public light. In celebration of the company's centenary the English Punch published a caricature. Symbolized as an organ played by the Kaiser, the firm was a willing instrument for fulfilling his intentions. The 1912 centenary took place in Essen with participation of the Kaiser and his ministers and was held with all necessary pomp and circumstance. But only one year later the so-called Kornwalzer affair happened, a corruption scandal comprehensively covered by the press. The company was accused of having bribed clerks in the Ministry of Defence in order to gain secret information. Following that incident the press kept an eye on Krupp in order to attack the close relationship between politics (the military) and the economy (Krupp). 
Figure 10: »Harmony«

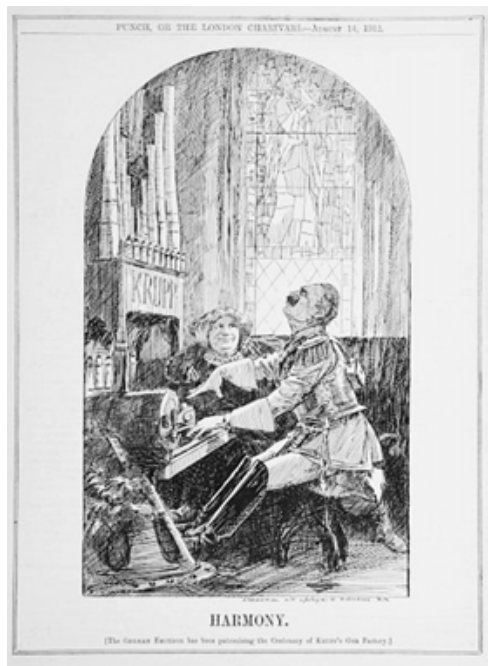

Source: Journal »The Punch«, 16.8.1912, lithographic print Ruhr Museum, Essen

At the beginning of the First World War caricatures of Krupp took a different direction. New weapons like the »Krupp-42cm-Steilfeuergeschütz«, nicknamed »Dicke Berta«, achieved immediate success and led the public into a kind of collective hysteria. But during the war the propaganda used such stories deliberately differently. The rhetoric of warfare after 1914 was completely different from the papers' attacks at the turn of the century. These attacks culminated with the sudden death of Friedrich Alfred Krupp in 1902. None of the subsequent owners and directors would ever act as a target of satire in the papers in the same way as Alfred and especially Friedrich Alfred Krupp. 


\section{ARCHIVES}

Historisches Archiv Krupp, Essen (HA Krupp)

\section{LITERATURE}

Alfried Krupp von Bohlen und Halbach-Stiftung (ed.) (2011): Krupp - Fotografien aus zwei Jahrhunderten, Berlin: Deutscher Kunstverlag. Ansprachen anlässlich der Trauerfeier für Herrn F. A. Krupp, Essen [1903]. Beyer, Burkhard (2007): Vom Tiegelstahl zum Kruppstahl. Technik- und Unternehmensgeschichte der Gussstahlfabrik von Friedrich Krupp in der ersten Hälfte des 19. Jahrhunderts, Essen: Klartext Verlag.

Epkenhans, Michael (2010): »Friedrich Alfred Krupp: Ein Großindustrieller im Spannungsfeld von Firmeninteresse und Politik «. In: Michael Epkenhans/Ralf Stremmel (eds.): Friedrich Alfred Krupp. Ein Unternehmer im Kaiserreich, München: Beck, 77-130.

Epkenhans, Michael/Ralf Stremmel (eds.) (2010): Friedrich Alfred Krupp. Ein Unternehmer im Kaiserreich, München: Beck.

Gall, Lothar (2000): Krupp. Der Aufstieg eines Industrieimperiums, Berlin: Siedler.

Gall, Lothar (ed.) (2002): Krupp im 20. Jahrhundert. Die Geschichte des Unternehmens vom Ersten Weltkrieg bis zur Gründung der Stiftung, Berlin: Siedler.

Grütter, Heinrich Theodor (ed.) (2012): 200 Jahre Krupp. Ein Mythos wird besichtigt, Essen: Klartext Verlag.

Grütter, Heinrich Theodor (2012): »Friedrich Alfred Krupp«. In: Heinrich Theodor Grütter (ed.): 200 Jahre Krupp. Ein Mythos wird besichtigt, Essen: Klartext Verlag, 74-81.

Heimsoth, Axel (2012a) : »Friedrich Krupp«. In: Heinrich Theodor Grütter (ed.): 200 Jahre Krupp. Ein Mythos wird besichtigt, Essen: Klartext Verlag, 64-67.

Heimsoth, Axel (2012b): »Zu Gast in der Welt - Welt- und Gewerbeausstellungen«. In: Heinrich Theodor Grütter (ed.): 200 Jahre Krupp. Ein Mythos wird besichtigt, Essen: Klartext Verlag, 232-243.

Heimsoth, Axel (2013): »Alfred Krupp und die Eisenbahn. Produktion und Marketing im 19. Jahrhundert«. In: Märkisches Jahrbuch für Geschichte, 113. Bd., 153-185. 
Hickethier, Knut (1979): »Karikatur, Allegorie und Bilderfolge - zur Bildpublizistik im Dienste der Arbeiterbewegung «. In: Peter von Rüden (ed.): Beiträge zur Kulturgeschichte der deutschen Arbeiterbewegung 18481918, Frankfurt a. M.: Büchergilde Gutenberg, 79-165.

James, Harold (2011): Krupp. Deutsche Legende und globales Unternehmen, München: Beck.

Kerner, Frank (2012): »Die Welt zu Gast auf dem Hügel. Von Kaiser Wilhelm bis zu Andy Warhol«. In: Heinrich Theodor Grütter (ed.): $200 \mathrm{Jah}$ re Krupp. Ein Mythos wird besichtigt, Essen: Klartext Verlag, 208-231.

Klein, Wilhelm/Max Hehemann (eds.) (1903): Friedrich Alfred Krupp. Eine Gedächtnisschrift, 2. Auflage, Essen: Thaden \& Schmemann.

Köhne-Lindenlaub, Renate (1982): »Krupp«. In: Neue Deutsche Biographie, $13,128-145$.

Richter, Dieter (2010): »Friedrich Alfred Krupp auf Capri. Ein Skandal und seine Geschichte «In: Michael Epkenhans/Ralf Stremmel (eds.): Friedrich Alfred Krupp. Ein Unternehmer im Kaiserreich, München: Beck, 157-177.

Stremmel, Ralf (2006): »Unternehmensziel Bildung. Der Kruppsche Bildungsverein als Sonderfall? «In: Essener Beiträge 119, 239-262.

Stremmel, Ralf (2010): »Friedrich Krupp: Handeln und Selbstverständnis eines Unternehmers«. In: Michael Epkenhans/Ralf Stremmel (eds.): Friedrich Alfred Krupp. Ein Unternehmer im Kaiserreich, München: Beck, 27-75.

Tenfelde, Klaus (1994): »Krupp - der Aufstieg eines deutschen Weltkonzerns «. In: Klaus Tenfelde (ed.): Bilder von Krupp. Fotografie und Geschichte im Industriezeitalter, München: Beck, 13-39.

Wolbring, Barbara (2000): Krupp und die Öffentlichkeit im 19. Jahrhundert. Selbstdarstellung, öffentliche Wahrnehmung und gesellschaftliche Kommunikation, München: Beck.

Wuttke, Ingo (2012): »Die Firma - Von der Gussstahlfabrik zum ThyssenKrupp Konzern«. In: Heinrich Theodor Grütter (ed.): 200 Jahre Krupp. Ein Mythos wird besichtigt, Essen: Klartext Verlag, 126-159.

Zolper, Andreas (2012): »Dämon Krupp«. In: Heinrich Theodor Grütter (ed.): 200 Jahre Krupp. Ein Mythos wird besichtigt, Essen: Klartext Verlag, 34-41. 



\section{Letting Loose the Doggerel of War}

\section{Humorous and Satirical Journals in Britain, France and}

Germany 1914-1918

LESLEY MILNE

Close in the wake of capering Time

I pant and still I pant in vain;

I cannot catch him in a rhyme

Nor snapshot in a passing strain.

»Plaint of a topical bard «,

Punch, 25 December 1918

This essay surveys aspects of the First World War as »fought « in the leading humorous/satirical journals of Britain, France, and Germany, represented by the journals Punch, Le Rire and Simplicissimus respectively. Cartoons and drawings are often used by historians because they condense a complex idea into one striking visual image, but the focus here will be on verbal humour, specifically light verse, or »doggerel «, because these forms of written text can also, as the epigraph above suggests, provide a memorable snapshot, capturing a moment in a line or rhyme in the same way as a cartoonist does in a drawing. A pictorial image from Punch's Almanack for 1915, which was published in December 1914, highlights this role of verbal humour. 
Figure 1: »Punch«Declares Intent to Hound the Enemy in Comic Verse

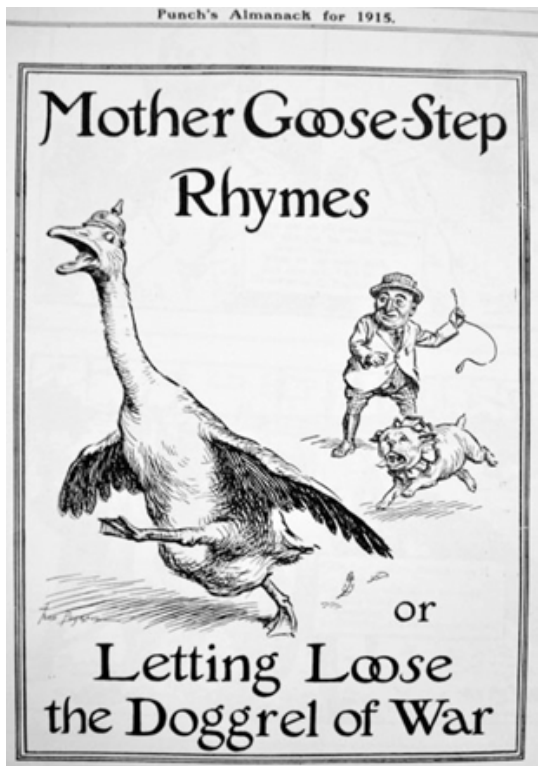

Source: Punch's Almanack for 1915

(Reproduced with the permission of Punch Limited)

Mr Punch unleashes his faithful dog Toby in a deliberate misquotation from Shakespeare's Julius Caesar (where the phrase is »let slip the dogs of war «), while Mother Goose, associated with fairy-tales, nursery rhymes and the British pantomime tradition, is co-opted into the mockery of the German marching step and pointed helmet.

Laughter is most often deployed today to decry the very idea of war, which is regarded as a failure to resolve conflict by other means. But when war is engaged, it is perceived by those who fight as something that »has to be done «, and in this context laughter becomes an adjunct of war, a coping mechanism for soldiers and societies under stress. World War I was a total war, mobilising all available resources of combatants and civilians alike, a context that intensifies every function of humour. Mocking laughter asserts superiority over the enemy, but can also mask secret anxieties and fears. The incongruity that so often provokes laughter can be found at every step, as war-time ways jostle with the remembered modes of peace-time. Irony comes into play as a means of reconciling incompatible forces at their most extreme, matters of life and death becoming everyday reality. Laughter is a 
release, a safety-valve for suppressed emotions, while at the same time insulating and anaesthetising against both pity and horror. In its social function as a corrective to undesirable behaviour, laughter is deployed against those who are viewed as offending against the patriotic consensus. Within the consensus, laughter promotes social cohesion, raising the spirits and helping to maintain morale. The years 1914-1918 were a historical watershed, the world's first experience of industrialised carnage. After that, in the words of Philip Larkin's poem MCMXIV, there was »never such innocence again«. The aim of this study is to assist our imaginative understanding of the wartime mentalities in a conflict that is so relatively near to us in historical time and yet so very distant from us, across that great watershed of historical trauma.

The three selected journals were all published weekly, with both cartoons and written contributions: sketches, stories, quips, and verse. Punch was an old-established satirical review that had been founded in 1841, on the model of the French Charivari, as indicated by its subtitle: Punch, or the London Charivari. The name Punch referred to the rowdy puppet of the Punch and Judy show, but by the 1900s Punch had become an institution, part of the establishment, Mr Punch himself acquiring in the illustrations a respectably bourgeois aspect, albeit still with a twinkle of mischief in his eye. Punch represented the world of the leisured middle or upwardly middle classes, its ethos that of the public school and sport, with its codified rules of behaviour and fair play. Le Rire, founded in 1894, belongs to a different tradition of humorous illustrated journalism. In France censorship had been lifted from drawings in 1881, which gave freedom to treat light and risqué subjects (cf. Histoire générale de la presse française 1972: 385). In its title Le Rire offered quite simply »Laughter « and represented an image of Paris as the city of gaiety, its ethos that of the »belle époque «, the two-decade golden age of peace, prosperity and pleasure that came to an end in 1914. There was a break in the journal's publication between 1 August and 21 November 1914, when production was disrupted by mobilisation of the totality of the male population fit and of age to bear arms (those between 20 and 40), which emptied the printing works and editorial offices. When the journal resumed, it was under the war-time title of Le Rire Rouge, »red « indicating martial rather than politically radical intent. Targeted on an urban and urbane readership, it continued with its traditional themes and stock situations, but now in military uniform (cf. Lethève 1961: 165). Simplicissimus was founded in 1896, its mission to restore sharpness and radicalism to humorous-satirical journalism in Germany. The journal took its title from the novel of the same 
name by Grimmelshausen, published in 1669 and set in the Thirty Years' War, where the simpleton narrator observes the grotesque depravities of the warring armies. Satire in the journal was aggressive, symbolized by its chosen mascot, a red, belligerent bulldog. Published in Munich, one of the magnet cultural cities of the time, Simplicissimus boasted a cosmopolitan array of artists and quickly secured an international reputation. As befitted its title it was strongly anti-militarist, right up to the summer of 1914, and when war broke out it was faced with a dilemma. However, along with the German Social Democratic Party, it took the decision to support the »Burgfrieden «a truce among the social and political factions to ward off the external threat. During the war, according to a contemporary, the journal expressed the opinions and tendencies across a wide spectrum of educated German public (cf. Avenarius 1972: 221-222).

Punch, Le Rire and Simplicissimus all lent their unstinting support to the national war effort in their respective countries, and were, to that extent, organs of governmental propaganda. However, as Christopher Clark has explained, in each country there was a mood of »defensive patriotism, for the aetiology of this conflict was so complex and strange that it allowed soldiers and civilians in all the belligerent states to be confident that theirs was a war of defence, that their countries had been attacked or provoked by a determined enemy « (Clark 2012: 553). The war was thus perceived on all sides as a war of national survival, and it has been pointed out that in such a situation people might be perfectly aware that they were being propagandised, but not actually care; they wished to believe the best of themselves and the worst of the enemy. The key was that the propaganda had to be credible and not too much (cf. Bourne 2001: 47-48).

Humour, of course, is an excellent vehicle for such propaganda. Among the various functions of humour as deployed by societies under stress, the most basic is the need to dispel fear. This was identified by Le Rire in early November 1918 on the topic of Spanish flu (which reached its apogee in France in October 1918, when there were 200,000 deaths, half of whom were soldiers). The journal mentioned that »la grippe espagnole « was being joked about in song and cartoon because "people don't want to be afraid of it « (on ne veut pas en avoir peur). Each journal met this same human need: in circumstances that most people could do nothing about, they wanted to laugh so as not to be afraid. This was vital for the maintenance of morale, the role that the journals formulated for themselves in order to justify their continued existence as purveyors of laughter while the nation was engaged in the stern task of war. 
Each journal adopted an attitude of defiance. The mode of Punch is defiant levity, subsequently defined in Mr Punch's History of the Great War as »that peculiar and blessed birth-right which enables [an Englishman] to overthrow the Giant Despair with the weapon of whimsical humour« (231). For Le Rire the mode of defiance is constantly affirmed as Gallic gaîté, again seen as part of a national birth-right. The laughter of Simplicissimus is that of defiant challenge, against encirclement by a whole world of enemies but specifically against Britain (almost always, however, referred to as »England «); this is challenge to the old order, the old empire that seeks to deny the new young nation its rightful »place in the sun «.

Expressing in comic form the language of national pride and defiance of the enemy, the journals continued an ancient tradition: that of »flyting «, the word commonly used in English scholarship to refer to the stylized boastinsult contests found throughout Norse literature. The tradition has been summarised as follows: »The flyting is [...] a >voice war८, and the disputants [are] >word warriors $«$ or >speech champions « (Clover 1987: 172-173). There is a parody of flyting in the film Monty Python and the Holy Grail (a fine example of history and humour). In an early scene, King Arthur and the Knights of the Round Table approach a castle held by the French, who shout insults, such as »I wave my private parts at your aunties « and »I fart in your general direction «. The insults are effective, forcing Arthur and his knights into bewildered retreat. An echo of flyting survives in living traditions, such as football chants, for instance the famous boast of the Millwall supporters: »Nobody likes us, and we don't care«. Interestingly, this obeys a central rule of flyting, which is that $»$ the facts are not disputed, but their importance is diminished « (Clover 1987: 174). It may be a fact that »nobody likes us «, but that is not important because »we don't care«. The rule that facts are not contested but instead are deflected or diminished has a classical antecedent. Herodotus in his Histories relates the anecdote of a Spartan soldier at the Battle of Thermopylae who, when told of the Persian boast that their arrows would block out the sun, responded: »Then we shall fight in the shade «. The acceptance of a threat, boast or insult in order to diminish its significance thus has a long lineage as a device for sustaining morale in the face of military hazard.

Acceptance of an enemy's boast can be seen in $\gg$ The Cockerel on the Bell-tower « (Le Coq du clocher), which appeared in Le Rire on 8 May 1915, referring to the German conquest of Belgium and the German flag flying on the cathedral of Notre Dame in Antwerp. A passing German proudly observes: »That's my flag you see up there, / Und über alles the most fair « 
(Cela, monsieur, c'est mon drapeau, / Und über alles le plus beau). The Belgian rejoinder acknowledges the presence of the flag, but continues:

But you in turn must now admit

The only place you've found for it Is right beneath our ancient cock

Staunch and solid as a rock.

As he cannot come down from there,

Upon my soul, I do declare,

Without a pot, and here's the snag, He'll do his business on your flag!
Mais veuillez aussi reconnaître

Que celui-ci n'a pu se mettre

Qu'au-dessous de notre vieux coq,

Solide au poste comme un roc.

Jamais on ne le vit descendre,

Et c'est ennuyeux, à tout prendre,

N'est-ce pas? N'ayant pas de pot,

Il doit faire sur ton drapeau!

In other words: yes, the flag is there, but not quite über alles; the cockerel (emblem of France) is still up there with ammunition to dump on German pride.

One German example that expresses the essence of flyting, in its language of national pride and defiance, is the »Hymn of Hate against England « (Haßgesang gegen England), written by Ernst Lissauer. In its opening lines the poem states that for the French and the Russians there is neither love nor hate: it is simply a matter of holding the borders against them. The rest of the poem affirms and reaffirms in its refrain: $» W e$ have all but a single hate, / We love as one, we hate as one, / We have one foe and one alone - England! « (Wir haben nur einen einzigen $\mathrm{Ha} \beta$, / Wir lieben vereint, wir hassen vereint, / Wir haben nur einen einzigen Feind: England!; Lissauer, tr. Henderson 1915). Lissauer also created the phrase »God punish England « (Gott strafe England). This Hymn of Hate and the slogan were obvious targets for satirists on the Allied side. The British armies, with stoical acceptance, jokingly diminished the morning and evening bombardments by referring to them as »the morning hate« and »the evening hate«. This hatred fixed solely on England seems to take France slightly aback, however. On 23 January 1915 we find Le Rire in its survey of the week ironising over the »francomania « in Germany: »All right, concession for concession: [...] We do not detest Austria. [...] We haven't the time. And she is so insignificant anyway!« (Eh bien, concession pour concession: [...] Nous ne détestons pas l'Autriche. [...] Nous n'avons pas le temps. Et puis, elle est si insignifiante!). This suggests a suspicion that France also is being viewed as insignificant, and the focus on England as sole enemy can therefore be interpreted as an insult to France. The insult, however, was avenged in a satirical chanson »Dieu punisse l'Angleterre!«, published in Le Rire on 7 August 1915: 
If the Boche is out a-walking and A brick falls on his bonce, »This is all the fault of England «, Is the German's first response. Not seeking further explanation For his each and every pain »God punish the English nation«, Is the German's sole refrain.

Are his feet cold?

Do his teeth hurt?

Is his chair hard?

Is he dying of thirst?

Has he lost his

Shirt-collar stud?

Did he forget

To turn off the gas

Before leaving the house?

Every hitch in his day

Translates by this one Imprecation:

- May God punish England!

\section{$[\ldots]$}

If his pipe is stuffed with herbage And his butter tastes all wrong, And his bread's all crap and garbage, Always it's the same old song; When he's sick of food that's ersatz, And his stomach moans and wails, It's »God punish England! « that's The rumble of his entrails.

From duodenum

To jejunum,

From pancreas

Into pylorus,

Down through the nooks

Of digestive loops;

The colon next groans
Quand le Boche sur la têtère

D'une tuile reçoit un coup,

C'est de la faute à l'Angleterre;

L'Angleterre est cause de tout.

Sans vouloir percer le mystère

De ses moindres désagréments,

C'est »Dieu punisse l'Angleterre! «

Le refrain de tout Allemand.

A-t-il froid aux pieds?

Souffre-t-il des dents?

Est-il-mal assis?

Crève-t-il de soif?

A-t-il perdu son

Bouton de faux-col?

A-t-il-oublié

De fermer son gaz

Avant de partir?

Chaque ennui qu'il a

Se traduit par cette

Imprécation:

- Que le Vieux-Dieu punisse

l'Angleterre!

\section{$[\ldots]$}

S'il ne fume pas sa bouffarde

Et si son beurre a goût de suif,

Si sa table s'empainkakarde,

C'est toujours l'Anglais qu'est fautif.

De sa misère alimentaire

Quand son ventre se plaint tout haut

C'est »Dieu punisse l'Angleterre! «

Qui court le long ses boyaux.

Du duodénum

Dans le jéjunum

Du pancréas au

Pylore aussitôt,

Dans tous les recoins

Des deux intestins,

Dans le coecum creux 
»God«, upon which

A »punish« intones

From the appendix;

And from sphincter the grand

Finale: »Eng-land! «...

- May God punish England!

The Boche in bed with his missus

His limbs stretches out beside hers,

And their mouths seek with their kisses

To light the fire that stirs.

Alas, no passion ignites it,

He's tired, and torpor prevails;

So to rouse himself he recites it,

The mantra that never fails:

- May God punish

.ay God punish

..y God punish

... God punish

... .od punish

.....d punish

......punish

...... unish

....... nish

........ish

.........sh

...........h!

- May God punish England!
On entend »Que Dieu«,

À quoi l'appendice

Ajoute »punisse «,

Enfin le sphincter

Conclut $» l$ 'Angleterre «...

- Que le Vieux-Dieu punisse l'Angleterre!

Le Boche, le soir, dans sa couche S'allonge auprès de sa Gretchen,

Et pour s'allumer leurs deux bouches

Se font des ... delikatessen.

Hélas! morte semble la bête!..

Il est vaseux, c'est énervant!.

Et pour s'exciter il répète

Jusqu'à ce qu'il soit triumphant:

- Le Vieux-Dieu punisse

.e Vieux-Dieu punisse

..Vieux-Dieu punisse

...ieux-Dieu punisse

....eux-Dieu punisse

.....ux-Dieu punisse

......x-Dieu punisse

-Dieu punisse

........Dieu punisse ieu punisse

.........eu punisse

..........u punisse

punisse

- Que le Vieux-Dieu punisse l'Angleterre!

The shape of the last verse here is replicated in the refrain of the English bawdy song »Oh, Sir Jasper!«, suggesting an affinity of form for ribald versification of the sexual act. In Le Rire, the characteristically French genre of the satirical chanson is a constant feature, and this example from August 1915 covers many targets. The mention of gas is not accidental (gas was first used by the German army on the Western front in April 1915). The mockery of the enemy's sexual performance, while one of the traditional flyting mo- 
tifs, here masks anxiety over the declining birth rate in France as compared to the steady pre-war population growth in Germany, a demographic imbalance catastrophically exacerbated by the war, which it was feared would bleed France white (cf. Becker 1985: 6). The verses jeering at the German's upset stomach contain a derisively inventive coinage: the verb s'empainkakarder, which refers to the war-time German »K-brot « (K-bread, K standing for Krieg) - an unfortunate name, because doubling of the $\mathrm{K}$ produces $\mathrm{KaKa}$, and caca is a nursery word in many languages denoting excrement. So the German's war-bread is pain-caca, spelled with the »German« letter k, and his table is thus heaped with crap (or krap): »Si sa table s'empainkakarde...«. The jibe not only affirms French culinary superiority but also, in the context of the war, expresses the hopes pinned upon the naval blockade by Britain, the aim of which was to starve Germany into submission through shortages of food and raw materials.

The blockade, and the battle between »England « and Germany for naval supremacy, is an area where the war of invective reaches its heights. The main focus of taunts, on both sides, was the fact that the British Grand Fleet kept to harbour in the north of Scotland, in Scapa Flow, while the German High Seas Fleet likewise kept to harbour in the Kiel Canal. On 16 February 1916 Punch referred to this in a »Modest Suggestion for a New Hunnish Canticle«, couched as a parody of the British Royal Navy Hymn, with its refrain: »Oh, hear us when we cry to Thee, / For those in peril on the sea!«. In Punch's new German anthem this becomes: »Omnipotence, we need thy hand / In air, on sea, canal and land! « - the word canal mockingly incongruous with the aspirations of a »High Seas « fleet. However, the British Grand Fleet was also keeping to harbour, which exposed it in turn to taunts from the German side. In a witty piece of satirical verse, entitled »The British Sea Lion « (Der britische Seelöwe), published on 11 May 1915, Simplicissimus finds a housewifely metaphor for this hiding in harbour. If you want to preserve something, what do you do? You marinade it. That's why the British have »marinaded their marine « (Drum haben sie [...] ihre Marine mariniert). Meanwhile, the cautious Anglo-Saxon sits »And sings with feeling on the harbour pier, / My heart's in the highlands, my heart's not here « (Und singt gefühlvoll am Hafenpier: / Mein Herz ist im Hochland, mein Herz ist nicht hier).

On 31 May 1916 the British Grand Fleet and the German High Seas Fleet finally clashed, in their only engagement of the war, at the naval battle of Jutland, known in Germany as the Skaggerakschlacht. The British Fleet was commanded by Admiral Jellicoe, of whom Churchill said that he was the 
only man, on either side, who could lose the war in an afternoon. There were 150 ships on the British side, 100 on the German, and the battle was over in a few hours. When a tally of losses was taken, the German fleet had won the day, having sunk 14 British ships, with a loss of only 11 of their own. The Skaggerakschlacht was immediately celebrated in Germany as a victory. In Britain, accustomed to and expecting naval success on the scale of Trafalgar, the battle was not reported until some time after it was over (cf. Ferguson 1998: 235). Had the war indeed been »lost in an afternoon «?

Jutland was not the only blow to Britain at this point. On 5 June Field Marshal Lord Kitchener died when the ship on which he was sailing on a mission to Russia hit a mine. In Simplicissimus, Jutland and the death of Kitchener were brought together on 20 June 1916 in a tour de force of satirical verse, »Nelson und Kitchener«, a dialogue between Nelson and Kitchener in the underworld. The verses as they appeared in the journal were set as three eight-line stanzas, each printed as a block, and with the speakers identified only by context. In the translation given below the lines are split into dramatic dialogue to make the exchanges easier to follow. The names of British ships sunk at Jutland are italicised, and there is a reference to Sir Edward Grey, the British Foreign Secretary.

\begin{tabular}{|c|c|}
\hline NELSON & Whence come you, spirit? \\
\hline KITCHENER & England. \\
\hline NELSON & And so wet? \\
\hline KITCHENER & I took a cooling bath. \\
\hline NELSON & Up there it's hot? \\
\hline KITCHENER & Yes, hot. \\
\hline NELSON & So scant of words? What hide you yet? \\
\hline KITCHENER & The whole world knows the story, so hide what?! \\
\hline NELSON & What, then? \\
\hline KITCHENER & We have ill luck. \\
\hline NELSON & Do you know why? \\
\hline & $\begin{array}{l}\text { Were I not spirit, you should feel my blow. } \\
\text { The public has grown weary of your lie, } \\
\text { And sterling's stock has sunk to all-time low. }\end{array}$ \\
\hline
\end{tabular}

KITCHENER Just like your fleet.

NELSON

What tale is this you tell?

KITCHENER A tale that starts: »Once on a time there was.«

NELSON

Was what? 
KITCHENER

A fleet that was and then it fell.

I join you at the wake for a lost cause.

Queen Mary and Black Prince are to preside

At table where the mourners come to dine;

Sirs Sparrowhawk and Warrior side by side;

Sirs Turbulent and Ardent serve the wine.

Invincible the first toast will propose,

In eloquence a match for Mr Grey -

While Indefatigable flytes his foes.

But soft! I see them come in their array!

NELSON Trafalgar! But why do you rack

Us with this prank at midnight's hour of sleep?

All hands on deck and hoist the Union Jack!

KITCHENER It lies with us in tatters in the deep.

NELSON Woher des Wegs?

KITCHENER

NELSON

Von England.

KITCHENER

NELSON

Und so naß?

Ich nahm ein kaltes Bad.

Ist's droben heiß?

KITCHENER

NELSON

Sehr heiß.

KITCHENER

NELSON

So wortkarg? Ihr verschweigt mir was.

KITCHENER

NELSON

Verschweigen, wo es alle Welt schon weiß!

Was denn?

Wir haben Pech.

Wißt ihr warum?

Wär' ich kein Geist, ich nähm' Euch bei den Ohren.

Mit Lügen langweilt Ihr das Publikum,

Und Euer Sterling hat den Kurs verloren.

KITCHENER Wie Eure Flotte.

NELSON

Kerl, das klingt ja wie -

KITCHENER Ein Märchen, und beginnt: Es war einmal.

NELSON

KITCHENER

NELSON

Was war? Ich bitt' Euch. Was?

Nun eben sie.

Und du?

KITCHENER

Ich komme nur zum Leichenmahl.

Queen Mary mit dem schwarzen Prinzen soll 
Bei Tisch, sagt die Prinzessin, präsidieren.

Herr Krieger kommt und Herr von Schlachtgeroll.

Herr Hitzkopf mit Herrn Sperber wird servieren.

Herr Unbesieglich hält den ersten Toast;

Er redet fast so schön wie Mister Grey -

Drob ist Herr Unermüdlich ganz erbost,

Weil er - doch still! Sie kommen, wie ich seh!

NELSON! Ha! Bei Trafalgar! Sagt, zu welchem Zweck

Der Faschingsulk zu mitternächt'ger Stunde?

Alle Mann auf Deck und hißt den Union-jack!

KITCHENER Er liegt zerfetzt mit uns im Meeresgrunde.

These verses brilliantly capture that moment of German exultation: the humbling of British naval pride at the battle of Jutland. However, although at Jutland the British had lost more ships than had the Germans, the losses did not alter the balance of naval power. Britain still had more ships, 136 as against the German fleet's 89, and could still maintain the blockade. Thus while Germany could and did hail the Skaggerakschlacht as a victory, it was not of strategic significance.

In autumn 1918 Germany was completely unprepared for defeat. Simplicissimus expresses the pain of national tragedy at this point, with particular sympathy for the front-line soldiers who had fought heroically for over four years against a world of enemies. There was, however, a new focus for patriotic aspirations. The overthrow of the Hohenzollern monarchy and the establishment of the Weimar Republic accorded with the journal's pre-war political tradition, and a front-page drawing on 12 November 1918, entitled »Hoffnung «, carried a caption beneath expressing that hope: »The German eagle will drink new strength from freedom's fountain of youth « (Aus dem Jungbrunnen der Freiheit wird der deutsche Adler neue Kräfte trinken). The country, however, was war-weary, internationally isolated, utterly depleted of resources and still in the throes of revolutionary unrest. The front-page drawing on 31 December 1918 entitled »Naked into the New Year« (Nackt ins neue Jahr) showed the German Michel, barefoot in the snow and naked but for a red Phrygian cap and a pair of red underpants. Underneath the drawing are two stanzas of verse: 
Now I am free,

From fabrics and soap and from trusting and hope,

From commerce and trade by sea,

From armchairs and sweaters, punition and fetters,

Religion and clerisy,

From ham and gold rings and from sausage and kings,

And bitterest tyranny

I am now free.

From work and from striving and peaceable living,

From sugar and eggs and tea,

From auspicious star signs and comfort and rail lines

And Fatherland Party,

From arms and befrienders, esteem and defenders,

From Mitteleuropa spree,

I am now free.

Nun bin ich frei,

Von Kleidern und Stoffen und Glauben und Hoffen,

Von Handel und Kauffahrtei,

Von Möbeln und Betten und Strafen und Ketten,

Religion und Klerisei,

Von Schinken und Würsten, von Gold und von Fürsten

Und bitterer Tyrannei

Bin ich jetzt frei.

Nun bin ich frei

Von Arbeit und Streben und ruhigem Leben,

Von Zucker und Fett und Ei.

Von Eisenbahnwagen und Glück und Behagen

Und Vaterlandspartei,

Von Freunden und Stützen und Ruhm und Geschützen,

Von Mittel-Europageschrei

Bin ich jetzt frei.

With its galloping rhythm, inventive rhymes and juxtaposed categories, this is a verbal snapshot using the devices of doggerel to encapsulate a moment of hiatus. The citizen hailing the new republic is rid of monarchical tyranny 
and right-wing expansionist politics, but is bereft of all comfort and certainty.

Throughout the war, from the early advances of August 1914 to late May of 1918, Germany had been able to celebrate repeated military successes. Punch adopted a lofty tone with regard to the German culture of celebration - a disdain that surely masks anxiety at not having cause for similar rejoicing. (The celebratory bells were rung for the first time in Britain after the ballet of Cambrai in November 1917, but the Germans recaptured the ground ten days later; cf. Stevenson 2004: 338-339). When given cause for pride, Punch drew a pointed contrast between German and British behaviour:

We are not good at shouting in the street, At waving flags, or tossing caps in air;

We take our triumphs as we take defeat

With scarce a hint of having turned a hair;

And so our pride today

Declines to boom itself the German way.

The first two lines express scornful superiority over the Germans, who do behave in this, by implication ridiculous, way: The next two lines by way of contrast assert »our « behavioural code. One feature of Punch was its use of metaphors from sport, and these lines contain implicit reference to the sporting ethos of restraint in both victory and defeat. There is also here an echo of Rudyard Kipling's aphorism in his poem If: »If you can meet with triumph or disaster, / And treat these two impostors just the same «. The last two lines of the Punch stanza reaffirm the superiority of this British behavioural code.

What triumph, then, was Punch celebrating with such studied decorum? A specific feature of Punch was that its »leading article « every week was normally in verse, and this poem was the leader on 12 July 1916. It refers therefore to the start of the Battle of the Somme, the opening day of which, 1 July 1916, is universally regarded as $\gg$ the most notorious day in British military history « (Sheffield 2011: 170). »On that day there were 20,000 British dead, and 37,000 other casualties, for almost no gain at all (Stone 2008: 103). So how on earth could this be a cause for pride? Of course, it takes time for the scale and volume of such casualties to become known, and when this issue of Punch went to press, the day would not yet have acquired its notoriety. But in the book Mr Punch's History of the Great War, which collected together the journal's month-by-month mirror of events and was first published in July 1919, we still find the assertion, made even more 
strongly: »The victory, for victory it is, has not been celebrated in the German way. England takes her triumphs as she takes defeats, without a sign of having turned a hair « (107). Mr Punch's History then goes on to quote the second verse, which provides the beginnings of an explanation:

Yet we are proud because at last, at last

We look upon the dawn of our desire;

Because the weary waiting time is passed

And we have tried our temper in the fire;

And proving word by deed,

Have kept the faith we pledged to France at need.

The last two lines of the stanza reflect the fact that the Battle of the Somme was engaged in July 1916 in order to relieve pressure on the French at Verdun (cf. Sheffield 2011: 164, 171, 194). But there is also a wider context. Until 1916, the British had, in comparison with France, very few soldiers in the field. Indeed there were mutterings abroad among allies, and jibes in the enemy press, that the British would fight »to the last Frenchman « (cf. Bourne 2000: 480; Ferro 2002: 151; Simplicissimus, 29 Dec 1914: 513). In the Musée de l'Armée in Paris there is a video projection of troop movements during the Battle of the Marne in September 1914, and any British visitor must be struck by just how tiny the British contingent is in comparison to the long lines of the French armies stretching out on either side. Unlike France and Germany, Britain in 1914 had no compulsory military service. It had a small professional army, and a Territorial Army which it was able to mobilise, but until conscription was introduced in 1916, the British were reliant upon the volunteers who flooded to Lord Kitchener's call to join a new national army. Civilians with no previous military experience at all, they could not be put into the field without training, which took time. The New Army had made a first appearance at Loos, in autumn 1915, but the Somme was its first major offensive: hence the title of the Punch verses, which is: »The Test of Battle«. This was the moment that would demonstrate whether this deeply civilian assortment of men could perform as an army. The answer from the Somme was that they could. Hence the pride, and perhaps relief, that rings out in the third verse:

But most because, from mine and desk and mart, Springing to face a task undreamed before,

Our men, inspired to play their prentice part 
Like soldiers lessoned in the school of war,

True to their breed and name

Went flawless through the fierce baptismal flame.

The first two lines of the stanza evoke the recruitment of this volunteer army from all walks of civilian life. In the third line the words »play their prentice part « emphasise that these men are still apprentices, not yet masters of the art of war. The military historian Gary Sheffield, while refusing to endorse the word »victory « with regard to the Somme, does agree with the »prentice « reference, seeing the British civilian volunteer soldiers of July 1916 as serving their military apprenticeship there and arguing that it was on the Somme from July to the end of the battle in November that the British amateur force took its first steps to becoming the war-winning army of 1918 (cf. Sheffield 2011: 5, 197, 377). Thus, however shocking it is now to find the opening days of the battle of the Somme presented as a cause for pride, the Punch verses do capture that defining moment when the newly formed British national army took to the field »at last, at last«, stoically accepting both triumph and disaster as it »kept the pledge made to France «, and proved itself, sacrificially, in the »baptismal flame « of its first real »test of battle«.

Those British citizen volunteers knew themselves to be amateurs, facing what was regarded as the best military machine in the world. Although the middle-class sporting ethos of the time vaunted the amateurs (the »gentlemen «) over the professionals (the »players «), this assumption of superiority did not necessarily apply to actual warfare, and there was therefore an anxiety inherent in the situation. One staple of the Punch tradition provided a ready-made template to capture such anxiety and provide a means of expression through defensive self-mockery. This was the tale of personal incompetence and misadventure, identified by a historian of Punch as one of the journal's dominating forms since the 1860s (cf. Price 1957: 90, 149). The pre-war genre now adapted to a new context, as in these verses by A.P. Herbert, which appeared in the journal on 18 July 1917 under the title »A Lost Leader «:

The men are marching like the best;

The waggons wind across the lea;

At ten to two we have a rest,

We have a rest at ten to three;

I ride ahead upon my gee

And try to look serene and gay; 
The whole battalion follows me,

And I believe I've lost the way.

Full many a high-class thoroughfare

My erring map does not disclose,

While roads that are not really there

The same elaborately shows;

And whether this is one of those

It needs a clever man to say;

I am not clever, I suppose,

And I believe I've lost the way.

The soldiers sing about their beer;

The wretched road goes on and on;

There ought to be a turning here,

But if there was the thing has gone;

Like some depressed automaton

I ask at each estaminet;

They say, »Tout droit«, and I say »Bon«,

But I believe I've lost the way.

I dare not tell the trustful men;

They think me wonderful and wise;

But where will be the legend when

They get a shock of such a size?

And what about our brave Allies?

They wanted us to fight today;

We were to be a big surprise -

And I believe I've lost the way.

This is high foolery indeed, controlling within the tight form of the light verse a flood of insecurity: the front-line officer leading his »trustful men «, awed and appalled by his own responsibility to them, to »our brave Allies « and ultimately to winning - or losing - the war. Lurking unspoken in the background is the age-old proverbial rhyme about »the want of a horse-shoe nail «, as a result of which the horse, the rider, the battle, and then the kingdom are lost. The Punch verses tread the edge of hysteria, the humour of incompetence shaping the stuff of nightmares and providing release from them. 
British comedy of military incompetence runs through the much-loved TV series Dad's Army to the sit-com 'Allo, 'Allo, set in occupied France during the Second World War. In 'Allo, 'Allo, the British, the French Resistance and the Germans - all alike are bumbling buffoons, the war fading into nonexistence behind the sit-com plot. Some cannot watch 'Allo, 'Allo, seeing in it a travesty of events too terrible for laughter. From another perspective, however, its buffoonery provides release from historical nightmares. It could almost be seen as a gesture of European integration, blessing all sides in the conflict with the same ludicrous incompetence.

Can anything be deduced from these journals about »national « characteristics of humour? It would surely be strange if such a fundamental human response as laughter observed geo-political frontiers within what was, after all, the shared Graeco-Roman / Judaeo-Christian heritage of the educated classes that were the journals' readers and contributors. While it would be true to say that the profile of the journal - each of which served as a model in its respective culture - encouraged humour of a particular type and provided a means of its dissemination, this does not mean that any nation had a monopoly on a specific type of laughter. Le Rire enjoyed latitude to treat risqué topics, but this does not mean there were no sexual or scatological jokes in the other countries; in France they just had greater currency in print. Although in Punch the tale of personal incompetence and misadventure was developed into a journalistic form, it is also a staple joke for clowns and stand-up comedians the world over. Simplicissimus was a literary as well as a satirical magazine, which gave it scope to include serious prose and poetry that in Britain and France would have appeared in other periodicals, but its pages also included virtuoso displays of topical verse. What can be said in summary is that types of laughter depend on circumstances rather than national characteristics; a joke that is a jeer from one side can be the ironic stoicism of gallows humour on the other. The journals used different modes and metaphors, but taken together they express a commonality of experience during the first of the $20^{\text {th }}$ century's great traumas. 


\section{LITERATURE}

\section{Primary sources}

Punch: Magazine volumes online. $<$ https://sites.google.com/site/punchvolumes/>

Simplicissimus: Die historische Satirezeitschrift als Online-Edition. <http://www.simplicissimus.info/>

Le Rire (from 21 November 1914 to 28 December 1918 under the title of Le Rire Rouge): Print edition only.

\section{Secondary sources}

Avernarius, Ferdinand (1972): Das Bild als Narr. New York: Garland Publishing, Inc. Reprint of the original publication (1918), Munich: Georg Callwey.

Becker, Jean-Jacques (1985): The Great War and the French People, tr. Arnold Pomerans, Leamington Spa: Berg.

Bourne, John, Peter Liddle and Ian Whitehead (eds.) (2000): The Great World War 1914-1945. Vol 1. Lightning Strikes Twice, London: HarperCollins.

Bourne, John, Peter Liddle and Ian Whitehead (eds.) (2001): The Great World War 1914-1945. Vol 2. Who Won? Who Lost?, London: HarperCollins.

Clark, Christopher (2012): The Sleepwalkers. How Europe Went to War in 1914, London: Allen Lane.

Clover, Carol J. (1987): »Norse Flyting «. In: Dictionary of the Middle Ages, New York: Charles Scribner's Sons, vol 9, 172-175.

Ferguson, Niall (1998): The Pity of War, London: Allen Lane.

Ferro, Marc (2002): The Great War 1914-1918, tr. Nicole Stone, London: Routledge Classics.

Histoire générale de la presse française, vol. 3: $1871-1940$ (1972), Paris: Presses Universitaires de France.

Lethève, Jacques (1961): La Caricature et la presse sous la III-e République, Paris: Librairie Armand Colin.

Lissauer, Ernst: »Hymn of Hate against England « (Haßgesang gegen England), tr. Barbara Henderson, as it appeared in The New York Times, 15 October 1914.

<http://www.hschamberlain.net/kriegsaufsaetze/hassgesang.html> Accessed 25 January 2013. 
Mr Punch's History of the Great War (2007), Stroud: Nonsuch Publishing Limited.

Price, R.G.G. (1957): A History of »Punch «, London: Collins.

Sheffield, Gary (2011): The Chief: Douglas Haig and the British Army, London: Aurum.

Stevenson, David (2004): 1914-1918. The History of the First World War, London: Penguin Books.

Stone, Norman (2008): World War One. A Short History, London: Penguin Books.

\section{Acknowledgements}

Illustration

Figure 1: »Mother Goose-Step Rhymes« from Punch’s Almanack 1915 Reproduced with the permission of Punch Limited.

A.P. Herbert »A Lost Leader «

Quoted with the permission of AP Watt at United Agents on behalf of the Executors of the Estate of Jocelyn Herbert, MT Perkins and Polly MVR Perkins. 


\section{Poignant Past.}

\section{How Interwar Satirical Magazines in Germany, France and Spain Used History to Criticise Their Times}

LOUISA REICHSTETTER

\section{INTRODUCTION}

In June 1932 El Be Negre, a Barcelona-based satirical magazine, published an unusual edition: only 50 percent was written in Catalan, while the other half was Spanish. The Catalan content harshly criticised the democratic government for reforming the country too slowly and thus delaying the promised regional autonomy for Catalonia; the Spanish counterpart ironically tried to flatter the very same politicians. The last two articles, however, reveal that both positions were subject to an intrinsically different conception of history: a progressive and a passive one. The Catalan paragraph on the one hand presents history in a way that emphasises flow and change (cf. anonymous, »Amadeu Huriado atacant Miguel Maura «, El Be Negre, 2.53, 4). On the other hand, the Spanish version apathetically approves political gridlock, stating: »La historia es pasar el rato" - »History is just killing time« (cf. anonymous, »D. Amadeo Huriado adula a D. Miguel Maura «, El Be Negre, 2.53, 4).

Without repeating famous phrases by famous thinkers: the years between 1918 and 1939 were as thrilling as they were tense. Rival concepts and ideologies manifested themselves in multinational conferences and regional Catalonian policy. Differing views on history, however, were only one aspect of the controversy.

El Be Negre - The Black Sheep - belongs to a genre ranging between journalism and arts, politics and provocation: political satire published in particular satirical magazines. Either black and white or coloured, definitely sharp-tongued, their existence since the second half of the $19^{\text {th }}$ century was 
intrinsically linked to the freedom of press. ${ }^{1}$ However, forms of print media that combined entertainment with a witty criticism of their times prospered between 1919 and 1939 in Western Europe like never before - and never again thereafter. This article tries to analyse how the authors and caricaturists wittily defended their liberty, as well as liberty and peace on a social level. This, to the left-wing and liberal satirical media, meant defending the republican cause, whose politics enabled their publication. Taking a look at three interwar democracies - Germany's first (1919-1933), Spain's Second (1931-1936) and France's - late - Third Republic (1919-1940) - this article assesses the use of history as metaphor and symbol in each country's humorous media. To put it more precisely, this paper does not examine when satirical magazines hooked onto the differing concepts of history in order to describe their times, but asks: how did satirical magazines use actual examples of history for their argumentation?

As roughly outlined above, the publications that form the basis of this short comparative analysis all have one aspect in common: their political tone has been described as »left-wing «, »left-liberal« or »liberal«. It is easier, however, to tell what they were not: their reasoning was neither profascist nor pro-monarchal. ${ }^{2}$ Satirical magazines arguing in a rather rightwing political direction are only quoted if necessary to underline a development among pro-republican media.

The editorial offices of all these publications were situated in major cities, namely Berlin (Ulk), Munich (Simplicissimus), Paris (Le Canard Enchaîné, Le Merle Blanc), Barcelona (La Esquella de la Torratxa, El Be Negre) and Madrid (Buen Humor), thus intensively commenting on politics but also on social issues such as industrialisation, arts, fashion and female empowerment. The staff working for those magazines were rarely employed full-time. Hence, many freelance writers and artists published in several papers at the same time. ${ }^{3}$

1 An article this short cannot provide a history of the genre itself. For an overview of its development during the $19^{\text {th }}$ century in Germany cf. Koch 1991; for France: Ridiculosa, No. 18, Brest 2011; for Spain: Sánchez Aranda/Barrera del Barrio 1992.

2 The German Simplicissimus did not oppose its own »Gleichschaltung «, i.e. the replacement of Jewish editorial staff and an altering of the satirical tone, adapted to Nazi requirements.

3 Cf. the journal Ridiculosa No. 18, published in 2011 for short portraits on any French satiric newspaper, for instance the entries of Le Canard Enchaîné and Le Merle Blanc by Stéphanie Krapoth. The Spanish and German secondary literature 
This article attempts to compare satiric strategies on different levels of reference $^{4}$ : Firstly it deals with three interwar democracies. Secondly it looks at both an affirmative and a negative use of history as metaphor. In other words, it detects when history had either a legitimizing or a delegitimizing function. Finally, it takes into account visual and written sources alike because the weekly papers provided a mixture of caricatures, articles, columns and poems in a gradually changing composition.

Even though metaphorology has been focussing on the semantic and therefore word-based use of allegories, this study uses »metaphor « as an umbrella term to analyse the figurative aspects of both images and texts. ${ }^{5}$ That way it is possible to explore the journalistic concept of the media in which they were jointly published. And this, of course, leads to the integration of different theoretical approaches such as poetics and semiotics, metaphorology and iconography, history of arts and literature.

Furthermore, investigating humour confronts historians with a problem that cannot be solved following one orthodox methodological concept: how can we contextualise sources that are inherently ambivalent? Hence, deciphering satire in three different societies and four different languages requires a truly interdisciplinary approach which also engages the perspectives of political, cultural, intellectual and conceptual history.

is well advanced in years. Details on the respective Spanish media have been collected rather than thoroughly researched (i.e. López Ruiz 1995), the Catalan satiric press was mainly discussed by Lluis Sola i Dachs (Sola i Dachs 1978). For Germany cf. for instance an essay on the transformation of the German humour magazine during and after World War I (Simmons 1993).

4 Aiming at a contrasting comparison, this comparative study reflects both similarities and differences. In addition, it dares to be asymmetrical, i.e. not necessarily choosing the same amount of examples from every country. For the latest discussions on the methodological aspects of comparative historiography cf. Arndt et al. 2011.

5 Other young researchers have lately been advocating a similar approach, arguing on a much more theoretical level than this paper does. I would therefore like to recommend reading Rieke Schäfer and Imke Rajamani, whose instructive thoughts on the historicity of metaphors (Schäfer) and on how to extend the methods of conceptual history beyond word-based analysis to also visual or in her case audiovisual media (Rajamani) have been recently published in the $\gg$ Contributions to the History of Concepts« (cf. Schäfer 2012: 28-51; Rajamani 2012: 52-77). 


\section{Affirmative Use of History as Metaphor}

One of the most prominent authors of conceptual history - »Begriffsgeschichte« in German - was Reinhard Koselleck. He once stated that if he had not become a historian, he would have been a caricaturist (cf. Raphael 2006: 167). Although he drew remarkably funny caricatures of his colleagues and academic life, his professional research focussed on words, not on images. ${ }^{6}$ He opened historians' minds to the semantic change that words - or concepts - undergo in the course of time. A pivotal point of his work was reflecting on the French Revolution and the decades before and after 1789. The semantic field »revolution«, used both as term and metaphor, is, according to Koselleck, the topos par excellence for modern times, indicating uprising and political change as well as, in a broader sense, the structural change of society, science, culture and therefore comprising basically all areas of life (cf. Koselleck 2006: 240).

Koselleck's thesis can be applied to interwar satire: no matter whether German, French or Spanish, metaphors and symbols revolving around the topos »revolution" emerged constantly both in written and visual forms. Unsurprisingly, the French Revolution was the event of choice when satirical media referred to something historic in an affirmative way.

A telling example of this is a small caricature that can be found in $\mathrm{Le} \mathrm{Ca}$ nard Enchaîné's last January edition in 1924 showing some sort of penguin or snowman.

Figure 1: Anonymous: »Pour les elections«

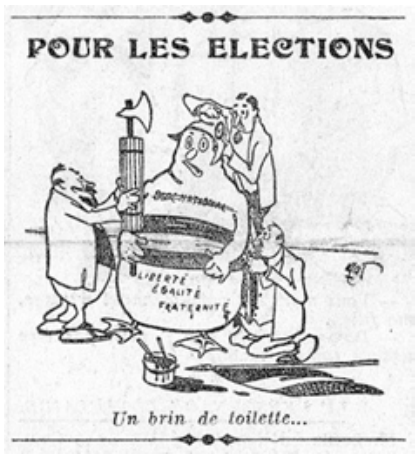

Source: Le Canard Enchaîné, 9.396, 1

6 For a selection of his caricatures cf. Koselleck 1983. 
Later that year, parliamentary elections took place in France. Whilst Le Merle Blanc strongly argued in favour of the left-wing alliance »Cartel des Gauches «, Le Canard Enchaîné was more impartial and also took a critical view at the possible governmental change in its satiric elements. No matter how the elections turn out, they argued, it would not mean profound change, but only "un brin de toilette « - an act of redressing and grooming the Republic. By labelling the snowman or penguin with key words such as »liberté, egalité, fraternité« and a Phrygian cap, the magazine warned that the actual core of democracy was fading away by degrading the Republic's symbols that had developed over the course of time to mere accessories.

In other cases, younger European Republics of the interwar period also used historic symbols as an allegory of democracy. Here again the Phrygian cap might serve as the most telling example. El Gorro Frigio, a vociferously anticlerical Spanish magazine published for a short period of time in 1931, was even directly named after the cap that had become a symbol of »Liberté « in revolutionary France. ${ }^{7}$ Spanish and German satire did not ridicule the Phrygian cap but kept on using it as an icon of freedom and liberty, emphasising the role of visual satire in Germany and Spain as a trademark for true Republicans and as a symbol of hope, especially during the initial stage of the respective Republics.

In November 1918 events began to move fast in Germany: marines neglected to set sail and fight a final, yet unpromising battle of the First World War. An air of revolution led Max von Baden to announce the Kaiser's abdication against his will and to transmit the power to social democrat Friedrich Ebert. On 9 November the Republic was proclaimed - twice, in fact, as Karl Liebknecht wanted to proclaim the so-called »Räterepublik«, a government based on councils according to the Soviet model. However, Philipp Scheidemann, a leading social democrat like Ebert, proclaimed a parliamentary Republic only two hours before Liebknecht. ${ }^{8}$ Scheidemann's concept prevailed. It was

7 Its characteristic form with top curling forward derives from a bull's testicles which the people of Phrygia, a state in Asia Minor from 8 BC on, used to wear as a headpiece. Later in Roman antiquity, emancipated slaves wore a cap with the same design to indicate their freedom. In the late Middle Ages it was again frequently used, before the French Revolution coined its meaning as a symbol of liberty (cf. Eberle 1966: 281-283).

8 For one of the most concise narrations of this transition from a monarchy at war to a parliamentary republic in English language cf. Fulbrook 2011: 21-27. 
the parliamentary model which Thomas Theodor Heine, founder and leading caricaturist of the German Simplicissimus, also favoured. Sympathising with what would become the Weimar Republic, he greeted it with a pompous and fairly humourless caricature.

Figure 2: Thomas Theodor Heine: "Hoffnung"

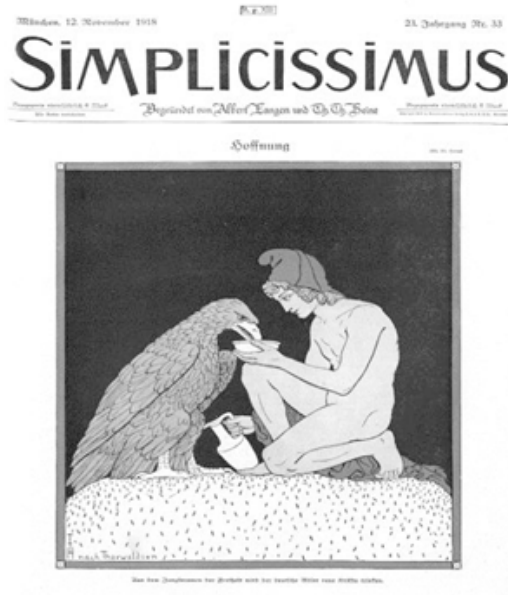

Source: Simplicissimus, 23.33, 1

The drawing on the front page of the edition published on 12 November 1918 shows a friendly looking eagle - the German heraldic animal. It drinks from a bowl handed to it by a kneeling young man. The man is barely dressed, resembling an antique statue and hence intensifying the connection between the young Republic and Greece as the homeland of democracy. The scene also makes references to Greek Mythology and the Fountain of Youth that was already mentioned as the source of all life by Herodotus and the Alexander Romance. In this caricature almost overloaded with symbols and allegories, it is the young man's Phrygian cap that is the most eye-catching element: Heine chose to paint it bright red, emphasizing the expectations that were placed on the Republic as the fundamental renewal and cure of Germany. ${ }^{9}$

9 This interpretation was, of course, even more emphasized by the caption which said: »Hoffnung. Aus dem Jungbrunnen der Freiheit wird der deutsche Adler neue 
Yet by October 1931 these hopes seemed to be literally dead, which a Simplicissimus cover page underlined.

Figure 3: Karl Arnold: »Der letzte Demokrat»

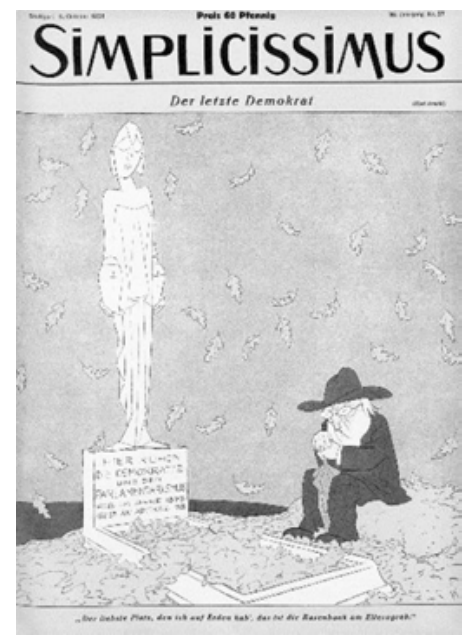

Source: Simplicissimus, 36.27, 1

Sitting next to the grave of »democracy« and »parliamentarianism«, »the last democrat« - as the headline said - mourns the loss. According to their gravestone they were killed by »Article 48 « of the Weimar constitution - the famous, or rather infamous, paragraph enabling the president to declare a State of Emergency which gave him authoritarian power. The gravestone shown in the caricature is a pale, thin stone figure of Lady Justice wearing a rather plain Phrygian cap: hope, along with the cap's brilliance, has faded.

The Second Republic in Spain, however, was also linked to great hopes for basic democratic values. Concerning the satiric media scene, it expressed the concrete expectation not to be censored any more - which might explain the high number of new, especially anticlerical releases. Freedom of speech and therefore freedom of press came into force from December 1931, when the new constitution was approved. By this time, it had already been almost a

Kräfte trinken.« (Hope. The German eagle shall gain new strength by drinking from the Fountain of Youth and Freedom). 
year since Primo de Rivera had given up on being the leader of a military dictatorship. The government of his successor, Damaso Berenguer, was no more successful and was ironically called »dictablanda « by contemporaries. ${ }^{10}$ Historians have stressed many reasons for the end of Bourbon monarchy and military government in spring 1931 . Yet the most immediate cause were the results of local elections in early April: republican parties won a landslide victory, especially in urbanised parts of the country, and hence one city after another pushed for political change and turned their backs on the old elites. Among all Spanish cities advocating democratic change, Barcelona has been rightly described as one of the most progressive. Furthermore, it had a tradition of publishing political and satirical magazines that can be traced back to the $18^{\text {th }}$ century (cf. Sánchez Aranda/Barrera del Barrio 1992: 299). In the early stage of the Second Republic, publications such as L'Esquella de la Torratxa or El Be Negre tried to deprive the old elites of any sort of credibility, which the following caricature points out exemplarily. Two weeks before the first parliamentary elections were to take place, the back page of L'Esquella de la Torratxa featured a shark and a deep-sea diver who was trying to massacre the predator with a sword.

10 The term is a wordplay as the female form of the adjective »duro«, Spanish for »hard «, is part of the Spanish word for dictatorship »dictadura «. »Blando« however is the antonym - soft - suggesting therefore that the Berenguer government might have been a dictatorship concerning its structure, but not necessarily concerning its brutality or assertiveness. The term has been adopted by political science to describe similar developments of the late Franco dictatorship or in South America. For a detailed and pleasantly condensed insight into the history of early $20^{\text {th }}$ century Spain cf. Casanova 2010: 7-150; Vincent 2007: 117-159. 
Figure 4: Del Río, untitled caricature

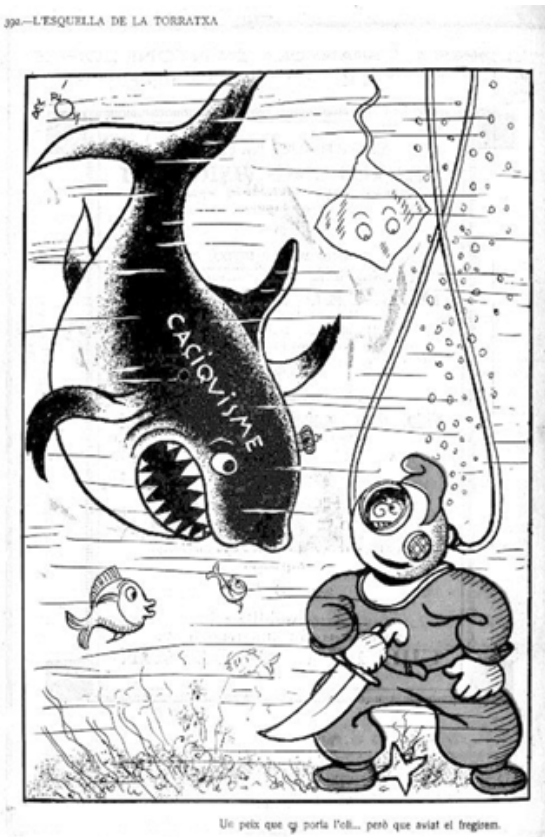

Source: L'Esquella de la Torratxa, 55.2710, 15

To avoid any confusion, the diver wore a Phrygian cap even above his helmet. The shark in contrast wore a little bourbon crown and was tagged with the word »caciquismo«, indicating only two out of the many trouble spots that Spain was confronted with at the time. Since the restoration period and the so called »Sexenio Revolucionario« 1868 to 1874 , the »caciques« played an important role in Spain as chiefs of the rather oligarchic and clientelistic rural areas. ${ }^{11}$ In the caricature, he is not only threatened by the sword but also by the legend saying:

»Un peix que es porta l'oli... pero que aviat el fregirem. ${ }^{12}$

Like the tagging of enemies, it was also quite common for contemporary satirical magazines in Spain to address their readers directly. This served the

11 The definition of the term »cacique« follows Bernecker 1990: 51.

$12 »$ A fish getting the oil... but we're going to fry it soon.» 
purpose of winning him or her to the Republican cause. Yet this practice changed after conservative parties won the 1934 elections, a development which will be looked at more closely later on. During the so-called »bienio negro «, the conservative and right-wing coalition from 1934 to early 1936, the legends in left-wing caricatures changed from the first person plural to imperatives. From then on, the satirical magazines were increasingly used as a platform to agitate and call the readers to direct action. This was also apparent in the caricature's aesthetics, reflecting the labour movement and incorporating elements of Soviet design. ${ }^{13}$ In other words: drawings that had been overtly infantile and friendly in their appearance with rather peaceful historic symbols referring to the French Revolution, became more explicit and inclement, no longer solely using the Phrygian cap, but also armed men as a symbol of the Republic. Each day, satire and propaganda became increasingly intermixed as the nation drifted towards civil war.

All examples cited so far have been taken from visual satire samples. Exploring historical metaphors in written satire is difficult in an article this short, as satirical texts took multiple forms in those magazines, ranging from headlines over poems to fragments and more extensive articles of very different styles and tones.

A general observation on the issue is therefore, that if European satiric media of the interwar period applied historical allegories to texts, they did so in a more subtle way than their graphic companions. In addition, metaphors of different categories - like animals, diseases or literary allusions - were intertwined. Nonetheless innumerable historical references can be found. Many, if not most of them, also pointed to the potential of the French Revolution.

In early 1924 for example, Le Canard Enchainé criticised the politics of the then French prime minister Raymond Poincaré by satirically quoting him: »Les taxes c'est moi «. ${ }^{14}$ The line was printed as a subtitle on the magazine's front page and was therefore highly visible to everyone, even to those who just passed a bookstall but did not necessarily buy a copy. By altering one of

13 For Stalinist Propaganda and poster art cf. for instance Czech/Doll 2007: 200-247.

The front page of the edition published on 14 February 1936 underlines this point:

L'Esquella de la Torratxa, 60.2954, 1.

14 Le Canard Enchaîné, No. 399, 20 February 1924, 1. 
the most famous quotes in history, Louis XIV's »L'état c'est moi«, the satirical magazine put Poincaré on a level with the Sun King. The headline referred to Poincaré gaining "pleins pouvoirs financiers « on 8 February 1924 (cf. Winock 2007: 644). Yet a prime minister holding the monopoly on public expenditure, however explicable by financial crisis following the Ruhr occupation, must have severely threatened the editors so committed to democracy. By ironically fearing the reestablishment of absolutism, Le Canard Enchainé altered its call for political change, for a government that would respect democratic values more than the »Bloc National« did at the time. No matter how legal Poincaré's manoeuvres might have been, Le Canard Enchaîné warned the French about him misusing the constitution and the possibilities it contained in order to concentrate his power. A historical metaphor - condensed, plain and in prominent layout position - seemed just the suitable means.

It is about time to also take a look at German magazines. One of the most prominent figures of German interwar journalism, the literary and satirical scene was Kurt Tucholsky. He published thousands of articles, reviews and poems in daily newspapers such as the Vossische Zeitung or illustrated magazines like the Berlin-based, satirical Ulk, the social democratic Wahre Jakob or the less political but rather entertaining $U h u$ to name but a few. ${ }^{15}$ In addition to that, he was the most productive contributor to the weekly magazine Die Weltbühne. The following examples are taken from this publication because they provide the most telling evidence for the point I am trying to make. Yet as it was neither an illustrated nor a solely satirical magazine like most of the media analysed in this study, a few extra words on this source seem indispensable at this point. The Weltbühne: Wochenschrift für Politik, Kunst \& Wirtschaft had an overtly serious tone and it was taken seriously. It sought to provide profound analysis of artistic, political and economic topics and it uncovered scandals that led to several trials. ${ }^{16}$ Even though the print

15 For more details cf. Tucholsky's catalogue raisonnée (Bonitz/Wirtz 1991).

16 The so called »Weltbühne-Prozess « in 1929 was certainly one of the most discussed trials of the interwar period in and outside Germany. The trial accused and sentenced chief editor Carl von Ossietzky of treason and espionage after having printed a critical report on secret air force activities (cf. Suhr 1997: 54-69). Furthermore, Le Canard Enchaîné kept showing that investigative journalism and satire do not contradict each other, uncovering for instance the Stavisky affair in 1934 (cf. Martin 2005: 155-158). 
run of around 15,000 copies per week was comparably low, reader circles all over the world guaranteed quite a wide reception. ${ }^{17}$ Not following any specific programme, the Weltbühne remained critical - especially in its political satire - of all parties. This hints at the most relevant of Weltbühne's characteristics for the purposes of this study: in addition to its serious content, the weekly magazine was a forum for contemporary satire. Satirical poems most of them signed with one of Tucholsky's noms de plume like Ignaz Wrobel or Theobald Tiger - and other rather funny but anonymously published elements were interspersed between longer articles in order to separate the different editorial sections. However, satirical components criticising events of the day increased in volume the longer the Weimar Republic endured, even though freedom of press was concurrently threatened by certain modifications of the law which concerned the Weltbühne in several ways. ${ }^{18}$

Historical allegories appeared infrequently in Tucholsky's work, but he did metaphorically refer to the French Revolution when emphasizing the lack of revolutionary quality in November 1918. In fact, he repeatedly pointed to this diagnosis, and in one of his ironic poems he stated that the »November-Revolution « was a true "German revolution « - well organized and bureaucratic but uninspired and gutless. He argued that the Germans were denying the guillotine not because they were an intrinsically peaceful folk but because putting it up was against the law - laws shaped by a government that revolutionary impulses would actually seek to overcome:

»Das war eine deutsche Revolution:

Eine mit Organisation, eine mit Stempeln und Kompetenzen beileibe nicht mit wilden Tänzen um Guillotinen Nee, über Ihnen aber auch! Das ist des Landes nicht der Brauch!

Denn >das Aufstellen solcher Maschinen ist allen Roten

17 The existence of these circles was regularly mentioned in the Weltbühne itself, where addresses of readers who organised the meetings were displayed. Reader's circles in Sao Paulo and Montevideo were mentioned, for instance, on the last page of the April $12^{\text {th }}$ edition (cf. Weltbühne, 28.15).

18 The editorial strategy behind this interspersed satire as well as the proportions of satirical and serious elements in the Weltbühne has not been examined and will be an integral part of my yet unfinished and unpublished dissertation. 
auf öffentlichen Plätzen bei Strafe verboten!

(gez.) Piesecke Kommissar. « ${ }^{19}$

Even though Tucholsky became especially famous for his satirical poetry, he also invented another format of textual satire which is worth being considered here: the so called $»$ Schnipsel $«$ - short, ironic notes bundled in a column. $^{20}$ Especially in the late Weimar Republic almost every edition of the Weltbühne published a number of them, but »Schnipsel«-like satire, i.e. short aphoristic sentences, can also be found in Spanish and French media, the more the magazines were threatened by censorship. In other words: »Schnipsel« become of interest when taking a look at the editorial level of satirical journalism and how it dealt with censorship, because if the respective authority found them unsuitable, these loose sentences could easily be removed from the layout.

Again, Tucholsky incessantly pointed to Germany missing a real revolution. One of these condensed comparisons has nowadays become a muchquoted aphorism. ${ }^{21}$ Yet its first publication dates back to the »Schnipsel«section of the Weltbühne. Tucholsky wrote (cf. Weltbühne 26.53, 32):

»Wegen ungünstiger Witterung fand die deutsche Revolution in der Musik statt.«"22

In this very last »Schnipsel « of the year 1930, Tucholsky chose a metaphor that combined conclusions from musical history and political history developments in music being catalysed by German composers such as Bach or, around 1800, Beethoven, set against the profound political and social transformations simultaneously emanating from the French Revolution, and finishing with the most down-to-earth German archetype: bad weather.

Up to this point, all cited examples used history as an affirmative reference. To swiftly review this strategy, it must be underlined that the historical metaphors used served as an identifying feature for something pure and true.

19 The poem was first published in 1920, it was here quoted after a re-edition (cf. Tucholsky 1985: 112).

20 The most suitable translation seems to be »snippet«.

21 It is, for instance, one of several literary quotes written on façades in Weimar city centre, erected to brighten up the city when it became European Capital of Culture in 1999.

$22 »$ Due to bad weather conditions, the German Revolution took place in music.« 
As a result, the phenomenon or person that was linked to it was meant to evoke positive associations, i.e. people wearing Phrygian caps being easily identifiable as republicans. Beyond identification, affirmative historical metaphors also intended to judge the present by a distinguished perception of the past. When referring to the French Revolution as the change par excellence, caricatures and satirical texts set the bar high for contemporary events and their appraisal.

\section{Negative Use of History as Metaphor}

This leads to the question of whether satirical media also used historical metaphors in a negative way. To provide a brief conclusion to this question, the answer is yes. Even though sources prove this strategy was altogether applied less frequently, it had interesting effects.

The German satirical press used negative historical metaphors more often than Spanish or French media. The first example is again taken from the Weimar Republic:

The Ulk used this strategy of referring to the past negatively when bringing up the issue of Germany's recent past - the Kaiserreich. This period from 1871 to 1914 had not only shaped Germany's recent past, but also the Weimar present and, eventually, also the country's future, something that became more than clear in the 1925 presidential elections. They were won by Paul von Hindenburg, 77 years old at the time. With him, the Germans voted for the geriatric incarnation of the Wilhelmine past, for one of the most ardent propagandists of the stab-in-the-back-legend and, as Robert Gerwarth and Anna von der Golz have so elegantly shown in their books on the Bismarck and Hindenburg myth, for a symbolic leader of anti-republican forces rather than a vital and capable politician whose aura was quite present in German society. ${ }^{23}$

23 »The mythological connection between Bismarck and his >successor Hindenburg was thus already established and the election campaigners of 1925 were well aware of its political appeal.« (Gerwarth 2005: 88).

$24 \gg$ In 1925, therefore, [Hindenburg's] myth did not have to be revived. It had been firmly established as a vital component and political weapon in the right-wing struggle against the Weimar >system $<$ and the Treaty of Versailles. The announcement of his candidacy for the presidency in April 1925 was thus the logi- 
Yet first things first: After the initial round of the presidential elections had ended in March 1925 without any of the many candidates reaching an absolute majority, the parties formed blocks and nominated only two candidates for a second round. The parties of the governing democratic Weimar coalition agreed upon Wilhelm Marx from the moderate and catholic »Zentrumspartei « as their candidate and his election seemed almost sure, until right wing forces sought and found a rival candidate of extreme popularity - Junker Field Marshal Hindenburg who had not even participated in the first round. The nomination of the war hero and committed protestant not only appealed to monarchist voters who identified him with a glorious German past, but also to non-Catholic moderate parties such as the BVP (Bayerische Volkspartei) that turned to him instead of Marx (cf. Kolb 2000: 81). Support from these groups decisively contributed to Hindenburg's victory on 26 April - a victory that many historians have pointed out as characteristic of how paradoxically Germany's first republic developed. ${ }^{24}$

Like any other left-wing press, the Ulk was not really alarmed by Hindenburg's candidature. In fact, the opposite was the case: it pretended to already know the result of the elections, despite the old warhorse's reappearance on the political stage. To them, Marx was the only possible successor to Ebert. By presenting him a priori as the winner, they renounced one of satire's most substantial qualities: subtlety. Hindenburg was considered to be too absurd to ridicule, and thus the danger for a Weimar Republic whose Head of State was identical to the >Victor of Tannenberg « was underestimated dramatically. In fact, both the Ulk and the Simplicissimus tried to combat German lack of democratic values looming in the enthusiasm that accompanied Hindenburg's candidature with the very same symbols that right-wing press and propaganda simultaneously used to push him: comparing his

cal outcome of a right-wing strategy rehearsed since 1919.« (von der Golz 2009: 83).

$24 »$ Hindenburg's election was symptomatic of wider trends. As far as the actual functioning of parliamentary democracy was concerned, all was far from well even before the onset of the recession. Under an electoral system of proportional representation, in which the relatively numerous parties held radically different opinions on a range of domestic and foreign affairs, it was extremely difficult to form any sort of stable coalition government with majority support in Parliament, even in the >good years «." (Fulbrook 2011: 39). 
comeback to the historic figure of Bismarck and to the foundation of the Kaiserreich in 1871.

Thus this paper takes a closer look at a conservative and monarchist satirical magazine before going into details on the Ulk and Simplicissimus: the Kladderadatsch, a magazine that underwent considerable political change in its long existence. It used to be a rather democratic, revolutionary publication when found in 1848, but stayed loyal to the Kaiserreich after the First World War. ${ }^{25}$ In 1925, the Kladderadatsch accompanied Hindenburg's candidature and subsequent victory with sustained applause.

Figure 5: Arthur Johnson: »Der Lotse besteigt das Schiff»

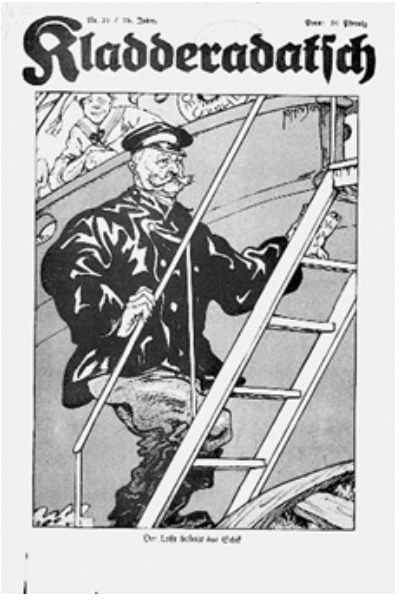

Source: Kladderadatsch, 78.19, 1

Concerning the use of history, Johnson's caricature involved two historical components: on the one hand, the drawing incorporated historic personalities and on the other hand it referred to the iconographic history of the satirical genre itself. That is to say the drawing was almost a copy of Sir John Tenniel's famous caricature »Dropping the pilot«, published in 1890 by the British satirical magazine Punch, shortly after Bismarck had been dismissed by Kaiser Wilhelm II.

25 Analysing the conservative Kladderadatsch would actually be worthy of new research. Meanwhile cf. Allen 1984; Heinrich-Jost (ed.) 1982; Koch 1991. 
Figure 6: John Tenniel: »Dropping the pilot»

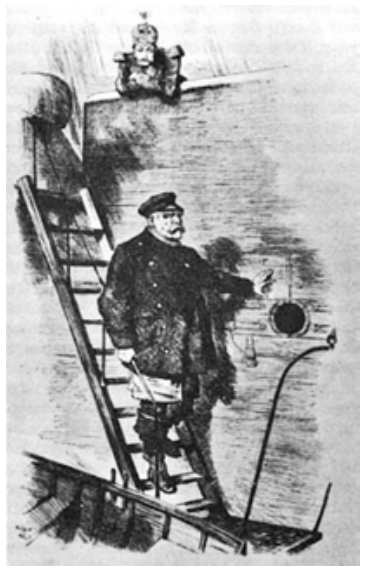

Source: Punch, 98.29, 32

In his engraving, Tenniel compared the German Reich to a ship losing its pilotage - a caricature that had gained enormous fame in Germany, where the translated title »Der Lotse geht von Bord « became almost idiomatic. Tenniel captured what historians have been analysing since Bismarck's dismissal: without him, the Kaiserreich seemed to have lost its compass and the failure of the premiers who came after Bismarck played a role in the gradual emergence of a Bismarck myth before, during and after the First World War. At any rate, the scene shown in the Kladderadatsch in 1925 suggests a reversion of history: Kaiser or not, a pilot was finally on board again - and wasn't a good steersman just the man to manoeuvre a ship through a dangerous current?

As mentioned above, the Ulk frequently tried to refer negatively to Bismarck and the Kaiserreich when countering the menace of Hindenburg's possible presidency. 
Figure 7: Willi Steinert: »Steuermann Tirpitz»

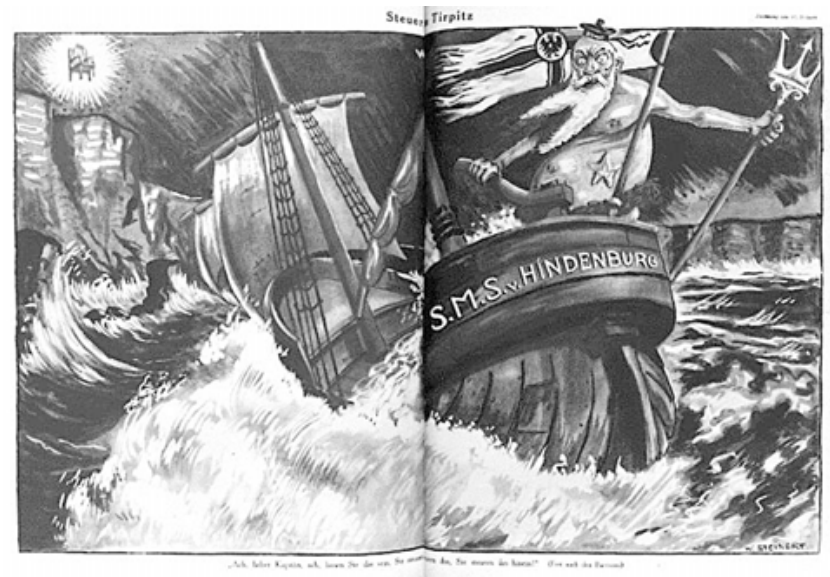

Source: Ulk, 54.17, 4-5

Here "your majesty Hindenburg « refers to the ship, as indicated by the title »Seine Majestät Hindenburg «. The ship, Hindenburg, is being steered by old general Tirpitz with his characteristic beard: it had indeed been his old comrade Tirpitz who travelled to Hindenburg's retirement home in Hannover and persuaded him to run for office (cf. Pyta 2007: 161-174). The whole scene - night, the cliffs of Helgoland and quite a rough sea - suggests the threat of capsizing. The opulent, two-page caricature is complimented by a little rhyme which pretended the Ulk even felt sorry for Hindenburg being wrecked by Tirpitz:

»Ach, lieber Kapitän, ach lassen Sie das sein, Sie steuern ihn, steuern ihn hinein! «

$26 » \mathrm{Oh}$, dear captain, just let it be, you're getting him into trouble.« 
The Simplicissimus also connected Bismarck and Hindenburg.

Figure 8: Thomas Theodor Heine: »Das Katastrophenjahr«

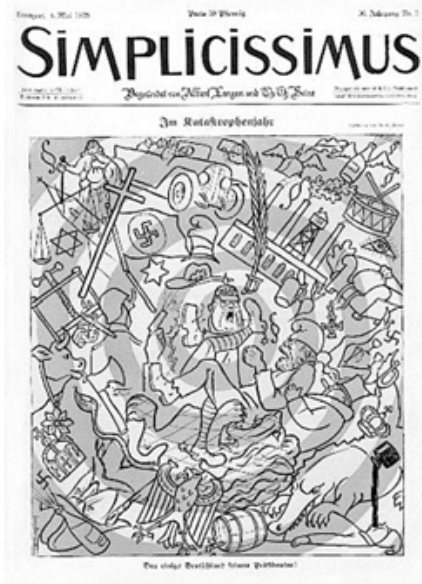

Source: Simplicissimus, 30.5, 1

The illustration suggests a swirl of chaos and violence if Hindenburg were to be elected. Yet the very centre of the caricature forms the most explicit symbol of Bismarck: a spiked helmet. In addition to that, the laconic line somehow invidiously commemorates the unification of Germany, when the Kaiserreich was proclaimed in Versailles 1871:

»Das einige Deutschland seinem Präsidenten. $\ll^{27}$

Both examples taken from Ulk and Simplicissimus point to one central aspect of why the negative use of a historical metaphor did not work out the way the authors would have liked it to: an analysis of the double use of historical allegories in the 1925 elections reveals that left-wing humour lacked positive symbols and catchwords in favour of democracy. Their strategy to vilify Hindenburg by comparing him to the Kaiserreich failed, as both the

27 »The unified Germany to its president.« 
Bismarck and Hindenburg myths were already deep-seated in German interwar society.

A similar example of how the lack of positive symbols in left-wing satire played into the hands of non-republican forces can be isolated for the Spanish case. However, as this did not involve historical metaphors but concerned the labelling of beasts as »cacique « or »falange «, as already mentioned above, I will try to only give a brief synthesis of the development. In 1933 the tags that used to distinguish between the enemies somehow fused into one word: »dretes « meaning »right-wing « in Catalan. This practice involuntarily reflected and emphasized a formation that was simultaneously taking place in Spanish politics: right-wing forces formed the CEDA (Confede-ración Española de Derechas Autónomas), an electoral alliance that actually won the majority in November 1933, successively calling off some of the reforms the previous government had at least tried to implement.

The history of French left-wing interwar satire does not know such a crux, yet negative references to history can indeed be found. The media also chose to focus their attention on a highly prominent figure: Napoleon Bonaparte. He served as the most telling example of an individual's insatiable thirst for power; one example leads back to the aforementioned governance of the »Cartel des Gauches «, or more precisely: to its end.

In July 1926 Le Canard Enchaîné compared André Tardieu to Napoleon, insinuating that the rather conservative politician strove for another office, no matter the cost. ${ }^{28}$

Only two weeks later the left-wing alliance broke down due to the ongoing financial crisis. ${ }^{29}$ To solve it, someone quite familiar was asked to form a new government: Raymond Poincaré, who had not only been Prime and Financial minister of the »Bloc National « but also one of the politicians who most ardently advocated for the »Union Sacrée« during the First World War

28 The article and comic depicting Tardieu's life not only compared him to Napoleon, but also to Mussolini, thus warning the readers of him as a possible dictator (cf. Épinal, »Tardieu-le-dictateur«, Le Canard Enchaîné, 11.523, 4).

29 Financial Minister Eduard Herriot had unavailingly tried to reform French tax politics in order to solve the country's financial problems. His plans failed because they ran against both the economy and the »Banque de France «. He resigned, yet his successors were also unable to overcome this opposition, meaning the end of the »Cartel des Gauches«by July 1926 (cf. Martens 2005: 382). 
- a political agreement in which all parties joined, thereby pausing political dispute for the length of the war. His new 1926 government was, however, named after both - »Union Nationale «. It united politicians from quite a broad political spectrum. And among them was the ambitious André Tardieu who became the new Minister of Transportation.

History, of all things, is past time. Yet what gives time having irrevocably passed its meaning is documentation and narration. The satiric potential of history thus lies in its truth-building process through narration, in its function as a link between past, present and future in order to help »human beings [to] live in the tense intersection of remembered past and expected future « (Rüsen 2005: 2).

This article illustrated how pro-republican interwar satire in Germany, France and Spain knew basically two sorts of satiric strategy: an affirmative and a negating use of history as an allegory to criticise the present and therefore somehow try to affect the future.

Satire mostly referred to the French Revolution as a synonym of profound yet positive change when arguing affirmatively. Nonetheless the magazines' satiric strategies differed gradually: in Spain's Second Republic the Phrygian cap served as an indication of democracy, i.e. as something indisputably pure, true and good. German satire however used the French Revolution as a metaphoric standard to compare the recent change from Kaiserreich to Weimar Republic. By doing so, readers were invited to realise that the events of November 1918 did not deserve to be called a revolution. For French satirical media, these apparently affirmative references were eventually more ambivalent: they extended their implication and employed them as warnings, indicating that it took more than symbols for a sound democracy.

When referring to history in a negative way, the satirical magazines examined in this article mainly chose historic figures or the recent past as their point of reference. The French had Napoleon Bonaparte as an example of man's unconditional drive to power. German interwar satire resurrected Bismarck when Hindenburg became presidential candidate in 1925 and thus provided an interesting case of how and why left-liberal satiric strategy did not work out in quite the way their authors would have liked it to. By trying to give a negative connotation to the same historic persons that right-wing press and propaganda simultaneously used to showcase Hindenburg, the satirical magazines involuntarily helped to spread the Bismarck and Hindenburg myth. Instead, they could have substantially countered the emerging historical master narrative with their own, positive counter-arguments. 
Furthermore, compared to allegories connected to »real « people of a recent, yet to be interpreted past, the antique, impersonal and symbolic references used to defend democracy were too abstract and ineffectual in the lead-up to 1933, 1936 or 1939.

\section{LITERATURE}

\section{Primary sources}

Simplicissimus (1876-1944), München.

<www.simplicissimus.info>.

Ulk. Illustriertes Wochenblatt für Humor und Satire (1872-1934), Berlin.

<http://digi.ub.uni-heidelberg.de/diglit/ulk> (only the years 1914 to 1930 are digitalised).

Die Weltbühne. Wochenschrift für Politik, Kunst, Wirtschaft (1918-1933), Berlin. Reprint (1978), Taunusstein: Athenäum Verlag.

L'Esquella de la Torratxa (1872-1939), Barcelona.

Digitalised by the Biblioteca Virtual de Prensa Histórica.

<http://prensahistorica mcu.es>.

El Be Negre (1931-1936), Barcelona. www.bvph.es

$<$ http://prensahistorica mcu.es>.

Le Canard Enchaîné (1915-today), Paris.

No digitalisations nor reprints. Completely archived at the Bibliothèque Nationale de France.

Tucholsky, Kurt (1985): Die zufällige Republik - Schriften zur Politik, Frankfurt/Main: Büchergilde Gutenberg.

\section{Secondary sources}

Allen, Ann T. (1984): Satire and Society in Wilhelmine Germany - »Kladderadatsch" and »Simplicissimus« 1890-1914, Lexington: University Press of Kentucky.

Agnes Arndt, Agnes et al. (eds.) (2011): Vergleichen, verflechten, verwirren. Europäische Geschichtsschreibung zwischen Theorie und Praxis, Göttingen: Vandenhoeck \& Ruprecht.

Bernecker, Walter L. (ed.) (1990): Spanien-Lexikon, München: Beck.

Bonitz, Antja/Thomas Wirtz (1991): Kurt Tucholsky, ein Verzeichnis seiner Schriften, 2: Beiträge in Periodica, Anthologien und Sammelwerken, Marbach: Deutsche Schillergesellschaft. 
Casanova, Julián (2010): The Spanish Republic and Civil War, Cambridge: Cambridge University Press.

Czech, Hans-Jörg/Nikola Doll (2007): Kunst und Propaganda im Streit der Nationen 1930-1945, Dresden: Sandstein.

Daniel, Ute (2006): »Reinhart Koselleck «. In: Lutz Raphael (ed.): Klassiker der Geschichtswissenschaft, München: Beck, 166-195.

Eberle, Josef (1966): Lateinische Nächte, Stuttgart: Deutsche Verlagsanstalt.

Fulbrook, Mary (2011): A History of Germany 1918-2008: The Divided Nation, Chichester: Wiley-Blackwell.

Gerwarth, Robert (2005): The Bismarck Myth, Weimar Germany and the Legacy of the Iron Chancellor, Oxford: Oxford University Press.

Heinrich-Jost, Ingrid (ed.) (1982): »Kladderadatsch«. Die Geschichte eines Berliner Witzblattes von 1848 bis ins Dritte Reich, Köln: Leske.

Koch, Ursula E. (1991): Der Teufel in Berlin. Von der Märzrevolution bis zu Bismarcks Entlassung, illustrierte politische Witzblätter einer Metropole 1848-1890, Köln: Leske.

Kolb, Eberhard (2000): Die Weimarer Republik, München: Oldenbourg.

Koselleck, Reinhard (1983): Vorbilder - Bilder, gezeichnet von Reinhard Koselleck. Bielefeld: Elbracht.

Koselleck, Reinhard (2006): Begriffsgeschichten, Frankfurt/Main: Suhrkamp.

Lopez Ruiz, José María (1995): La vida alegre, historia de las revistas humorísticas, festivas y satíricas publicadas en la villa y corte de Madrid, Madrid: Compañía Literaria.

Martens, Stefan (2005): »Vom Ersten Weltkrieg bis zum Ende des VichyRegimes«. In: Ernst Hinrichs (ed.): Kleine Geschichte Frankreichs, Bonn: Bundeszentrale für politische Bildung, 361-416.

Martin, Laurent (2005): »Le Canard Enchaîné«. Histoire d'un journal satirique (1916-2005), Paris: Nouveau Monde.

Pyta, Wolfram (2007): Hindenburg - Herrschaft zwischen Hohenzollern und Hitler, München: Pantheon.

Rajamani, Imka (2012): »Pictures, Emotions, Conceptual Change: Anger in Popular Hindi Cinema«. In: Contributions to the History of Concepts 7.2, New York: Berghahn Books, 52-77.

Rüsen, Jörn (2005): History - Narration, Orientation, Interpretation, New York: Berghahn Books.

Sánchez Aranda, José/Carlos Barrera del Barrio (1992): Historia del periodismo español: desde sus orígenes hasta 1975, Pamplona: Ediciones Universidad de Navarra. 
Schäfer, Rieke (2912): »Historicizing Strong Metaphors, A Challenge for Conceptual History«. In: Contributions to the History of Concepts 7.2, New York: Berghahn Books, 28-51.

Simmons, Sherwin (1993): »War, Revolution, and the Transformation of the German Humor Magazine, 1914-27«. In: Art Journal 52.1, New York: College Art Association of America.

Solà i Dachs, Lluís (1978): La premsa humorística, Barcelona: Bruguera.

Suhr, Elke (1997): »Zu den Hintergründen des >Weltbühnen<-Prozesses«. In: Marita Bruns (ed.): Allein mit dem Wort. Erich Mühsam, Carl von Ossietzky, Kurt Tucholsky. Schriftstellerprozesse in der Weimarer Republik, Lübeck: Schriften der Erich-Mühsam-Gesellschaft, 54-69.

Mary Vincent (2007), Spain 1833-2002, Oxford: Oxford University Press. von der Golz, Anna (2009), Hindenburg - Power, Myth, and the Rise of the Nazis, Oxford: Oxford University Press.

Various Authors (2011). In: Ridiculosa, No. 18, Brest: Equipe Interdisciplinaire de Recherche sur l'Image Satirique.

Winock, Michel (1997): Le siècle des intellectuels, Paris: Éditions du Seuil. 


\section{More than Resistance: Political Humour Under Stalin in the $1930 \mathrm{~s}^{1}$}

JONATHAN WATERLOW

When used as a historical source, the political humour of populations living under repressive regimes is almost always interpreted as evidence of some kind of popular »resistance « to state power, restrictions, or norms. This tendency finds reflection throughout different areas of scholarship: whether for Hitler's Germany (cf. Hillenbrand 1995), Franco's Spain (cf. Pi-Sunyer 1977), the post-slavery United States (cf. Levine 1977), or, according to anthropologist James C. Scott, theoretically in any human society (cf. Scott 1990). In each case, the equation is the same: humour equals resistance. Despite this generalisation, these works are undeniably rich and illuminating; »resistance « has often been a productive approach to social history, but all studies which take this approach tend to become fixated by the issue of defining »resistance«. Indeed, the issue of whether telling or laughing at politically contentious jokes constitutes »resistance « to a given regime will surely remain a matter of interpretative preference - of various definitional boundaries - rather than of objective fact. Does the joke-teller need consciously to consider their witticism an act of resistance? Does the failure of a joke to effect any measurable damage to the status quo render it somehow unworthy of that label, even if the state reacted violently against it?

In fact, we do not have to get caught within these intractable issues, for exchanges of humour can reveal much more to us about the nature of society, sociability, and contemporaries' cognitive processes without the need to place these all within the problematic framework of »resistance«. In the space available here, I will attempt briefly to sketch some rather different and, I suggest, more analytically productive approaches to the study of humour under a repressive regime which has severely restricted the possibility

1 The research project from which this piece is drawn was generously funded by the Arts and Humanities Research Council, UK. Thanks are also due to Jacques Schuhmacher and Milan Terlunen for their helpful feedback on drafts of this chapter, and also to David Priestland and Nicholas Stargardt for their role in supervising the thesis from which this analysis originates. 
of critical speech. In humour we can gain a sense of how citizens spoke to each other (rather than to Power) about their lived experiences, and how they thereby came to interpret and adapt to the circumstances in which they found themselves. Humour can both receive/accept and yet also criticise; it can belittle and hold at arm's length, yet stop short of outright rejection. It can therefore illuminate many dynamic and critical engagements with Soviet ideology and the lived realities of the 1930s and help us to understand some of the interpretive, coping and ultimately adaptive processes by which citizens who could effect little practical change in their lives, and did not take direct action against the state, were nevertheless constantly grappling with it.

The article is based on extensive archival research, utilising contemporary reports on »the mood of the people«, and on the criminal records of several hundred citizens arrested and sentenced for the crime of »antisoviet agitation « - here, this meant simply telling a joke which the regime found unacceptable. The significance of these sources is reinforced by published collections of anekdoty (jokes); while the archival sources allow us to learn with greater confidence where and when a particular joke was told, the voluminous anthologies demonstrate the longevity and wide dissemination of this humorous oral discourse. Two final points: the focus here is on what the content of popular humour can tell us; for this reason and due to space constrictions, I give little attention to the timing and location of these exchanges, nor to the people who told them (for more on these issues, cf. Waterlow 2012; 2013). Finally, although this article focuses on popular, political humour under pre-war Stalinism, it is hoped that these approaches might also aid the study of societies under other repressive regimes.

\section{BATTLES OVER SIGNIFICATION}

One of the most common elements of Soviet citizens' political humour was not simply to reject state propaganda or institutions, but to allow official discourse to highlight its own shortcomings. In a country awash with propaganda, citizens were very familiar with the regime's principal ideological slogans. Ubiquity led to mockery: a key genre of contemporary humour was the repetition of these official slogans in contexts which deflated and undermined their claims; given the disjuncture between optimistic slogans and the grim reality of 1930s life, the possibilities for doing this were abundant. For example, an anekdot which undercuts the standard refrain »Long live Soviet power! «: 
»Radek [an old Bolshevik, later purged] had his monthly allowance reduced from 30 to 15 rubles [as a punishment]. He responded by telegram: >Received 15 rubles Long live Soviet power! « (GARF 8131/31/64008/26)

Similarly, endless official calls for $»$ Vigilance « in propaganda were belittled by highlighting the irrelevance or mendacity of such calls given the abysmal material conditions and need for petty theft just to survive. Hence the boss of a Leningrad Metallurgical Plant responded to these demands by noting flippantly: »Yes, I've become more vigilant; I don't even sleep at night - I'm [busy] guarding my firewood!« (CGAIPD 25/5/48/48). Most common, it seems, was to repeat Stalin's famous 1935 declaration that »life has become better, comrades, life has become merrier «. Everyday experiences proved otherwise, and some people openly laughed when the slogan was repeated (GARF 8131/31/43804/13; 6264/7). Others recited it when faced with low quality produce: A.F. Firsikov noted witheringly that the tinned cod in his work canteen was so bad it had previously been used as pig food, adding later, »Cod again? Indeed it has got better, life has become merrier! « (GARF 8131/31/1247/10). Perhaps most common was the more circumspect sarcasm exemplified by a Leningrad factory worker: »Well, how merry « (CGAIPD 25/10/74/30).

Juxtaposition produced comedy, but to invoke these slogans was distinctly limited in its criticism. Official discourse was being made to mock itself, but, crucially, this was therefore criticism within regime ideology; not a criticism in relation to an alternative, external standard, but a demand that things should work as they were supposed to. Nevertheless, as contemporary theorist Mikhail Bachtin (who often critiqued the Stalinist regime between the lines of his work) argued of power in general, »the ruling class strives to impart a supraclass, eternal character to the ideological sign, to extinguish or drive inward the struggle between social value judgments which occurs in it, to make the sign uniaccentual« (Bakhtin 1973: 23). Repeating slogans in these inappropriate contexts was a clear contestation of the officiallyrendered meaning, breaking the semantic unity demanded by the Soviet state.

The countless official acronyms and contractions - signifiers for various government departments, shops, policies etc. - provided another rich source for contestation. For example, MTS (Machine-Tractor Station) was reinterpreted as »Mogila Tovarišča Stalina « (The Grave of Comrade Stalin), and the country's own initialisation, SSSR, was rendered »Smert' Stalina Spaset Rossiju« (Stalin's Death will Save Russia). So well-known did the latter 
meaning become, that it was used by the Nazis in 1941 on leaflets inviting Red Army soldiers to defect, complete with a tear-off voucher guaranteeing them safe passage (cf. Archipova/Mel'ničenko 2010: 342).

This practice was not confined to the most prominent official signifiers, however: in a state where all of life was theoretically political, popular contestations of meaning were ubiquitous. Many everyday objects could be imbued with a critical subtext - even cigarettes:

»A customer enters a shop and asks the shopkeeper for some cigarettes with a revolutionary name - >Something like, 'What we fought for (Za chto borolis')' keeper replies, , We don't have 'What we fought for', but we do have what we ended up with (Na chto naporolis')<, and hands the customer the brand 'Soviet'." (GARF 8131/31/7038: 78)

Similarly, S.N. Aktimirov, an accountant, made a dark quip that the design of »White Sea Canal« cigarette packets, featuring a map with the waterway's course highlighted in red, represented the $»$ blood shed by the builders of the canal«(GARF 8131/31/8782: 5). Thousands had died in its construction.

Given the widespread propensity to reclaim various kinds of signifiers or symbols, it is reasonable to assume that there were far more examples of Soviet citizens thus imbuing everyday items with a critical multivalency that often escaped detection by the authorities and hence remain invisible to us now. Bachtin proposed that every ideological sign »has two faces, like Janus «, with each »face « or signified contradicting the other; the »face« which one perceives depends upon one's ideological outlook (cf. Bakhtin 1973: 23). For 1930s Soviet citizens, there clearly existed a substantial collection of secondary, unofficial »faces « upon which they might focus. I do not mean to suggest that citizens were constantly contesting the »meaning « of every name, product or slogan, but, rather, that such a contestation was always possible.

M.A. Krongauz provides us with a useful model for this. He argued that, at least in the later period of »developed socialism «, there existed two »languages « in the USSR: the ritualistic »Soviet-Russian« and »Russian« itself. He described this as a »diglossia«: two languages which Soviet citizens could employ, with varying priority given to each one at any given moment (cf. Krongauz 1994: 236-237). Although Krongauz's use of »Russian« ignores the many other languages in the Soviet Union, his point is well made that an official, ritualistic language existed alongside an alternative, popular one, and that in practice the borders between those languages were porous. 
Consequently, for Soviet citizens the world was not filtered through a monolithic, official discourse in which all words, concepts or even everyday objects were defined by the state alone. From the most grandiose slogans, via the omnipresent acronyms and contractions of newspeak, right down to the lowly pack of cigarettes, ordinary Soviet citizens took these signifiers and created and shared their own alternative interpretations of them in parallel to the official language. It is too much to name this a fully-fledged language, but this could at least be considered an alternative idiom. Citizens did not, therefore, only »speak Bolshevik « (Kotkin 1997), but could also speak a vernacular replete with additional signifieds for countless signifiers held in common between the two idioms.

It is too great a generalisation to suggest that all Soviet citizens were speaking one specific unofficial idiom in the 1930s, especially if we remember that in order to use such a vernacular safely, it would have to be spoken only in relatively small groups secured by bonds of trust and, therefore, could not be subject to any broad standardisation. (For more on »trust groups « cf. Waterlow 2013). Therefore, we must not reduce the range of possible meanings to just one official and one contradictory alternative: Soviet citizens' worldview was neither homogenised, nor positioned in direct, absolute contradiction of official ideology and culture. Instead, the examples examined here suggest a broad popular attempt to reconcile the incongruities between official signifiers and the realities which ordinary people encountered in life; this was an inherently critical act, at the heart of which lay not a simple rejection of ideological claims, but a strong desire that these should live up to their promise. Hence the people did fight for the promises of the Bolsheviks, but the current »Soviet« reality fails to deliver on those pledges; hence blame is limited to individuals, rather than focused on the system at large (Stalin's deathsaves Russia).

To adapt Bachtin's proposition, we might better say that it was ordinary Soviet citizens who were, or could be, Janus-faced: it was they who could look at the world around them from two different viewpoints, viewpoints which were, crucially, intimately connected. Furthermore, this proposition recognises individuals' subjectivity and agency in the process: the signifier did not turn a second face to the observer, but the observer had to look at it a different way. 


\section{THE »GREAT TERROR«}

Humour could thus be used to engage with the regime's symbols and slogans, but how did it relate to a particularly disruptive, destructive event like the mass arrests of the so-called »Great Terror«, which swept across the country in $1937 / 38$ ?

In response to the arbitrariness of arrest, a joke circulated in which a schoolteacher asks a pupil, »Who wrote [the famous Puškin poem] Evgenij Onegin?«, to which the instinctively cautious child replies, »Not me!«. Enraged at this foolishness, the teacher calls in the boy's parents, but they also stubbornly affirm that he did not write Evgenij Onegin. Confused and angry, the teacher runs into an acquaintance who works for the NKVD who agrees to investigate the family's obtuse behaviour. Sometime later, the NKVD agent proudly reports back that he's closed the case: »The bastards finally confessed that they'd all written Evgenij Onegin together!« (based on GARF, 8131/31/10568: 8; Brandenberger 2009: 116-118; HIP 64/A/6: 6768).

A sardonic exchange between two workers in the Krasnaja znamja factory, Leningrad, played on the same theme: »Where's the map of the world? « one asked, searching for said item. His colleague replied, »The map's been arrested. The C[entral] C[committee] sent it to prison. « (CGAIPD 24/2v/ 2664/203). At this point, in 1937, when things or even people vanish, the assumption might as well be that they have been arrested. Similarly, one Govorov, a photographer, related the following joke to a friend in 1938: »Who makes up the USSR? - Many enemies and just one friend of the people.« (GARF 8131/31/19123/26). Clearly, Stalin is the only unequivocal »friend of the people«, while anyone else was in danger of being considered an enemy.

These jokes directly highlight the unpredictability but also the absurdity of the Terror's arbitrary mass arrests; as certainties were undermined and nothing could be relied upon to remain in place, for some people the only thing to do was to laugh about it. If people could not avoid these state actions practically, they could at least do so mentally; in humour they found one way by which to cope with, rather than attempting to deny the encroachments of the state on their everyday lives. Joking here operated as a kind of »gallows humour «; that is, a humour which laughs in the face of frightening yet intractable circumstances. Because in humour there is no expectation that things must make strict, logical sense, shifting frightening and uncontrollable events into this genre helps to defuse the fear or unease 
they might cause - they do not come to make sense, but the pressure for them to do so is removed, or is at least ameliorated. This gallows humour dealt with the grim events not by explaining them, but by explaining them away; the incomprehensible was mocked precisely for its incomprehensibility. This did not change the circumstances in which citizens found themselves, of course, but it did, at least to some extent, change how they might feel about them - a theme developed in the following section.

\section{A Sense of Agency}

A sense of agency is certainly a constituent part of popular resistance, however broadly defined, but the former does not always imply the latter. The arrested joke-tellers in my sample do not seem to have been self-consciously or actively antisoviet: almost none had criminal records and any additional charges of conspiracy made against them were, given the absence of any evidence in their criminal records, clearly fictitious (cf. Waterlow 2012: ch. 1). And, insofar as we can access the motives of joke-tellers who were arrested in these years, they were, under questioning, often quite shocked that their jokes were considered »antisoviet agitation«. This seems plausible, because over a quarter of the cases examined involved arrests more than a year after a joke was told (what was safe at the time of telling was only retrospectively deemed unacceptable), and the incidence of arrest for joketelling clearly fluctuated over the course of the decade, clustering around particular »flashpoints « when the state decided, arbitrarily, to crack down on critical speech.

There is not space here to go into detail, but the picture which emerges is that citizens who told jokes could not reasonably have expected that their witticisms would get them in nearly as much trouble as they often did (up to 25 years in the Gulag, although most often 10). Although political joketelling was always a transgressive act, it is untenable to posit a broader scheme of self-conscious opposition (let alone a conspiracy) as underlying this practice.

If the agency felt by Soviet joke-tellers was not that of a staunch regime opponent demonstratively attacking the system, then what was their motivation, and what did they gain from telling these jokes? The gallows humour effect offers part, but not the whole answer. If the joke-tellers were not motivated solely by political opposition, then we may learn more from their jokes which were not straightforwardly or explicitly political in the sense of 
criticising regime policies or figures. Indeed, much contemporary humour actually took the form of a brief, throwaway flippancy. For example, A.I. Šilo, an X-Ray technician at a hospital on the Turkestan-Siberian railway, was shopping with friends for placards and portraits to celebrate the new Stalin Constitution. When his friend asked the shopkeeper, »Do you have anything about the new Constitution?«, Silo butted in with the crude rhyme, »Do you have anything about prostitution? « (GARF 8131/31/82045/9). In another shop, a doctor by the name of G.F. Narožnyj sarcastically enquired, »Are you going to get anything good in, or will it all be Soviet trash (drjan')? « (GARF 8131/31/88415/13). And, in a dramatic final example, Nečaj, a shop head at a radio factory and award-winning shockworker (an especially productive labourer), entered a room in which a brigade meeting was in process and loudly quipped, echoing the language of propaganda: »I've come to drink the workers' blood! «. Although some tried to defend his outburst as a joke, all were later convinced to reinterpret his words as $»$ the act of a class-alien person « (GARF 5451/42/262/63).

These very basic jokes broke for a moment the »fourth wall « of the Soviet drama scripted by the state; indulging in behaviour inappropriate to the »role « of Soviet citizen allowed the joke-teller (and potentially their audience) a momentary release from the constraints of »acceptable « behaviour constraints they felt acutely, for citizens were expected to act as though they lived in a world enormously different to the one which they daily saw before them. These were simplistic, performative transgressions in public social contexts which lack any significant reflection or critical insight - they were naughty rather than knowing. As such, they can be directly related to children's enjoyment of writing rude words or drawing vulgar pictures, even when they do not necessarily know what they mean.

To take just one example, we can see this in the spread of a particularly forbidden symbol. During break-time, fourth-graders at a school in Solombal'skij rajon, Archangel'sk, drew swastikas in chalk on their hands and stamped them onto their classmates' backs (RGASPI M1/23/1265/50). ${ }^{2}$ The same game was reported amongst older students at the Tomsk Transport Institute (RGASPI M1/23/1106/129). A rather enterprising student in Kyiv oblast', Liza Zabrodskaja, along with her friends, even carved a swastika into a potato and proceeded to stamp swastikas all over their school (HDA SBU 16/30/113/90). The thrill of drawing this particular contraband symbol

2 The report identifies one child and one instance in particular, but when questioned the schoolchildren claimed this was not a new game. 
was not limited to children, either: accountant and former Red Army solider, P.N. Dyšlis, doodled two small swastikas on the front of a newspaper - on an article written by Stalin - while waiting for a haircut at the barber's. A fellow customer discovered these and reported him. Yet despite eventually admitting that he drew the swastikas, Dyšlis apparently could not explain to the NKVD why he had done so. In fact, it is quite possible that he did not have a particular aim in mind (HDA SBU 6/35430FP).

As with the children, a full or conscious understanding of the symbol and the act of drawing it was not really important: the very thrill of creating an illicit image - of having the power to create one - can be intensely attractive, giving a psychological high of some potency in an otherwise prescriptive life - be that the life of a child in general, or of an adult in the Soviet Union. Indeed, all acts of humorous transgression, whether ostentatiously or quietly performed, represented more than just the simple pleasure of breaking taboos. At the core of these jokes lay a search for a sense of personal agency within a state which had assumed the right to speak for every citizen.

This sense of agency was the mental gratification gained from using critical humour, yet that agency was rather ephemeral. As the gallows humour effect illustrates, to joke about immutable circumstances was not to change them, but only to change how one might feel about them. This was not resignation, then, but an active attempt to grapple with the difficulties of powerlessness; the transient feeling of agency could ease the pain of acquiescing to difficult realities. This was both a conscious and unconscious process of adjustment: Soviet citizens could consciously reassure themselves that they were not fools unable to see the deficiencies of life in the 1930s by making scathing and humorous comments about it, yet this humour was simultaneously, if unconsciously, reconciling them to those deficiencies. After the joke was over, the self-reassurance performed, one simply had to get back to work. This remained, nevertheless, a distinctly ambivalent acquiescence.

\section{SAVOIR-FAIRE}

Turning to some extent from the issue of why joke-tellers might risk sharing potentially dangerous humour, another productive way to analyse these contemporary jokes is to examine their didactic function. This was a decade in which all of life seemed to be in unpredictable flux, but humour continued to provide Soviet citizens with a method of communication through which to share insight and guidance, thereby helping one another (re)gain a sense of 
how their world functioned. Indeed, jokes are rather like parables or proverbs, being concise and often ironic tales or apt phrases which serve to convey information about the world and how to live in it successfully. These fragments of »wisdom « worked as a »sense-making device«. This is a description which Andrea Mayr has applied to prison argot: an »insider « idiom which grows to enable the powerless to share their own, unofficial understandings of the world they cohabit alongside, yet apart from, official discourse (cf. Mayr 2004: 154 [quoting D. Wieder]).

Many of the previously cited jokes are good examples of the proverbial function of some jokes in action: a general »truth « about a given subject is summed up concisely, pointedly and memorably. These were officially contraband truisms which crystallised popular interpretations of the Soviet regime. There were, however, more complex variations within this proverblike genre; these moved beyond mere statement of »fact«, and offered specific advice on how one should act to avoid trouble and to get ahead within the system. Once again, these were often formed by twisting or inverting memorable slogans so that they really did, ironically, convey a picture of life during the period.

The famous maxim, »He who does not work, shall not eat«, was altered to highlight the need for theft in order to survive in the 1930s: »He who does not steal, shall not eat «(RGASPI 671/1/257: 27). Another saying went, »The quieter you are, the further you go « (or, indeed, »the further you go, the quieter you are «) (GARF 8131/31/95714: 10; 3316/16a/446: 162; HIP 61/A 15: 13). Other jokes warned people not to trust particular Soviet leaders: one advised people to »read [Leningrad Party boss] Kirov's name backwards«, making the word $»$ vorik «, or »little thief« (RGASPI M1/23/1102/168). Another leader's name - Vorošilov - was open to similar abuse, as demonstrated by a vandalised portrait discovered with all but the first three letters of his name (»vor «: thief) crossed out (CDAHOU 1/20/6642/27).

A further example cautioned against trusting the Soviet press, playing on the literal meanings of Pravda (truth) and Izvestija (news): »There is no truth in Pravda and no news in Izvestija «. This last example, and variations of it, most clearly straddled the boundary between something noted bitterly by contemporaries, and an amusing anekdot. Some citizens merely stated it as bald fact that there was often no »truth « in Pravda (RGASPI M1/23/1184: 98; NA 389/15: 79), while others recited it as a joke (HIP 5/A/1: 44; 95/A/7: 29; 451/A/22: 42) neatly illustrating how anekdoty could often shade into practical life advice. 
In this way, official signifiers were being transformed from lies into genuine descriptors of the social realities facing the Soviet citizen of the 1930s; because they were »guides « to a building site, of course, there was an implicit anticipation within these popular hints and tips that they would at some point become redundant. For the time being, however, a significant body of lifelessons and satirical observations were in this way shared within trust groups; in their combination, this was creating a fugitive body of savoir-faire - a shared knowledge of not only fallacies within regime ideology, but also of strategies, tips or guides as to how one could still navigate and live through the difficulties of contemporary life. This savoir-faire represented a normalising purpose, of learning the »rules of the game « and thereby coming to accept those rules as simply how the world worked - hence the transmission of those »rules « in the didactic forms of proverb-style jokes (and, although I will not examine these here, Aesopian-style fables). To adopt Bourdieu's terminology, the exchange of humour was thus creating a »habitus«:

»The habitus is necessity internalized and converted into a disposition that generates meaningful practices and meaning-giving perceptions«. (Bourdieu 2010: 166)

Soviet citizens used humour to create this interpretive lens - this habitus which was not only transforming inescapable, unwelcome realities into something which could be understood, but also something which progressively appeared to be »normal «. This does not mean that citizens felt satisfied or happy about these new »norms «, only that they were adapting to, rather than standing firmly against, them.

\section{Crosshatching}

It would be impossible to argue that a stable habitus or sense of »normality « was established during this decade, and humour continued to bear witness to the population's struggles to address and adapt to the ever-changing present right up to the outbreak of war. Therefore, in conclusion, I offer not an attempt to crystallise a particular status quo or to discover when a particular popular »worldview « was achieved, but instead to propose a metaphor with which to better conceptualise the processes of understanding and adaptation which continued throughout the second decade of Soviet power.

As we have seen, the new Soviet ideology and its attendant policies were constantly confronted by alternative popular viewpoints, and the two often 
seemed utterly incompatible. How was it possible for these two perspectives to co-exist? In fact, this was not a co-existence, nor even truly an opposition. This was not Orwell's infamous »doublethink«, in which two conflicting opinions are held hermetically sealed from each other in a single person's mind, thereby preserving two »realities « in a paradox of sorts. Nor did citizens choose from »a variety of idioms « (Davies 1997: 16) to suit particular situations without these also interacting with each other and being affected by official ideology. This study of humour demonstrates that no such quarantine-like isolation of official (state) and unofficial (personal) »reality « existed in the 1930s; citizens constantly engaged with and criticised the disparities, attempting to find some way to reconcile or at least to understand how the two could exist concurrently. Rather than speak of paradoxes and contradictions, therefore, we should attempt to understand the interconnectedness of these elements - of propaganda and lived everyday experience for the Soviet citizen was, of course, constantly encountering both.

Soviet citizens perceived and understood the world of the 1930s and their lives within it in a complex and hybridised manner. I propose that we can best conceptualise this through the image of crosshatching. ${ }^{3}$ Crosshatching is a drawing technique in which two sets of parallel lines intersect, thereby creating a grid of variable density. Although a simple technique, by varying the proximity, the angle of intersection, and thickness of each set of lines, a remarkable level of detail and texture can be achieved, adding depth, shading, and solidity to an image. If we take one set of those parallel lines to represent the various elements of official regime ideology, then the other set, intersecting the first at an angle, was made up of the numerous sources of critical popular opinion which we have been examining.

This model therefore incorporates numerous moments of intersection or engagement, allowing for significant variability in the particular elements of official and unofficial discourses and values which came into contact on any given occasion. It helps us to understand the interconnectedness of these "contradictions « and to appreciate the ways in which they were actively involved with each other, rather than assuming them to forever bypass or to cancel each other out. And while we cannot map out all or even most of these moments of engagement between official and popular discourses - not least because each person would have their own particular view of reality we can yet describe the general nature of those engagements in order to

3 The idea for this conceptualisation was inspired by a novel which uses the metaphor rather differently (cf. Miéville 2009). 
facilitate a more useful approach to the examination of particular instances. Soviet citizens did not meet Soviet power and its nebulous official ideology head-on; they instead approached many of its propositions, policies and personalities from oblique angles, neither denying nor accepting them in their totality, and instead blending them with their own perspectives and beliefs. That is to say, they attempted to blend their own, unofficial understandings and values with the regime's in such a way as to create meaningful patterns, both consciously and unconsciously. These were constantly occurring yet always fleeting relations; they were repeat encounters between official and unofficial discourses which together formed patterns in their crosshatching. In so doing, perspectives of significant nuance, density and depth could develop.

The Janus-faced Soviet citizen could thus see and identify the official discourse, but only truly »understood « it - its meaning in real life - when it was crosshatched with their own or a trust group's values and experiences. It was in this way that slogans and official tropes were made to mock themselves: by placing or articulating them in real-life scenarios, their gravitas was made to look absurd by the added context of, or image created by the intersection with, the second set of hatching. More broadly, official regime values were also used to throw older beliefs into a new light: some believers cited the Stalin Constitution to defend their right to worship, for example, thereby blending the regime's discourse with their own beliefs (cf. Davies 1997: 78). Similarly, others tried to argue that if all repossessed church buildings now belonged to »the people «, then »the people « could decide to reopen them if they so wished (cf. Husband 1998: 87-88). However, the opposite effect was also possible: citizens might accept particular Soviet policies by blending them with preexisting religious teachings - for example, by criticising or persecuting kulaks (allegedly rich peasants) because the gospels also proclaimed »Woe to you, the rich « (Davies 1997: 78). In a further, striking example, a Lutheran pastor attempted to crosshatch official and religious values in a 1936 sermon which he concluded with the words, »We must become Stachanovites of our belief and religion«! (Davies 1997: 78).

The most significant examples of crosshatching are the instances of savoir-faire examined above. Each embodies the »discovery « of patterns in the crosshatching, in which particular unofficial »rules of the game « were established and were then disseminated between citizens in a proverb-like format, in order to help them navigate through these unstable times. Initially created by citizens interweaving their own experiences with particular elements of 
official ideology, certain patterns were thus fixed in "proverbs « and hence spread as increasingly de facto depictions of (popular) reality. The image of crosshatching reveals the way in which the »wishing it would work « factor and popular attempts to reconcile or path-find functioned in practice: this was a mixture of many different elements, official and unofficial, constantly interacting with each other and, in their sum, made by contemporaries to form patterns, motivated at root by the need and desire to make sense of the world in which they lived.

\section{Conclusion}

Studying political humour can reveal far more about a society living under a repressive regime - especially one undergoing intense change - than merely evidence of a will to »resist « the state and its various norms. Indeed, an examination of contemporaries' humour in the 1930s Soviet Union suggests that, while a subversive practice, joke-telling was in many ways concerned with the resolutely quotidian rather than the grand sweep of politics, and that it was shared by people who neither acted like nor appeared to consider themselves opponents of the system. This is not to say that they did not challenge the regime's power, but rather that they did so in specific, indirect ways: by reappropriating both official language and adding different significance to other elements of a life over which the state claimed interpretational hegemony, citizens could regain for themselves a potent sense of agency and thereby alleviate the fear and powerlessness which might otherwise overwhelm them. As the model of crosshatching helps to explain, however, these critical engagements should not be seen in terms of oppositions; the interactions between official and unofficial values and discourses were, in their complex confluence, for many citizens ultimately serving to normalise, and enabling adaptations to, immutable circumstances. This was, at most, an ambivalent acquiescence, but it was also an increasingly stable habitus. 


\section{LITERATURE}

\section{Archival References}

Galuzevyj deržavnyj archiv služby bezpeky Ukrainy (HDA SBU): Sectoral State Archive of the Security Service of Ukraine (former KGB archive).

Gosudarstvennyj archiv Rossijskoj Federacii (GARF): State Archive of the Russian Federation.

Narodnyj archiv (NA): The People's Archive. (Reference is to the micro-

filmed portion of the archive, under the title Voice of the People Under Soviet Rule).

Rossijskii gosudarstvennyj archiv social'no-političeskoj istorii (RGASPI): Russian State Archive of Socio-Political History.

Central'nyj deržavnyj archiv gromads'kych ob"ednan' Ukrainy (CDAHOU):

Central State Archive of Public Organisations of Ukraine.

Central'nyj gosudarstvennyj archiv istoriko-politicheskich dokumentov Sankt-Peterburga (CGAIPD): Central State Archive of Historico-Political Documents, St Petersburg.

The Harvard Interview Project on the Soviet Social System (HIP).

\section{Printed Sources}

Archipova, Aleksandra/Mel'ničenko, Michail (2010): Anekdoty o Staline: Teksty, kommentarii, issledovanija, Moscow: OGI.

Bakhtin, M.M. (1973): Marxism and the Philosophy of Language, trans. Ladislav Matejka \& I.R. Titunik, New York/London: Harvard University Press.

Bourdieu, Pierre (2010): Distinction: A Social Critique of the Judgement of Taste, trans. Richard Nice, London: Routledge.

Brandenberger, David (2009): Political Humor under Stalin: An Anthology of Unofficial Jokes and Anecdotes, Bloomington: Slavica.

Davies, Sarah (1997): Popular Opinion in Stalin's Russia: Terror, Propaganda and Dissent, 1934-1941, Cambridge: Cambridge University Press. Hillenbrand, F.K.M. (1995): Underground Humour in Nazi Germany, 19331945, London: Routledge.

Husband, William B. (1998): »Soviet Atheism and Russian Orthodox Strategies of Resistance, 1917-1932«. In: Journal of Modern History 70.1, 74-107.

Kotkin, Stephen (1997): Magnetic Mountain: Stalinism as a Civilization, Berkeley: University of California Press. 
Krongauz, M.A. (1994): »Bessilie jazyka v epochu zrelogo socializma«. In: Znak: Sbornik statej po lingvistike, semiotike i poètike pamjati A.N. Žurinskogo, Moscow: Russkij učebnyi centr.

Levine, Lawrence W. (1977): Black Culture and Black Consciousness: AfroAmerican Folk Thought from Slavery to Freedom, New York: Oxford University Press.

Mayr, Andrea (2004): Prison Discourse: Language as a Means of Control and Resistance, Houndmills: Palgrave MacMillan.

Miéville, China (2009): The City and the City, London: Pan.

Pi-Sunyer, Oriol (1977): »Political Humor in a Dictatorial State: the Case of Spain«. In: Ethnohistory 24.2, 179-90.

Waterlow, Jonathan (2012): Popular Humour in Stalin's 1930s: A Study of Popular Opinion and Adaptation, DPhil Thesis: University of Oxford.

Waterlow, Jonathan (2013): »Intimating Trust: Popular Humour in Stalin's 1930s«. In: Cultural and Social History 10.2, 211-229. 


\title{
»Then We Will Fight in the Shade«
}

\author{
Sparta, Comedy and Coming to Terms \\ with Fearsome Otherness
}

\section{SABRINA FEICKERT}

The Greek stand at Thermopylae in $480 \mathrm{BCE}$ is one of the most famous battles in history. At the >Hot Gates`, a small, vastly outnumbered Greek contingent led by the Spartan king Leonidas and his 300-man bodyguard stood their ground against King Xerxes' Persian army which outnumbered them hugely. ${ }^{1}$ The Greek historiographer Herodotus, the only contemporary source for the events of the 2 nd Persian War, relates an anecdote about Spartan courage in his Histories $^{2}$ :

»[...] bravest of all was declared the Spartan Dienekes. [...] he was told [...] that the

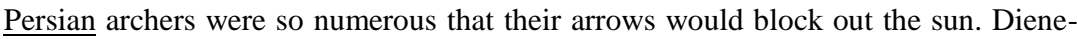
kes, however, undaunted by this prospect, remarked with a laugh, >Good. Then we will fight in the shade`.« (Herodotus, Histories, 7.226.1-2)

The Spartans did fight and, after three days of heroic efforts, were cut down to the last man. Crucially, however, their sacrifice delayed Xerxes long enough for the allied Greek forces to be able to retreat and regroup. The Persian army marched on, but was soon defeated by the Greeks on land and

1 I do not intend to discuss the historical accuracy of 300 or the political intentions of its producer. For a detailed analysis of the battle at Thermopylae cf. Cartledge 2007.

2 Herodotus' anecdote is also one of the most famous examples of the Spartan laconic wit, Laconia being the polis territory that surrounded the city of Sparta. In Spartan education, a lot of weight was put on the training of oral expression. According to Plutarch (Lyc. 19.1), Spartan boys learned »to express themselves in a style sharp but mixed with grace and profound in its brevity « and Aristotle relates that »from childhood they learn to speak briefly, and also to mock and be mocked in a suitable fashion «. Even Plato mentioned the Spartan aptitude at repartee in his Protagoras, explaining that even if the Spartans might usually make a poor show in a conversation, they would hit home out of nowhere with a short, compressed remark as deadly as a shot (Protagoras, 342e). 
at sea in three decisive battles: Salamis, Plataea and Mycale. But it was the Spartan stand at Thermopylae - not any of these battles - which would become the symbol of the successful fight for freedom and a subject for representation in art and more recently in film and television.

In 2007, Zack Snyder's Hollywood motion picture 300, which is based on the eponymous graphic novel by Frank Miller, ${ }^{3}$ conquered cinemas around the world. The film recreates the historical events of the Second Persian War, glorifying Spartan masculinity, martial prowess and their pursuit of kalòs thánatos - a >beautiful death - in battle. ${ }^{4}$ The message of Snyder's film is uncompromising: the Spartan way of life was war. Their ideal of the perfect warrior society, immaculate in body and mind, provided the foundation for every decision, every law, and every action.

The reactions to 300 were divided: many viewers loved it for the sheer force of its elaborate battle scenes and spectacular cinematography; others were shocked by its brutality or interpreted it as a propaganda movie promoting the clash between East and West and the ongoing conflict in Afghanistan, part of the wider War on Terror. A substantial number of voices also expressed strong reservations about a potentially fascist aesthetic underlying its visual language and message of >nly the strongest survive however, yet another kind of response can be found in the plethora of parodies and caricatures that sprang up almost overnight.

The first major parody was an episode of the iconic animated sitcom South Park by Tray Parker. »D-Yikes!«, which first aired on 11 April 2007, negotiates sexual identity against the backdrop of Snyder's motion picture. After having outed herself ${ }^{5}$ as gay in front of the class, transsexual teacher Ms. Garrison leads the regulars of the lesbian bar »Les Bos« in a stand against the Persian club-owner Xerxes, who was attempting to take over the bar and turn it into a »Club Persh Dance Club «. An epic battle ensues, at the end of which Xerxes admits to being a woman and engages in a passionate affair with Ms. Garrison. The episode culminates in the couple engaging in

3 Frank Miller not only provided the template, but was also directly involved in the filming of 300 as consultant and executive producer.

4 The beautiful death is a concept featuring strongly in the writings of Spartan poets like Tyrtaeus. In his words, it was »a fine thing for a brave man to die when he has fallen among the front ranks, while fighting for the homeland « (Tyrt. fr. 10.1-2).

5 I chose to use female pronouns for Ms. Garrison and Xerxes, as the subsequent scenes are played out in a lesbian bar and the characters are presenting themselves as female. 
an act of steamy lesbian sex with Ms. Garrison moaning »Oh yeah! Scissor me Xerxes! « and Xerxes deciding to forego her desire for conquest and to keep »Les Bos« a lesbian haven. »D-Yikes! « also parodies what was rapidly becoming the trademark quote from 300: when Persian emissaries show up at the bar they are taken aback by lesbian culture, proclaiming it »crazy«. Mirroring Leonidas' (Gerard Butler) cry of »Madness? This is Sparta!« before kicking the Persian envoy into a pit, Ms. Garrison screams »No, this isn’t crazy. This is >Les Bos $\iota$ ! before kicking the head-envoy hard between the legs.

Shortly after Comedy Central had aired »D-Yikes!«, another parody, Meet the Spartans, appeared in cinemas, poking fun at the warlike imagery and heroic postures of Snyder's film. Even though it received horrendous reviews, it grossed over $\$ 84$ million and became an international success. Although the humour featured in this »epic comedy « is both crude and shallow, Meet the Spartans boils its critique of 300 down to the bare bones: the Spartans are characterized as effeminate braggarts, hardly able to hide their homosexual preferences but also slightly ill-at-ease with them.

In addition to these two widely-known examples, there is also an abundance of web pages dedicated to poking fun at 300 and its depiction of the heroic battle, many of them based on Leonidas' iconic »This is Sparta!«. This paper approaches 300 against the backdrop of these comic representations which have turned it into the object of ridicule. I will argue that the negotiation of monolithic gender norms and rigid hetero-normativity and the theme of the abandonment of the individual self in favour of the collective good are being mocked in particular. In conclusion I will then explain how in the case of 300, humour and laughter act as catharsis to a range of conflicting emotions between fascination and repulsion as well as to contemporary ideas of existential anxiety.

\section{THE VISUAL LANGUAGE OF $\mathbf{3 0 0}$}

The moviemaking technique of 300 blends stylized graphics and live-action elements to achieve the maximum impact of overwhelming speed and immediacy (cf. Thompson 2007: 6-7). The Spartan disposition towards violence keeps the audience on edge. The frequent slow-motions and close-ups do not allow the viewer to be distracted from the shocking details of blood and gore; the almost naked bodies of the Spartan warriors demonstrate the constant exposure of the human body to injury and death. The artfully cap- 
tured play of muscles and the billowing of the Spartans' red war cloaks play a vital part in the visual choreography, as they transfer the fighters' tension and exertion to the bodies and minds of the audience. In 300, the Spartan ideal of a >beautiful death is omnipresent and dominates the screen.

It is an archaic, highly emotional and irrational ideal that openly contradicts our contemporary Western discourse with its tenor of an enlightened rationality and fluid concepts of gender, identity and individuality. Late $20^{\text {th }}$ and $21^{\text {st }}$ century cinema tends to draw on either disillusionment or irony to deal with the irrational and contradictory, particularly if it comes in the guise of experiences of war, brutality and militant masculinity. For example, in the films of Quentin Tarantino, who is regarded as a figurehead of ultraviolent cinema, audacity and searing irony are pivotal elements of the cinematography. Gory sequences of ruthless violence pass over into quick-witted, over-the-top dialogues between characters who are often slightly weird and preposterous but also highly individualistic. A similar effect is apparent in films like the Die Hard series, where John McLane's (Bruce Willis) catchphrase of »Yippee-ki-yay, motherfucker « and deadpan remarks have become just as iconic as exploding cars and action-packed gunfights.

In 300, however, the rhetoric of war and abandonment of the individual self comes across as both existential and free of irony and thus completely incompatible with contemporary discourse on violence and postmodern concepts of identity. While their Persian foes, in particular the elite force of the Immortals, are depicted as a faceless mass, ${ }^{6}$ the Spartans themselves are also endowed with only minimal individual traits. With no indicators of social rank or age, they are garbed in nothing but a blood red war cloak, speedo-style leather shorts, war belts and helmets hiding their features in battle scenes, while their waxed and chiseled bodies give them the appearance of cloned athletes. Battling beasts and animalistic Immortals, the Spartans' humanity and vulnerable mortality is communicated via their exposed bodies, which during these days of incredible exertion are sustained by the defiance of death and their indomitable will. On the battlefield, the Spartan existence climaxes in the abandonment of the individual self and its absorption into the immaculate perfection of the warrior collective. It is Leonidas himself who gets to the heart of this when he explains to the hunch-backed

6 The dehumanization of the Persian other is another motif running through film, recurring most strongly in the characterization of the Persian army which includes the allegedly soulless Immortals, whose disfigured faces are hidden by distorted silver masks, and numerous man-monstrosity-hybrids. 
outcast and eventual traitor Ephialtes (Andrew Tiernan) how the Spartan phalanx works: »We fight as a single, impenetrable unit. That is the source of our strength «. Although the Spartans' laconic witticisms - many of which can be traced back to Herodotus - seemingly bear a close resemblance to those of Die Hard's John McLane, they do not provide irony or comic relief but only serve to heighten the spectator's awe in the face of Spartan fearlessness and defiance of death.

Throughout the film, the violent mood remains an experience of otherness and foreignness which most strongly appeals to the emotional and subconscious levels. ${ }^{7}$ Intellectual discourse does little to support the audience of a film like 300 in accessing this. To the postmodern perspective, the historic events at Thermopylae act as a foil onto which instances of contemporary discourse can be projected in order to negotiate them in an apparently neutral setting. However, 300 does not invite introspection or an exterior viewpoint, as it completely foregoes irony or disillusionment. By sticking to the illustrative conventions of a graphic novel and enhancing these through cinematic techniques like slow-motions and close-ups, the film actively avoids any narrative structure that goes beyond rudimentary cinematic necessity.

Instead, 300 is composed of an array of battle scenes and duels within the battle, where the Spartans are caught in a Moebius strip of violence, without hope of relief. In this way, 300 tries to evade the grasp of interpretation by pretending that there is no real narrative threat, that only the moment matters, a moment in which body and mind are limited to the ultimate experience of near-death and existential struggle. Slow-motion sequences elongate brief moments such as a spear being aimed at an enemy, hitting his chest, penetrating his body, before being ripped out again trailed by a fountain of blood. Or the scene of Leonidas delivering a crippling blow with his shield, sending a Persian flying, of the Spartan king slowly regaining his focus before taking a few purposeful strides, raising his arm and, in a final cathartic fall to one knee, delivering the death blow. Parodies of 300 happily ridicule this narrative deficit by arbitrarily rewinding scenes or repeating them again and again to varying outcomes. The absurdity of both the faceless

7 For the film director and screenwriter Sam Peckinpah, an early icon of violent cinema, the experience of immediate transcendence and raw energy could only take place in a space removed from prosaic commonplace routine. It was only in confrontation with »the madness of ecstatic violence «, that a moment of utter »self-liberation that culminates in the forgetfulness of self « could be experienced (Murray 2004: 24). 
masses of the Persian army and the clone-like quality of the Spartan warriors are mocked when they are shown as products of a blue-screen trick in Meet the Spartans, for example. In »D-Yikes! «, the producers of South Park employed random slow motion distorting both actions and sound effects to imitate Snyder's trademark cinematography. The aestheticized violence of 300 is reduced to absurdity when the battle sequence described above is recreated in slow-motion in Meet the Spartans, initially copying each of Leonidas' moves, only to have him stabbing a Persian through the legs of another Spartan, barely missing his crotch. Leonidas then does a dive roll, pulls a wet towel from a random kettle and uses it to knock out an Immortal, before moving on to twist another Persian's nipples and to give a >wedgie< to a third one.

\section{Aestheticization OF VIOLENCE}

With many viewers, 300 strikes a chord that has nothing to do with analyzing its meta-narrative or discussing the justification of war and violence. What the film makes the audience experience, instead, is existential angst and the aesthetics of violence. Graphic representations of violence and death in battle are staged as the central aesthetic theme, corresponding to the hermeneutic logic established in the pit scene. ${ }^{8}$ As a result, it is the cinematography itself which renders distance impossible and creates a space in which the audience is confronted with and exposed to their emotions, while simultaneously denying the mind space for rational analysis. The highly aestheticized and abstract portrayal of violence provides a distance to the horrors of the battlefield, to death, injury and pain. It focuses on the art of war as a sublime entity and depicts warriors as artists and exalted beings, associating them with the sphere of godlike heroes and setting them apart from the reality of common men. In numerous aspects, 300 also brings to mind the works of the German nationalist philosopher and writer Ernst Jünger ${ }^{9}$, who created a veritable poetics of violence. His celebration of the beauty of war, of selfsacrifice and heroic death overrules all laws of logic, reason and humanity

8 The pit scene is discussed in detail below.

9 Both in Fire and Blood (Feuer und Blut, 1925) and Storm of Steel (In Stahlgewittern, 1920), graphic accounts of his experiences on the Western Front during World War I, Jünger glorifies war and violence in battle as an intense and mystical experience elevating the individual above their everyday existence. 
(cf. Wertheimer 1986: 320-322). Both in Jünger's writings and Snyder's film, the experience of war and violence takes place on an emotional, irrational and existential level which combines fear with excitement and attempts to exclude critical analysis. Even though the notion of violence as an aesthetic concept is a subject of controversy in contemporary discourse, it still holds an obscure fascination as it appeals to the unconscious, where Freud located both the origin of humour and of our hidden desires. This may be why >beautiful violences is still tolerated - and even appreciated - in the realm of art, where rational analysis may be abandoned. As Adorno and Horkheimer established in their Dialectic of Enlightenment (cf. Adorno/Horkheimer 1947), the mind resorts to myth as a foundation for comprehension, since modern discourse has failed to incorporate the foreign and irrational (cf. Emig 2001: 190). In this sense, the recourse to the historic battle at Thermopylae as the topic of a movie paves the way for the recourse to pre-enlightened explanatory strategies. In the domain of art, hyperviolence is usually awarded a space where the human body may be turned into the object of abuse on a symbolic level, where it invites critical debate or illustrates social wrongs and injustices. Yet when it is employed merely for the sake of its allure or on behalf of an aesthetic maxim which foregoes all sympathy with the victims of abuse and all analysis of those who perform it, hyper-violence is shifted from a representational level to a merely presentational one. Such examples of »pitiless art «, which render »the dead of concern only when either violating some existing prohibition or offering themselves up as images of torture «, show no recognition of their transgressions and do not accept what ethical concerns are at risk (cf. Virilio 2003: 5, 7-9). In 300, violence is not negotiated but elevated to the level of a superior aesthetic concept and philosophy represented in the Spartans' martial prowess, their readiness and ability to take lives - both those of their enemies and their own.

The historic setting creates distance and allows the staging of topics and perspectives not deemed otherwise appropriate. It is much easier to come to terms with the mentally disturbing effects of a film if we are able to attribute them to a distant and somewhat obscure past. That way, we are able to approve of ruthlessness and brutality while continuing to claim intellectual superiority. The setting in classical Sparta renders the experience of violence remote and places it in an age of myth and legend. Here, people live by rules which do not have to adhere to either formal jurisdiction or the principles of reason and enlightenment. However, the underlying message of 300 is that reason can be rightfully abandoned in times of war or when a society finds 
itself at a crossroads. Here, Snyder's film goes a long way to make it as easy as possible for the audience to identify with Leonidas and his men, piling one instance of Persian savagery and decadence on top of another. Xerxes' barbarity justifies all of the Spartans' violence and brutality, even when that means that they are shown erecting a wall cemented with the bodies of slaughtered Persians. However, the audience does not only connect with the Spartans because they fall victim to Persian cruelty and greed for power, but also because recent history has seen events which openly invite comparison. In the era of War on Terror, the motif of a clash between East and West, of a fight for freedom and heroic imagery and rhetoric very similar to that of Snyder's film have become a daily reality. In his rally at the dawn of battle, Leonidas declares that: »A new age has come, an age of freedom. And all will know that 300 Spartans gave their last breath to defend it $[\ldots] \ll$. Not only does this contradict historical events, it also brings to mind the American obsession with the rhetoric of freedom in the aftermath of 9/11, and, in particular, George Bush's addresses to the American people with their excessive use of the terms >freedom $<$ and $>$ liberty $<.{ }^{10}$ The U.S. opposition to tyranny in countries like Saudi Arabia or Pakistan, for example, is described as one of the »the greatest achievements in the history of freedom«, secured by »the dangerous and necessary work of fighting our enemies «. Bush goes on to declare that some Americans »have shown their devotion to our country in deaths that honored their whole lives - and we will always honor their names and their sacrifice $\ll .{ }^{11}$

The similarity between Bush's and Leonidas' choice of words is clear and needs no further comment. Whether or not these similarities were intended is less important than the extent to which they were perceived as such by the public. The box-office appeal of 300 proves that the film did strike a chord with many people and the nature of the parodies and witticisms di-

10 In his second inaugural address on January 20th 2005, for instance, Bush managed to use the word > freedom< 27 times and the word >liberty< 15 times within 21 minutes. Cf. »The Rhetoric of Freedom«, editorial in the Washington Post on 21 January 21 2005, Page A16 (<http://www.washingtonpost.com/wp-dyn/articles/A 25249-2005Jan20 html >). Accessed 12 February 2013.

11 A complete transcript can be found in the Selected Speeches of President George W. Bush 2001-2008, published in the White House archives (<http://georgewbushwhitehouse.archives.gov/infocus/bushrecord/documents/Selected_Speeches_George _W_Bush.pdf >). Accessed 12 February 2013. 
rected its way shows how narratives of violence and self-sacrifice on the battlefield create significant unease and discomfort when they are too obvious a reminder of the events of daily life. This can best be illustrated by the spoofs of two major battle scenes in Meet the Spartans. Here, the first clash between the armies is parodied as a dance battle between the Spartan host and the Immortals. Leonidas, who is pictured wearing a beanie-style hat, finishes his performance with a spectacular move and taunts the Persians in slang: »You got served!«. The Spartans then proceed to dance the Persian forces off the cliffs in a grotesque imitation of Zack Snyder's Spartans driving men and beasts out to sea, their broken bodies silhouetted against the golden horizon. And while in 300 the decisive encounter between Spartans and Persians culminates in the death of Leonidas and all his men under a shower of arrows, Meet the Spartans exploits the scene to make a mockery of the superior Persian military force. When Xerxes fails to beat Leonidas in a Grand Theft Auto video game challenge, he gets into a sports car which transforms itself into a giant robot, finally forcing Leonidas to admit that »He is a god-king « before Xerxes accidentally cuts off the power when he trips over his extension cord and crushes all surviving Spartans underneath him.

\section{GENDER AND HETERO-NORMATIVITY}

In the context of an all-encompassing experience of war, Leonidas and his Spartans symbolize a male norm that celebrates values like courage, aggression, and loyalty. The warrior's self-sacrifice on the battlefield is transformed into the ultimate expression of the pursuit of freedom and the concept of an archaic hegemonic masculinity. The characterization and depiction of Xerxes is in stark contrast to the image of the Spartan heteronormativity. In 300 he is portrayed as an androgynous, heavily pierced giant, clad only in a few pieces of golden cloth and jewelry, his superhuman height and deep voice at odds with his painted face. The Persian king's decadent and ambiguous sexuality is intentionally installed as a polar opposite to the austere masculinity of Leonidas and his men. While Xerxes' sexual identity carries strong hints of transgenderism, references to homoeroticism among the Spartans are either avoided or contrasted with explicit heterosexual experiences, for instance between Leonidas and his wife (cf. Es 2011: 19-21). When, during his conversation with the Persian emissaries, Leonidas condescendingly describes the Athenians as »boy-lovers«, he challenges both their 
readiness for battle and their masculinity. Ironically, the scene also constitutes one of the crudest deviations from what is known about the society of classical Sparta, which incorporated a ritualized cultural form of paiderastia into their educational system (cf. Cartledge 2007: 25). Even though 300 celebrates the aesthetic value of the male body, this takes place on an asexual and highly symbolic level. The Spartans' identical chiseled nudity is a symbol of their righteousness and readiness to sacrifice their lives for the common good, whereas the obscene gold-clad nudity of Xerxes and the monstrous bodies of his minions symbolize their effeminate and degenerate weakness, foreshadowing their eventual demise.

Interestingly, it is not the strictly hetero-normative and militant masculinity of the Spartans, but the hedonistic Persian environment with its hints at queer culture and transgenderism which more closely resembles contemporary standards. However, as 300 depicts it, traditional norms and rigid categories are crucial in times of danger and turmoil to provide security and ensure that all effort can go into the fight for survival instead of into the negotiation of individual identity. Thus the homogeneous collective of the Spartan kósmos is given preference over the multicultural decadence of the Persians.

Therefore, it is hardly surprising that mockery of the Spartan heteronormative masculinity remains a recurring motive in many jokes and parodies. In the South Park episode $\gg D-Y i k e s ! \ll$, the epic struggle for freedom and against tyranny is turned into a gender-bender pun, emphasizing the benefits of queer culture. In Meet the Spartans, Leonidas (Sean Maguire) and his men are accustomed to greeting a woman with a high-five and a man with a deep French kiss. Xerxes (Ken Davitian), whose androgynous sexual identity is a major theme in 300 , is depicted either as a woman in drag or as the negative stereotype of an oriental male: small and fat, with extensive body hair, a beard and heavy eyebrows, sporting a heavily gilded cell phone. His efforts to make Leonidas bow before him take the form of bazar haggling: »I bow for no man!« - »Take a knee? « - NNo!« - »Curtsey? «$»$ Enough!«, and when the Spartan king refuses to compromise, Xerxes eventually tricks him into bowing by pointing out that Leonidas' sandal is untied and needs fixing. 


\section{RE-NEGOtIATION OF REASON}

One of the film's pivotal scenes unfolds when a Persian envoy (Peter Mensah) and his retinue arrive in Sparta to negotiate an agreement with Xerxes. The alternative to such a surrender is alluded to and symbolized by the skulls and crowns of defeated kings carried by the Persians. Seemingly unfazed, however, King Leonidas explains to the Persian emissaries how the Spartans were perfectly willing to embrace death and destruction rather than bow to the Persian god-king. Once again, Herodotus provides the source for the incident which acted as the model for the subsequent scene: when the Persians sent envoys to the Spartans demanding a gift of earth and water, the traditional symbol of surrender, the Spartans threw them into a deep well, suggesting »Dig it out for yourselves! (Herodotus, Histories, 7.133.1).

Following Frank Miller's lead, Snyder turned Herodotus' anecdote into a major turning point determining the fate both of Leonidas' 300 men and the whole of Greece. After the Persian emissaries have arrived at Sparta, their leader is shown in deep conversation with Leonidas while striding through the city streets, Queen Gorgo (Lena Headey) and several Persian and Spartan warriors in tow. The Persian paints a lucid picture of Xerxes' superior military forces and godlike power, pointing out how it would be suicide to refuse submission and attempt to stand against him instead:

»If you value your lives over your complete annihilation, listen carefully, Leonidas. Xerxes conquers and controls everything he rests his eyes upon. [...] All the GodKing Xerxes requires is this: a simple offering of earth and water, a token of Sparta's submission to the will of Xerxes.«

Leonidas' reaction is delivered in a both provocative and mock-ironic tone, ignoring the interjection of his counselor Theron (Dominic West) to remain conciliatory:

"Submission? Now, that's a bit of a problem. See, rumour has it the Athenians have already turned you down. And if those philosophers and boy-lovers have found that kind of nerve $-[\ldots]$ And, of course, Spartans have their reputation to consider.«

Not deigning to acknowledge the challenge, the Persian emissary merely repeats his ultimatum and reminds Leonidas to choose his next words carefully, as »they may be your last as king «. 
Now a soft wind sets in, Leonidas' face is caught in close up, his eyes lingering on the beauty of the Spartan landscape, on a Spartan woman and her daughter and a group of young Spartan boys, all waiting with baited breath for their king to decide their fate. Finally, Leonidas' eyes turn towards Queen Gorgo's proud and assertive features, before turning back to the head emissary standing on the verge of a giant, brick-built pit. In a final moment of stillness, the king's voice whispers the words »earth and water « before audibly drawing his sword, aiming it at the Persian's throat. Eyes wide in disbelief, the emissary can find only one explanation for Leonidas' reaction: »Madman. You're a madman! «. Leonidas' answer is as laconic as Herodotus' account: indicating the pit, he quips: »Earth and water. You'll find plenty of both down there «. Shocked, the Persian appeals to reason: »No man, Persian or Greek, no man threatens a messenger!«. When, in cold fury, Leonidas counters that the Persians insulted his queen and threatened his people, all that is left for the emissary is a final, desperate cry: »This is blasphemy! This is madness! «. With the background music foreshadowing the lull before the storm, the king turns his gaze towards the queen once more; her face caught in a close-up, the ultimate decision is left to Gorgo. Only when she sets her features and nods assent, is Leonidas ready to burn all bridges: »Madness? This is Sparta!«. With a single mighty kick, he hurls the Persian emissary into the pit, re-sheathes his sword and, while the rest of the Persians are sent to their doom, strides back to his queen.

Leonidas' iconic »This is Sparta!« has not only turned into an internationally known catchphrase, but has also become the movie's most frequently parodied quote. In Meet the Spartans, Leonidas not only drenches the Persian emissary in spittle when he gives the iconic shout, he also sends another Persian after him with a flying dropkick, while the corrupt councilman Traitoro (Diedrich Bader) urges him to »Stop kicking people into the Pit of Death, really! «. After all the Persians have been dealt with, Leonidas proceeds to kick an over-the-top Britney Spears, Kevin Federline, and finally the entire jury of American Idol into the pit. The internet was brimming over with spoofs and caricatures of people yelling »This is Sparta!« in the most unlikely contexts or of Leonidas' cut-out screaming face transplanted onto different bodies, for example in a photomontage of Who Wants To Be A Millionaire. 
Figure 1 \& 2: Internet spoofs of the »Pit of Death « scene and the »This is Sparta! « catch phrase ${ }^{12}$
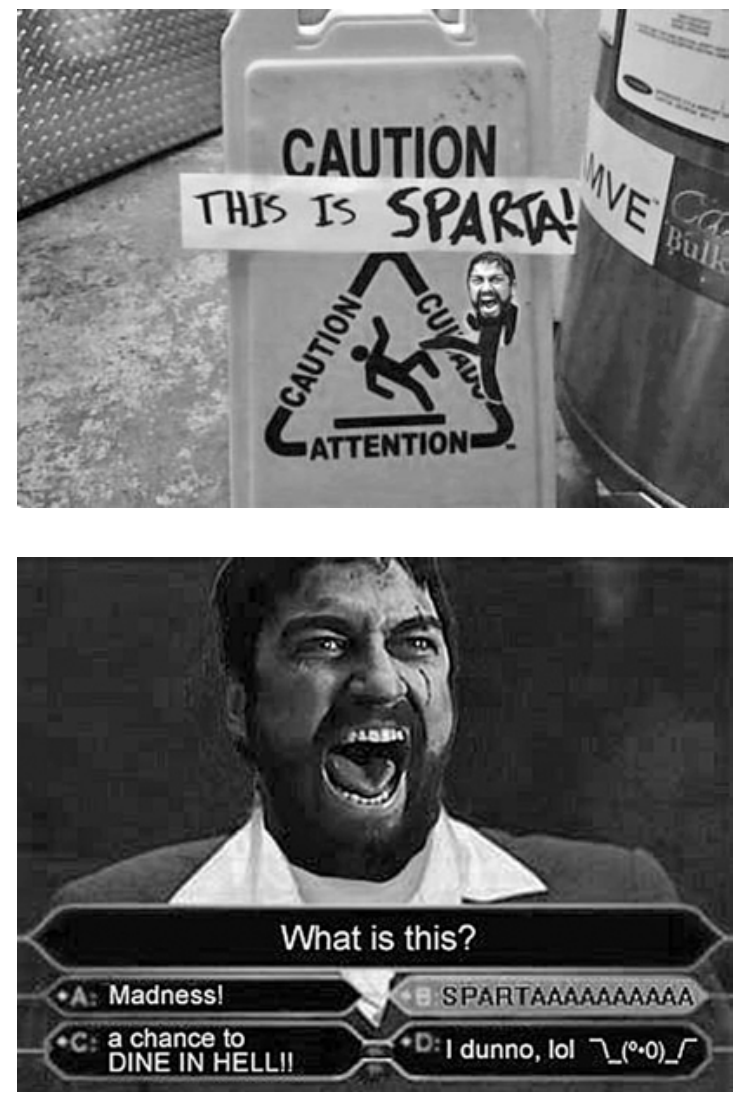

In my opinion, the pit scene provides a key to understanding why spoofs of 300 have become so crucial, as Snyder's vision of Sparta renegotiates the dimensions of rationality and irrationality. Today, as in ancient Greece diplomatic immunity is a fundamental principle and absolutely sacrosanct. In fact, in Herodotus' version of the events preceding the battle at Thermopylae, the Spartans acknowledge their sacrilege and send two volunteers of noble birth to die at the hands of Xerxes in requital for the slaying of his

12 Both images recur on numerous websites, thus tracing the original poster or the owner of any rights which may subsist in them proved impossible. I apologize for the infringement of any legal rights. 
heralds (cf. Herodotus, Histories 7.134.2) ${ }^{13}$ In 300, however, Leonidas' exclamation »This is Sparta!« overrides all rules and traditions grounded in political and humanitarian reason. It claims the Spartan kósmos as a sphere unto itself, with its own interior logic and hermeneutic rationality. Killing the emissaries severs all ties with the common Greek world and henceforth, all Spartan actions follow this particular interior logic which culminates in the warriors' self-sacrifice on the battlefield.

In the pit scene, the audience is also confronted with a process of othering: the Persian envoys are turned into a scapegoated other bent on exterminating the Spartan kósmos through abominable acts of violence. They are objectified as ruthless minions to a barbaric king who may rightfully and reasonably be denied the basic rights of all emissaries. Yet in doing so, the Spartans also install themselves as an alterity, spurning rational considerations and social traditions. Therefore, the pit scene is the point of no return, both for the plot and the audience's frame of mind. Setting the tone of the discourse for all actions and decisions from that point on, it establishes the resort to violence and self-sacrifice as a diktat of reason.

\section{Conclusion}

I would argue that the need to ridicule the message conveyed in 300 is based on more than a lingering sense of unease about an unreasonable, emotional and subconscious reaction: it springs from the fact that 300 fails to provide a solid, resilient reference system for the hetero-normative and hyperviolent standards it conveys. The experience of war is no longer an integral element of wide parts of contemporary Western civilization. When ancient writers related anecdotes about the Spartans' laconic wit, they were raising their hat to kindred souls deserving praise and admiration for their repartee in humiliating barbarian enemies through para prosdokian rhetoric. In the mock parodies of 300, however, it becomes clear that even though Spartan valor and defiance of death have the potential to capture the audience and send shivers down their spines, the reality of war and its consequences remain an alien experience. On screen, violence and death can be valued for their fear factor

13 Herodotus also relates Xerxes' reaction to the Spartan attempt at atonement: even though the Spartans had made havoc of all laws and traditions, the Persian king refuses to copy their action or to free them from their guilt by killing the Spartan volunteers (cf. Herodotus, Histories, 7.136.2). 
and their aesthetic merit, allowing a brief holiday from reason. Yet when the cinematic world intersects too closely with everyday reality, the artistic threat of pain and self-sacrifice becomes real and starts to imply consequences for the audience's personal lives, e.g. losing their right to autonomy and individuality. Therefore the mocking and parodying of 300 as an example of existential struggle also addresses the very substantial angst which arises from its references to today's great chimera, the War on Terror. 300 celebrates monolithic gender norms and clings to the ideal of an archaic masculinity, the abandonment of the individual self in favor of the common good, defiance in the face of death and the acceptance of war as an end in itself. These are ideals which are now widely associated with a past we have abandoned, a past with strong connotations of totalitarian regimes and their regimentation and control of the minds and behavior of their populations. Therefore, even in the age of War on Terror, when the motive of a fight for freedom and heroic imagery and rhetoric very similar to that of 300 have become a daily reality, we are not ready to welcome their return.

Ridiculing the depiction of the Spartan stand in 300 is also a cathartic reaction to a situation of intense unease caused by a conflict between reason and intellect and a rather primal set of emotions and instincts. In the parodies of 300 , humour acts as a stress-reliever, counteracting the inner conflict and existential angst the film evokes. While our minds are firmly rooted in modern or postmodern discourse, we still seem to crave an emotionally charged experience of raw immediacy, which may easily be projected into the premodern period and provides us with a rush of adrenaline which then leaves us feeling tainted. It is this guilt about longing for something reason tells us is wrong that has us calling for comic relief, ridiculing what we are afraid to deal with. Puns, parodies and laughter have the ability to right what is wrong, allowing us to come to terms with our conflicting emotions from fascination to repulsion. Both the spontaneous mocking of catchphrases like »This is Sparta! « and the large-scale but crude parodies such as Meet the Spartans or $» \mathrm{D}$-Yikes $«$ deliberately create scenarios where aestheticized violence, existential fear and liminal experiences are reduced to absurdity. The crudeness of these parodies is due to the need for an incongruence experience, which Kant and Freud both established to be one of the underlying categories of humour (cf. Freud 1905/1982: 9-22, 176-177). The parodies defy the value of aestheticized violence, heroism and artfully staged fights to the death, targeting in particular the ideal of a belligerent archaic masculinity and hetero-normativity and the abandonment of individuality. Thus, incongruity is explicitly made manifest and facilitates an emotional release (cf. 
Kant 1951 [1790]: 172). Parodies of 300 and the Spartans' ultimate struggle for freedom dissipate the fear of war as an all-encompassing entity that eats up all the certainties of reason, the social beliefs formed over many decades and finally the essence of the individual and its right to preserve the integrity of body and mind.

\section{LITERATURE}

Adorno, Theodor W./Max Horkheimer (1947): Dialektik der Aufklärung, Amsterdam: Querido.

Afrasiabi, Kaveh L. (2007): »Persians and Greeks: Hollywood and the Clash of Civilisations «. In: Global Dialogue 9.1-2, 96-104.

Cartledge, Paul (2007): Thermopylae: the Battle that Changed the World, New York: Vintage Books.

Cartledge, Paul (2007): »Another view«. In: The Guardian 2 April, 25.

Coetzee, Olga/Frans Cilliers (2012): »Humour as defence against the anxiety manifesting in diversity experiences «. In: SA Journal of Industrial Psychology/SA Tydskrif vir Bedryfsielkunde 38.2, 1-9, (<http://dx.doi.org./10. 4102/sajip.v38i2.990>). Accessed 12 February 2013.

Ducat, Jean (2006): Spartan Education: Youth and Society in the Classical Period, Swansea: Classical Press of Wales.

Emig, Rainer (2001): Krieg als Metapher im zwanzigsten Jahrhundert, Stuttgart: Neil McBeath.

Es, Murat (2011): »Frank Miller's 300: Civilizational Exclusivism and The Spatialized Politics of Spectatorship«. In: Aether: The Journal of Media Geography, 6-39.

Freud, Sigmund (1982 [1905]): Der Witz und sein Beziehung zum Unbewußten. Studienausgabe. Band IV, Frankfurt am Main: Fischer.

Grossman, Lev (2007): »The Art of War«. In: Time 169.11, 58-61.

Horlacher, Stefan (2009): »A Short Introduction to Theories of Humour, the Comic, and Laughter«. In: Gaby Pailer/Andreas Böhn/Ulrich Scheck (eds.): Gender and Laughter. Comic Affirmation and Subversion in Traditional and Modern Media, Amsterdam/New York: Rodopi, 17-47.

Kant, Immanuel (1951 [1790]): Critique of Judgement, New York: Hafner Publishing Company.

Morreall, John (1983): Taking Laughter Seriously, Albany: State University of New York Press. 
Murray, Gabrielle (2004): This Wounded Cinema, This Wounded Life. Violence and Utopia in the Films of Sam Peckinpah, Westport: Praeger.

Szemler, George J./William J. Cherf/John C. Kraft (1996): Thermopylai. Myth and Reality in 480 B.C., Chicago: Ares Publishers.

Tasker, Yvonne (1993): Spectacular Bodies: Gender, Genre and the Action Cinema, London/New York: Routledge.

Thompson, Anne (2007): »Pic's Payoff Reps Tech Triumph«. In: Variety 406/5, 6-7.

Virilio, Paul (2003): Art and Fear, London: Continuum.

van Wees, Hans (2006): ") The Oath of the Sworn Bands $\measuredangle$ The Acharnae Stela, The Oath of Plataea and Archaic Spartan Warfare «. In: Andreas Luther et al. (eds.): Das frühe Sparta, Stuttgart: Steiner, 125-164.

Wertheimer, Jürgen (1986): Ästhetik der Gewalt: ihre Darstellung in Literatur und Kunst, Frankfurt am Main: Athenäum.

\section{FILMS}

300 (USA 2007, Director: Zack Snyder).

South Park, »D-Yikes« (USA 2007, Director: Trey Parker).

Meet the Spartans (Canada, USA 2008, Directors: Jason Friedberg, Aaron

Seltzer. 



\section{Authors and Editors}

Elisabeth Cheauré is Professor of Slavic Literature at the University of Freiburg and has an additional venia legendi in Gender Studies. She is also Honorary Professor at Tver' State University (Russia). Her current research interests include questions of national identity formation in Russia (especially gender aspects), the Russian reception of Napoleon, cultures of leisure in Russia, German-Russian cultural transfer and the history of science in Bulgaria.

Sabrina Feickert is a $\mathrm{PhD}$ student in Classical Studies and scholarship holder of the graduate research group »Friends, Patrons, Clients « at the University of Freiburg. As an associate member of the research group »Popular Cultures of History « she is working on a project about the popularization of history and archaeology in Scotland. Her research interests range across the fields of archaeology and history during Roman and Medieval times.

Axel Heimsoth is a historian and works as a research assistant at the Ruhr Museum, Essen. His main research interests are Westphalian transport history, the Ruhr in the Napoleonic era, the history of the Krupp family and the railway system in the Middle East. He is working on the exhibition project »1914 - Mitten in Europa« for the hundredth anniversary of the start of World War I.

Lesley Milne is Professor Emerita in the Department of Russian and Slavonic Studies (School of Cultures, Languages and Area Studies) at the University of Nottingham. Her current research project is a study of the ways in which laughter was mobilised during the First World War in the leading satirical/humorous journals of Britain, France, Germany and Russia.

Regine Nohejl is a Slavicist and historian of Eastern Europe. She works in the Slavic Studies Department at the University of Freiburg; currently as part of the research project »Napoleon, Borodino und der Vaterländische Krieg von 1812. Geschichtspopularisierungen im Kontext nationaler Identitätsfindung in Russland.«Her research focuses on $19^{\text {th }}$ century Russian cultural and intellectual history as well as the relevance of Gender Studies for understanding processes of identity formation in Eastern Europe. 
Louisa Reichstetter studied Modern History, Romance Studies and Anthropology at the Friedrich-Schiller-University Jena, where she is currently a $\mathrm{PhD}$ student working on the satiric press in Spain, France and Germany during the interwar period. In addition to writing her doctoral thesis, she works as a freelance journalist and photographer for among others the German weekly Die Zeit in Hamburg. She has published an article on the development of Jena's free student press in the early 1990s in an edited volume on the history of the university as well as extensive oral history interviews in books by the Thuringian Political Education Authority and book reviews for Sehepunkte, H-Soz-u-Kult and Die Zeit.

Jonathan Waterlow is a British Academy Postdoctoral Fellow in History at St Antony's College, University of Oxford. His doctoral work focused on ordinary Soviet citizens' humour in Stalin's 1930s; he is currently revising this for publication. His new research project is entitled »The Soviet Nuremberg: Forging the Postwar World Beyond the Iron Curtain, 1945-53«. 